\author{
UNIVERSIDADE DE SÃO PAULO \\ ESCOLA DE ENGENHARIA DE LORENA
}

ANA PAULA ALMEIDA DOS SANTOS

\title{
DESENVOLVIMENTO DE UM MÉTODO PARA A DETERMINAÇÃO DA ATIVIDADE DE ESTERASES USANDO MATERIAL LIGNOCELULÓSICO COMO SUBSTRATO
}





\title{
DESENVOLVIMENTO DE UM MÉTODO PARA A DETERMINAÇÃO DA ATIVIDADE DE ESTERASES USANDO MATERIAL LIGNOCELULÓSICO COMO SUBSTRATO
}

\begin{abstract}
Dissertação apresentada à Escola de Engenharia de Lorena da Universidade de São Paulo para obtenção do título de Mestre em Ciências do Programa de Pós-graduação em Biotecnologia Industrial na área de Microbiologia Aplicada
\end{abstract}

Orientador: Prof. Dr. André Luis Ferraz

Edição reimpressa e corrigida

Lorena-SP

Outubro, 2014 


\section{AUTORIZO A REPRODUÇÃO E DIVULGAÇÃO TOTAL OU PARCIAL DESTE TRABALHO, POR QUALQUER MEIO CONVENCIONAL OU ELETRÔNICO, PARA FINS DE ESTUDO E PESQUISA, DESDE QUE CITADA A FONTE.}

Catalogação na Publicação

Biblioteca "Cel. Luiz Sylvio Teixeira Leite"

Escola de Engenharia de Lorena da Universidade de São Paulo

Santos, Ana Paula Almeida dos

Desenvolvimento de um método para a determinação da atividade de esterases usando material lignocelulósico como substrato. / Ana Paula Almeida dos Santos. - ed. reimpr., corr. -2014.

87 p.: il.

Dissertação (Mestre em Ciências - Programa de Pós-Graduação em Biotecnologia Industrial na Área de Microbiologia Aplicada) - Escola de Engenharia de Lorena da Universidade de São Paulo. 2014.

Orientador: André Luis Ferraz

1. Ácido ferúlico 2. Biomassa 3. Cana-de-açúcar 4. Feruloil esterase 5. Hidrólise enzimática. I. Título. II. Ferraz, André Luis, orient. 
Dedico esse trabalho ao meu irmão André Luiz com muito amor por todos os seus ensinamentos em vida.

“...E sem que se perceba, a gente se encontra pra uma outra folia..."

(Oswaldo Montenegro) 



\section{AGRADECIMENTOS}

Em primeiro lugar agradeço à minha família por acreditar em mim. Minha mãe, pai e irmã por todo o apoio. Agradeço especialmente ao meu irmão André Luiz que mesmo em outro plano cuida de mim.

Ao meu orientador André Ferraz por toda a paciência e dedicação e pelos ensinamentos durante esses anos.

À Escola de Engenharia de Lorena por fazer possível minha participação no programa de Biotecnologia Industrial.

Ao técnico do Laboratório José Moreira pelos sábios conselhos.

Aos colegas do Laboratório de Ciência da Madeira: Dayelle, Fernanda, Maria Fernanda, Omar, Fernando, Thales, Angela, e Vitor pela companhia e por me ajudarem quando precisei.

Ao José Cobrinha pelo café e ajuda no laboratório.

Aos professores do Departamento de Biotecnologia Industrial pelos conhecimentos a mim transmitidos.

A todos os meus amigos por todo o carinho.

À CAPES, CNPQ e FAPESP pelo apoio financeiro e à USP por tornar esse trabalho possível. 

A persistência é o melhor caminho para o êxito.

(Charles Chaplin) 



\section{RESUMO}

SANTOS, A. P. A. Desenvolvimento de um método para a determinação da atividade de esterases usando material lignocelulósico como substrato. 2014. 87p. Dissertação (Mestrado em Ciências) - Escola de Engenharia de Lorena, Universidade de São Paulo, Lorena, 2014.

As feruloil esterases são enzimas relevantes para o processo de hidrólise de materiais lignocelulósicos oriundos de gramíneas. Estas enzimas são tradicionalmente determinadas com o emprego de substratos sintéticos de baixa massa molar. Entretanto, as atividades determinadas a partir desses ensaios não se correlacionam adequadamente com a ação das enzimas em substratos complexos e insolúveis como os materiais lignocelulósicos. Neste sentido, o presente trabalho visou desenvolver um método apropriado para medir a atividade de feruloil esterases utilizando um material lignocelulósico como substrato. Para isso, as medulas de híbridos de cana-de-açúcar com baixo teor de lignina e de um cultivar de referência com elevado teor de lignina foram usadas para preparar substratos de baixa recalcitrância usados na determinação da atividade de feruloil esterases de 3 origens diferentes. As medulas foram extraídas com água para remoção de sacarose e posteriormente analisadas quanto à composição química. As medulas foram ainda submetidas a uma etapa de pré-hidrólise com celulase comercial por 4 horas para preparar um substrato menos recalcitrante e adequado para a ação das enzimas. Após a avaliação do efeito da carga de feruloil esterases na cinética de hidrólise dos ésteres de ácido ferúlico, foi definido que os ensaios enzimáticos deveriam ser realizados com um tempo fixo de 5 minutos a fim de determinar a atividade numa faixa de conversão dos ésteres que fosse da ordem de $2 \%$, assegurando a determinação na região de velocidade máxima de reação. Idealmente, o método foi desenhado para empregar diluições da enzima que gerassem dados de conversão levemente menores e maiores do que $2 \%$ de conversão, o que permitiu a determinação exata da carga de enzima necessária para converter $2 \%$ de éster do ácido ferúlico em ácido após 5 min de reação por interpolação de dados. As condições de reação foram fixadas em $40^{\circ} \mathrm{C}$ e pH 6,3. Os níveis de atividade e as reprodutibilidades experimentais determinadas para as 3 enzimas se mostraram dependentes do substrato, principalmente associadas ao teor inicial de lignina observado nas medulas in natura. Tomando as determinações de atividade da feruloil esterase de rúmen como exemplo, os dados obtidos, expressos em UI/ $\mu$ de proteína, foram: 2,3 \pm 0,2, 2,0 \pm 0,8 e 0,6 \pm 0,5 , respectivamente para os substratos oriundos das medulas que continham originalmente $13,0 \pm 0,3,12,8 \pm 0,5$ e 19,1 $\pm 0,1 \%$ de lignina. Empregando os substratos oriundos de medulas com baixo teor de lignina original, o método se mostrou adequado para estudar os efeitos de variáveis como temperatura e $\mathrm{pH}$ do meio reacional sobre a atividade enzimática. No caso da feruloil esterase de rúmen, os estudos mostraram uma temperatura ótima de reação de $40^{\circ} \mathrm{C}$ e atividades crescentes em função do pH, com máximo na região de 6,3 a 7,2. Pode-se concluir que o trabalho permitiu a elaboração de uma metodologia adequada para a determinação de feruloil esterases empregando um substrato lignocelulósico, desde que este substrato seja preparado a partir de medulas de cana com baixa recalcitrância decorrente do baixo teor original de lignina.

Palavras-chave: Ácido ferúlico. Biomassa. Cana de açúcar. Feruloil esterase. Hidrólise enzimática. 


\begin{abstract}
SANTOS, A. P. A. Development of a method to determine the activity of esterases using a lignocellulosic material as a substract. 2014. 87p. Dissertation (Master of Science) - Escola de Engenharia de Lorena, Universidade de São Paulo, Lorena, 2014.
\end{abstract}

Feruloyl esterases are important enzymes acting on the hydrolysis of lignocellulosic materials from grasses. These enzymes are traditionally determined using synthetic low molar mass substrates. However, the activities determined through these assays do not correlate with the action of the enzymes on complex and insoluble substrates such as lignocellulosic materials. According to this, the present work aimed to develop an appropriate method to measure feruloyl esterase activities using a lignocellulosic material as substrate. Pith regions, recovered from low lignin content sugarcane hybrids and from a high lignin content reference cultivar, were used to prepare low recalcitrance lignocellulosic substrates, used to determine the activity of 3 different feruloyl esterases. The pith samples were extracted with water to remove sucrose and then analyzed concerning its chemical composition. They were further subjected to a prehydrolysis step with commercial cellulase for 4 hours to prepare a less recalcitrant and proper substrates for the action of the feruloyl esterases. After evaluating the effect of enzyme loading on the hydrolysis kinetics of the ferulic acid esters, it was defined that the enzymatic assays should be done at a fixed time of 5 minutes, in order to determine the enzymatic activity in the region of maximal hydrolysis rate. Ideally, the method was designed to use enzyme dilutions that provide ferulic acid ester conversions in the range of $2 \%$, which allowed the exact determination of the enzyme load necessary to convert $2 \%$ of ferulic acid ester in acid after 5 minutes of reaction by interpolating data. The reaction conditions were fixed at $40^{\circ} \mathrm{C}$ and $\mathrm{pH} 6.3$. The activity levels and the experimental reproducibility determined for the 3 enzymes showed to be dependent of the substrate, specially associated with the initial lignin content of each material. Taking the rumen feruloyl esterase activities as example, the data obtained in $\mathrm{UI} / \mu \mathrm{g}$ of protein were $2.3 \pm$ $0.2,2.0 \pm 0.8$ e $0.6 \pm 0.5$, respectively for the substrates from sugarcane piths containing $13.0 \pm 0.3,12.8 \pm 0.5$ and $19.1 \pm 0.1 \%$ of lignin. Employing the substrates with low lignin contents, the method showed to be appropriate to study the effects of variables such as the reaction temperature and $\mathrm{pH}$ on the enzymatic activity. For rumen feruloyl esterase, the studies showed optimum temperature at $40^{\circ} \mathrm{C}$ and increasing activities for increasingly $\mathrm{pHs}$, with the maximum in the range 6.3-7.2. In conclusion, the work provided a proper methodology to determine feruloyl esterase activity using a lignocellulosic substrate, but the substrate needs to be prepared from a non-recalcitrance sugarcane pith that was observed in samples with low initial lignin content.

Keywords: Ferulic acid. Biomass. Sugarcane. Feruloyl esterase. Enzymatic hydrolysis. 


\section{LISTA DE FIGURAS}

Figura 1- Padrão de ligação de hidrogênio mais provável na celulose. ................19 Figura 2- Unidade de celulose I de acordo com o modelo de Meyer-Misch -

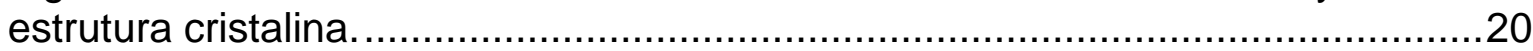

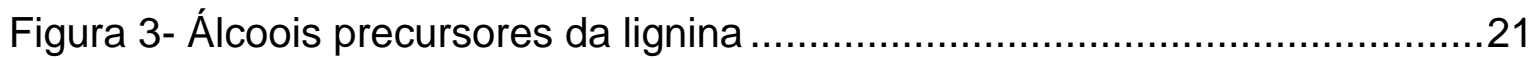

Figura 4- Estrutura sugerida de lignina de madeira de folhosas. .......................21

Figura 5- Ligação $\alpha$ - éter entre lignina e hidroxinamatos. .................................22

Figura 6- Hemiceluloses caracterizadas por ligação $\beta-(1 \rightarrow 4)$ com configuração

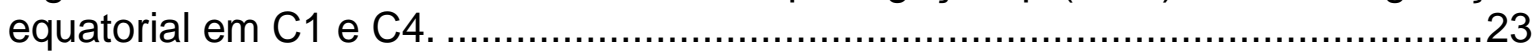

Figura 7- Esquema de xilana de caule de milho. ..........................................25

Figura 8- Diagrama esquemático mostrando as possíveis ligações cruzadas entre lignina e polissacarídeos. a) ligação éster direta; b) ligação éter direta; c) ácido hidroxicinâmico esterificado a polissacarídeos; d) ácido hidroxicinâmico esterificado à lignina; e) ácido hidroxicinâmico eterificado à lignina; f) ponte de ácido ferúlico éster-éter; g) ponte di-éster de ácido dihidro diferúlico; h) ponte diéster-éter de ácido dihidro diferúlico ........................................................27

Figura 9- Possíveis ligações entre lignina e ácidos hidroxicinâmicos. .................28

Figura 10- Ligação éster entre ácido p-cumárico e lignina..................................29 Figura 11- Estrutura do ácido 2-propenóico,3-(4-hidroxi-3-metoxifenil) (ácido

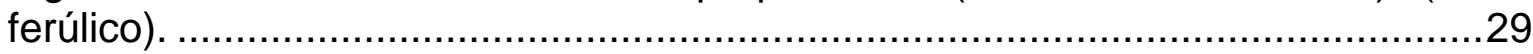

Figura 12- Estrutura molecular do ácido p-cumárico.....................................30 Figura 13- Reações catalizadas pelas polissacarídeo monooxigenases (PMOs) e

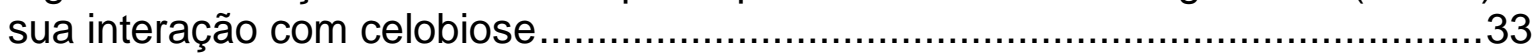

Figura 14- Especificidade do substrato em algumas hemicelulases. ....................35

Figura 15- Hidrólise de alguns metil ésteres por esterases ..............................36

Figura 16- Mecanismo de ação de acetil xilana esterase utilizando uma sequência serina, histidina e asparagina (Ser-His-Asp) como catalizador da reação. ...........40 Figura 17- Mecanismo de ação de acetil xilana esterases que envolvem a participação de metais. ................................................................................ 40

Figura 18- As quatro frações da cana-de-açúcar separadas. A) Fração externa; B) Córtex; C) Interface medula-córtex; D) Medula...................................................43 Figura 19- Conversão enzimática da celulose em diferentes frações do entrenó da cana híbrida. A) Híbrido 58; B) Híbrido 89 ..................................................45 Figura 20- Cromatogramas do hidrolisado de um substrato preparado a partir da medula do híbrido de cana 58. A hidrólise ilustrada empregou E-FAE-RU numa carga de enzima equivalente a $25 \mu \mathrm{g}$ de proteínas/g de substrato após 2 horas de reação.

Figura 21 - Formação de ácido ferúlico durante o tratamento dos substratos com feruloil esterase de rúmen por tempos de reação de até $48 \mathrm{~h}$. As figuras foram divididas em tempos curtos (até $120 \mathrm{~min}$ ) e longos (até 48h) de reação para melhor visualização da cinética de hidrólise. Substratos preparados a partir das medulas dos híbridos 58 (A) e 89 (B)....

Figura 22- Formação de ácido ferúlico durante o tratamento do substrato preparado a partir do híbrido $58 \mathrm{com}$ feruloil esterase de Clostridium thermocellum por tempos de reação de até $48 \mathrm{~h}$. As figuras foram divididas em tempos curtos (até $120 \mathrm{~min}$ ) e longos (até $48 \mathrm{~h}$ ) de reação para melhor visualização da cinética de hidrólise. 
Figura 23- Comparação da hidrólise enzimática dos substratos 58 (A) e 89 (B) na ausência e na presença de BSA $(1 \mathrm{mg} / \mathrm{mL})$. .............................................. 64

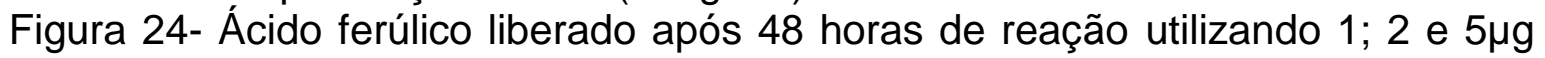

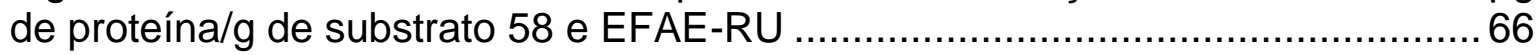

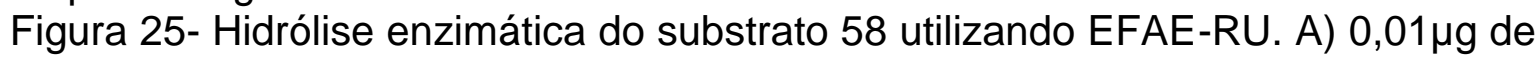
proteína/grama de substrato B) $0,05 \mu \mathrm{g}$ de proteína/grama de substrato C) $0,1 \mu \mathrm{g}$ de proteína/grama de substrato D) 0,5 $\mathrm{gg}$ de proteína/grama de substrato. ...........67 Figura 26- Comparação entre os métodos de parada de reação enzimática utilizando diferentes cargas de EFAE-RU ( 0,$01 ; 0,025 ; 0,05$ e $0,075 \mu \mathrm{g}$ de

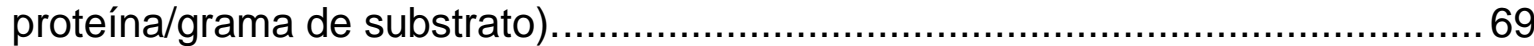
Figura 27- Solução padrão de ácido ferúlico em duas concentrações diferentes submetida à aquecimento e tratamento com ácido acético ................................70 Figura 28- Exemplificação de como a atividade da enzima EFAE-RU foi calculada. Gráfico em função da \% de ácido ferúlico liberado versus log da carga enzimática em $\mu \mathrm{g}$ de proteína/kg de substrato. ........................................................... 72 Figura 29- Atividades enzimáticas de três feruloil estereases expressas em $\mathrm{Ul} / \mu \mathrm{g}$ de proteína determinadas a partir do emprego de diferentes substratos. A) Enzima EFAE-RU; B) Enzima FAEA; C) Enzima EFAEZCT. ...................................... 74 Figura 30- Atividade de EFAE-RU em diferentes temperaturas de reação............ 75 Figura 31- Atividade de EFAE-RU em diferentes pHs: 4,5; 5,5; 6,3 e 7,2 utilizando os substratos A)58, B) 89 e C) RB............................................................ 76 


\section{LISTA DE TABELAS}

Tabela 1- Principais tipos de polissacarídeos presentes nos diferentes tipos de

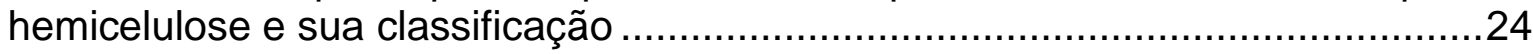
Tabela 2- Enzimas envolvidas na hidrólise de heteroarabinoxilanas complexas. .34 Tabela 3- Classificação das feruloil esterases.

Tabela 4- Propriedades biofísico-químicas das feruloil esterases (FAEs). ...........38 Tabela 5- Composição química das diversas frações do entrenó dos híbridos 58, 89 e do cultivar de referência $(\% \mathrm{~m} / \mathrm{m})$. 44 Tabela 6- Composição química da medula de entrenós de diferentes híbridos de cana de açúcar (\%, m componente/m medula, base seca).

Tabela 7- Composição de ácidos hidroxicinâmicos da medula de entrenós de diferentes híbridos de cana de açúcar (\%, m componente/m medula, base seca).

Tabela 8- Composição química dos sólidos resultantes da digestão com celulases da medula de entrenós de diferentes híbridos de cana de açúcar $(\%, \mathrm{~m}$ componente/m medula, base seca).

Tabela 9- Teor de ácidos hidroxicinâmicos nos sólidos resultantes da digestão com celulases da medula de entrenós de diferentes híbridos de cana de açúcar (\%, $\mathrm{m}$ componente/m medula, base seca).

Tabela 10- Balanço de massas para o processo de digestão da medula com celulases comerciais.

Tabela 11- Dados das atividades presentes na celulase comercial empregada na digestão da medula (PESSOTI, 2013). 59

Tabela 12- Reação de 5 minutos usando EFAE-RU e substrato 89. 69 Tabela 13- Atividades de diferentes feruloil esterases $(\mathrm{Ul} / \mathrm{ml})$ obtidas a partir de ensaios realizados com os substratos 58,89 e RB. 72 Tabela 14- Atividades específicas de diferentes feruloil esterases (UI/ $\mu \mathrm{g}$ de proteína) obtidas a partir de ensaios realizados com os substratos 58,89 e RB..73 


\section{SIGLAS E ABREVIAÇÕES}

AF- Ácido ferúlico

AC- Ácido cumárico

EFAERU- Feruloil esterase de rúmen

EFAEZCT- Feruloil esterase de Clostridium thermocellum

FAEA- Feruloil esterase do tipo $\mathrm{A}$

UI - $\mu$ mol de produto liberado por minuto nas condições de ensaio.

HPLC - High Performance Liquid Chromatography

BSA - Albumina sérica bovina 


\section{SUMÁRIO}

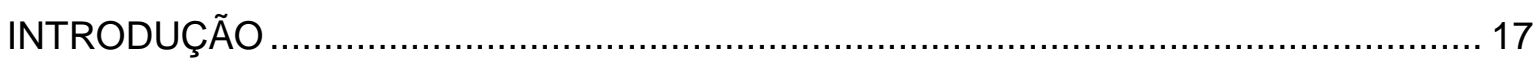

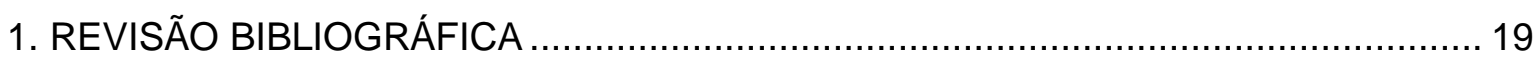

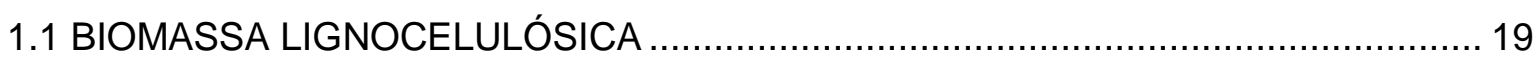

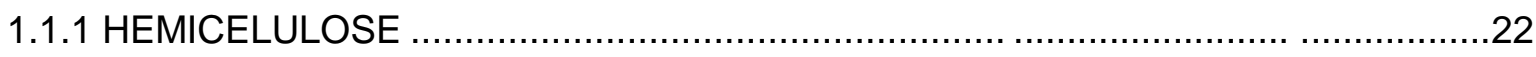

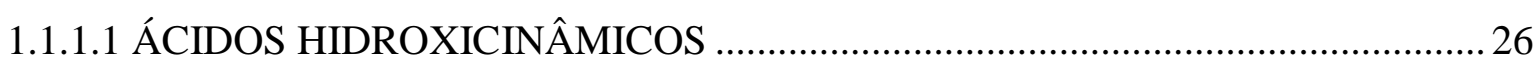

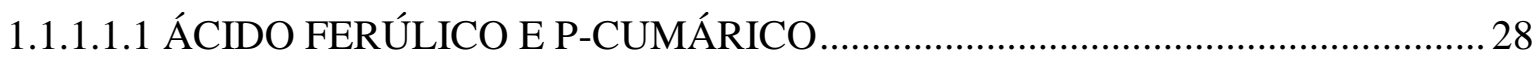

1.2 HIDRÓLISE ENZIMÁTICA DOS MATERIAIS LIGNOCELULÓSICOS ......................... 30

1.2.1 ENZIMAS ENVOLVIDAS NA DEGRADAÇÃO DA PAREDE CELULAR VEGETAL 31

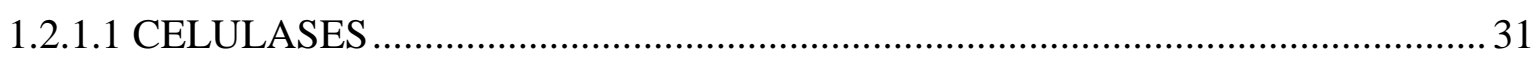

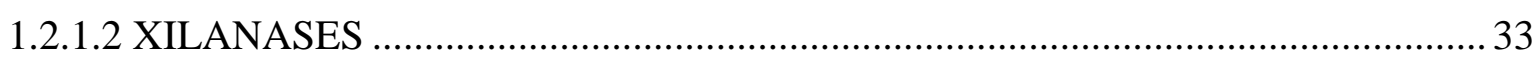

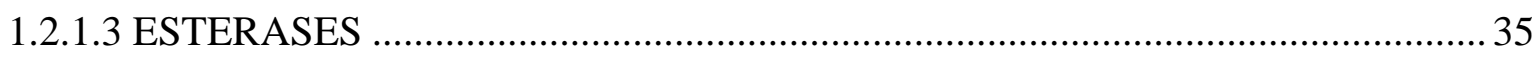

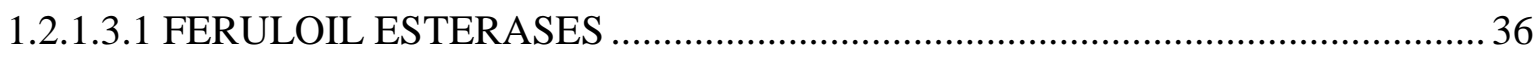

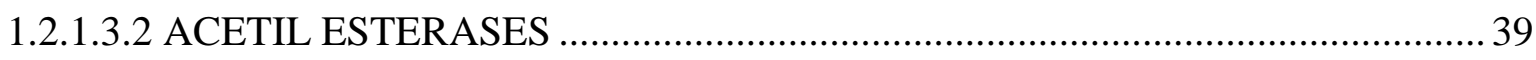

1.2.1.3.3 MÉTODOS DE DETERMINAÇÃO DA ATIVIDADE DE ESTERASES.......... 41

1.3 AMOSTRAS DE CANA-DE-AÇÚCAR E CARACTERÍSTICAS PREVIAMENTE

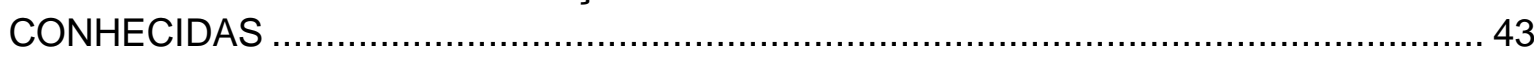

1.4 CONSIDERAÇÕES FINAIS SOBRE A REVISÃO BIBLIOGRÁFICA …..................... 45

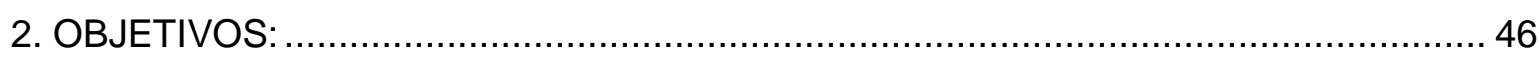

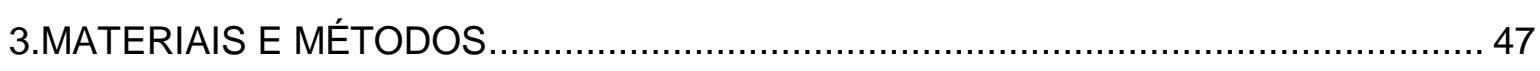

3.1 AMOSTRAS DE CANA DE AÇÚCAR E PREPARO DA MEDULA ...........................47

3.2 PREPARO DO SUBSTRATO POR DIGESTÃO DA MEDULA COM CELULASES

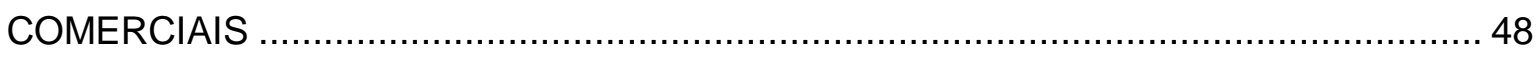

3.3 DETERMINAÇÃO DA COMPOSIÇÃO QUÍMICA DAS AMOSTRAS …..................... 48

3.3.1 DETERMINAÇÃO DE POLISSACARÍDEOS E LIGNINA ......................................... 48

3.3.2 DETERMINAÇÃO DE ÁCIDOS HIDROXICINÂMICOS ........................................ 49

3.4 REAÇÕES DE HIDRÓLISE DOS SUBSTRATOS COM ESTERASES ....................... 50

3.4.1 AJUSTE DO MÉTODO DE HIDRÓLISE DO SUBSTRATO COM ESTERASES..... 51

3.5 DEFINIÇÃO DE UM PROTOCOLO GERAL PARA A DETERMINAÇÃO DA ATIVIDADE ENZIMÁTICA DE FERULOIL ESTERASES.......................................... 52

3.6 INFLUÊNCIA DO pH E TEMPERATURA NA CONVERSÃO DO SUBSTRATO .........53

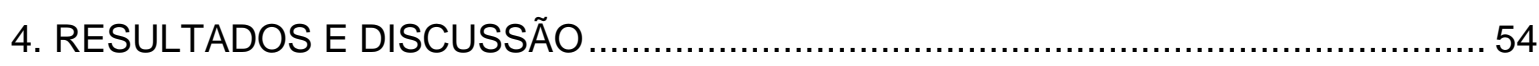

4.1 COMPOSIÇÃO QUÍMICA DA MEDULA DOS ENTRENÓS DE CANA DE AÇÚCAR. 54 4.2 DIGESTÃO DA MEDULA COM CELULASES E PREPARO DE UM SUBSTRATO ADEQUADO À DETERMINAÇÃO DA ATIVIDADE DE ESTERASES ……………........56 4.3 HIDRÓLISE DO SUBSTRATO ORIUNDO DA MEDULA DE CANA- DE- AÇÚCAR COM FERULOIL ESTERASES 
4.4. AJUSTE DO MÉTODO PARA DETERMINAÇÃO DA ATIVIDADE DE FERULOIL ESTERASES

4.4.1 TESTES DE PARADA DE REAÇÃO COM AQUECIMENTO EM BANHO EM EBULIÇÃO OU POR ADIÇÃO DE ÁCIDO ACÉTICO AO MEIO REACIONAL 68

4.5 ENSAIOS ENZIMÁTICOS

4.6 EMPREGO DO MÉTODO DESENVOLVIDO PARA AVALIAR A INFLUÊNCIA DA TEMPERATURA E $\mathrm{PH}$ NA ATIVIDADE DAS ENZIMAS ESTUDADAS .75

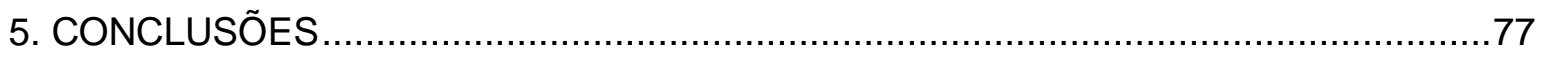

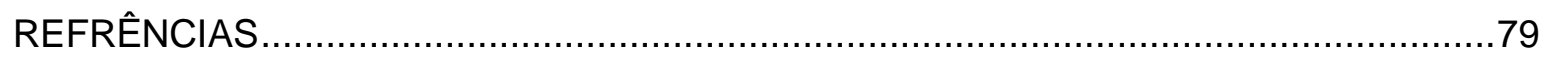




\section{INTRODUÇÃO}

Polissacarídeos de parede celular de plantas são degradados por microorganismos desde que eles produzam as enzimas e outros metabólitos extracelulares necessários. A natureza das interações entre enzima e substrato e o sinergismo entre diversas enzimas é assunto de diversas pesquisas, principalmente com relação à despolimerização de celulose e hemicelulose (JACOBSEN; WYMAN, 2000; LEVASSEUR et al, 2013). A conversão de celulose em glicose seria uma ótima via para a produção de etanol e outros insumos químicos derivados da biomassa, porém há vários fatores limitantes a essa hidrólise como, por exemplo, a baixa porosidade da parede celular devido à presença de hemicelulose e lignina envolvendo a celulose, o que dificulta a ação de celulases. A lignina e a hemicelulose podem ser removidas através de prétratamentos, mas já se tem produzido plantas híbridas com baixos teores de lignina, o que levaria ao uso de pré-tratamentos mais brandos e menor alteração dos polissacarídeos (MASARIN et al., 2011). Uma limitação para a hidrólise enzimática da hemicelulose ocorre quando resíduos de açúcar estão esterificados a compostos fenólicos como ácido ferúlico e ácido p-cumárico. Esses ácidos fenólicos limitam a digestibilidade da parede celular e podem até ser tóxicos aos microorganismos envolvidos na biodegradação (ROSAZZA et. al., 1995). Também foi reportado que substituintes acetilados em xilana inibem a digestão de polissacarídeos de plantas por ruminantes, o que sugere que a desacetilação enzimática deve ser pré-requisito para a quebra de acetil xilana (BIELY; PULS; SCHNEIDER, 1985; YANG, et. al., 2009). Por outro lado, foram relatadas algumas espécies de microorganismos capazes de produzir esterases que clivam esses compostos fenólicos do açúcar deixando o resíduo de açúcar livre para o ataque hidrolítico de outras enzimas. Essas esterases já foram purificadas e parcialmente caracterizadas de vários micro-organismos como Streptomyces olivochromogenes (FAULDS; WILLIAMSON, 1991), Pseudomonas fluorescens, Penicillium pinophilum e vários Aspergillus sp. (FAULDS; WILLIAMSON, 1994). No entanto, a maioria dos estudos feitos até o momento para medir a atividade destas hidrolases emprega substratos sintéticos de característica não-lignocelulósica. 
Isso implica em um problema, pois a atividade de esterase obtida nem sempre corresponde à atividade ocorrida em substratos lignocelulósicos usualmente empregados em processos hidrolíticos.

Em estudos prévios de nosso próprio grupo de pesquisas foi analisada a recalcitrância de 4 porções da cana-de-açúcar: casca, córtex, interface córtexmedula e medula. A medula foi a porção que apresentou menor recalcitrância, isto é, maior susceptibilidade à hidrólise (SIQUEIRA, et. al., 2011; COSTA et al., 2013). Neste contexto, a medula de híbridos de cana-de-açúcar com teor baixo de lignina e de um cultivar de referência foi usada como substrato para avaliação da atividade de três feruloil esterases: feruloil esterase de rúmen (EFAE-RU); feruloil esterase purificada do tipo A (FAEA); e feruloil esterase de Clostridium thermocellum (EFAEZCT). Uma série de ensaios enzimáticos foi desenvolvida no sentido de identificar um procedimento experimental adequado para determinar as atividades destes complexos enzimáticos a partir do emprego da medula de cana como um substrato que pudesse simular substratos similares aos encontrados em processos de conversão enzimática de materiais lignocelulósicos. 


\section{REVISÃO BIBLIOGRÁFICA}

\subsection{BIOMASSA LIGNOCELULÓSICA}

A biomassa lignocelulósica é composta basicamente por celulose, hemicelulose e lignina. A celulose representa cerca de 50\% da massa dos materiais lignocelulósicos e é um homopolímero linear composto por monômeros de D-anidroglucopiranose que são ligados entre si por ligações glicosídicas do tipo $\beta-(1 \longrightarrow 4)$. Através de dados de difração de raio $X$, ressonância magnética nuclear (NMR) e infravermelho, foi concluído que, na celulose nativa - celulose I, existem ligações de hidrogênio intra e intermoleculares entre os oxigênios e hidrogênios indicados na Figura1 (O- 3-H e O-5'; O-2-H e O-6'). Essas ligações de hidrogênio criam uma estrutura cristalina rígida de celulose (Figura 2) que dificulta a sua degradação (KLEMM et. al., 1998).

Figura 1- Padrão de ligação de hidrogênio mais provável na celulose.
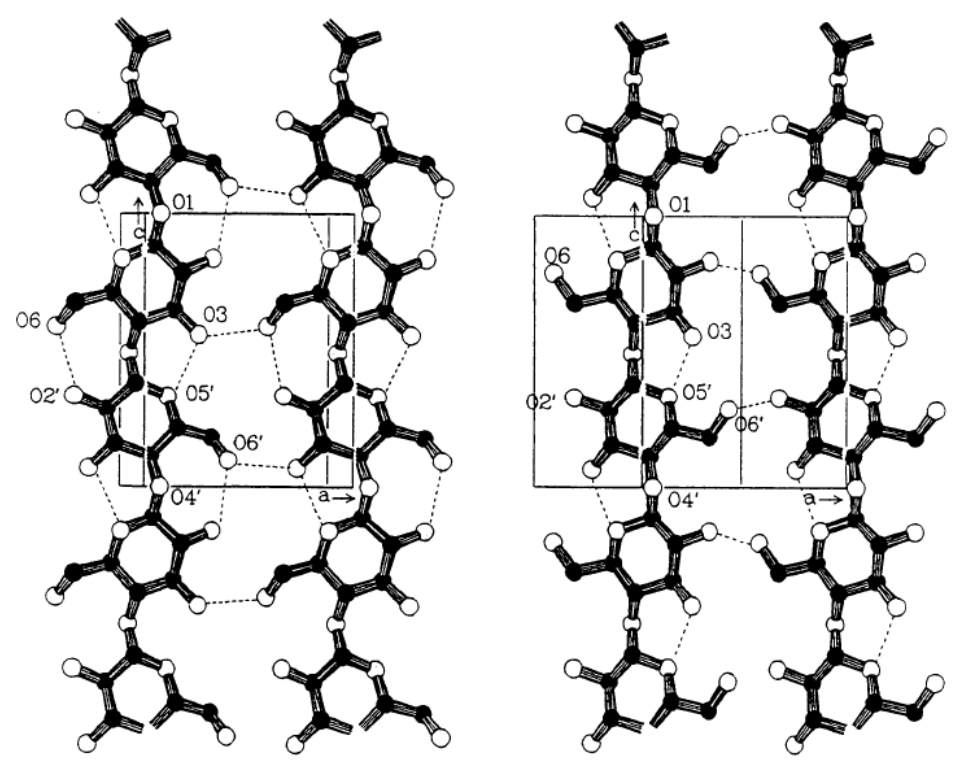

Fonte: (KLEMM et al., 1998) 
Figura 2- Unidade de celulose I de acordo com o modelo de Meyer-Misch - estrutura cristalina.

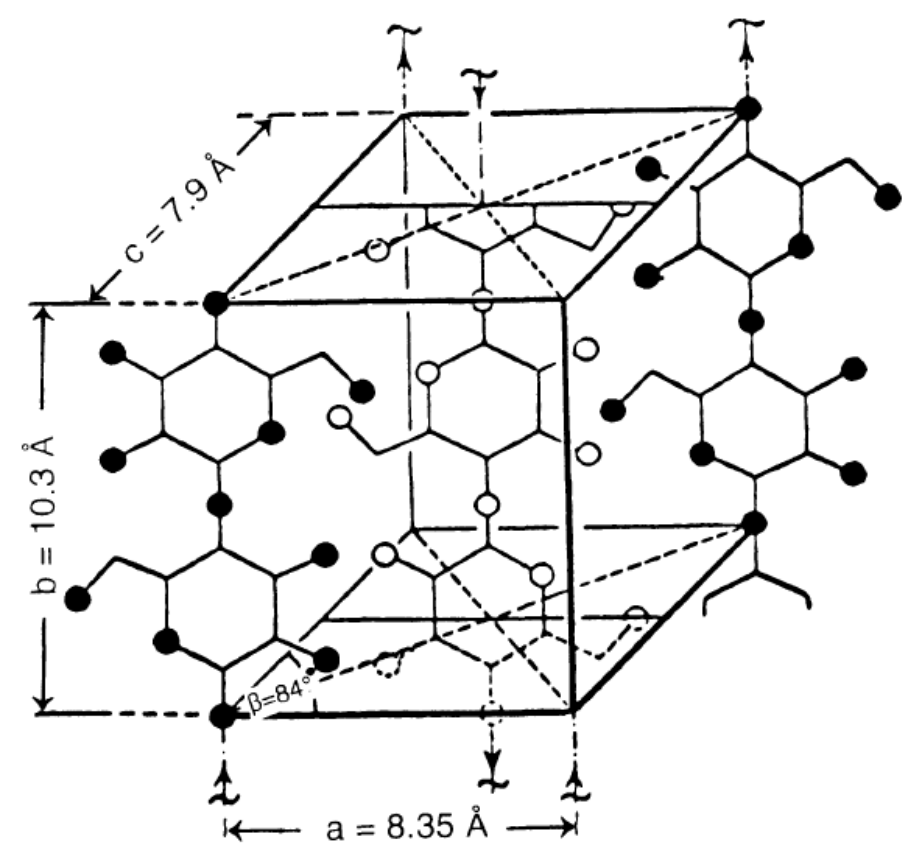

Fonte: (KLEMM et al., 1998)

A celulose além de se apresentar na forma cristalina, também pode aparecer em algumas regiões da planta de forma amorfa, que é uma estrutura de menor rigidez e mais susceptível à hidrólise (KLEMM et. al., 1998).

A lignina é uma macromolécula amorfa, representando 20 a 30\% do total dos materiais lignocelulósicos. A molécula é formada pela polimerização radicalar dos álcoóis p-cumarílico, coniferílico e sinapílico (Figura 3). Essa polimerização não ocorre de forma regular nem repetitiva e por isso há diferença na constituição da lignina nos diferentes materiais lignocelulósicos existentes. Os monômeros geram uma macromolécula onde predominam as ligações do tipo $\beta-\mathrm{O}-4$ e $\alpha-\mathrm{O}-4$ (50-65\%), seguidas por $\beta-5$ (6-15\%), $\beta-1$ (9-15\%), $5-5$ (2-9\%) e $\beta-\beta(2-5 \%)$ (FENGEL \& WEGENER, 1989). Em madeiras de coníferas, a lignina é denominada de lignina guaiacil (lignina $G$ ) e tem composição quase que exclusiva do precursor álcool coniferílico, podendo conter quantidades bem pequenas de álcool p-cumarílico. Em madeiras de folhosas é denominada siringil-guaiacil (SG), onde tanto os derivados do álcool coniferílico quanto sinapílico coexistem em proporções parecidas ou até 3 vezes maior de álcool sinapílico (Figura 4). Em 
monocotiledôneas a lignina é denominada HGS (Hidroxi fenil, Guaiacil, Siringil), pois contém todos os 3 tipos de álcoois como precursores (HENRIKSSON, 2009).

Figura 3- Álcoois precursores da lignina

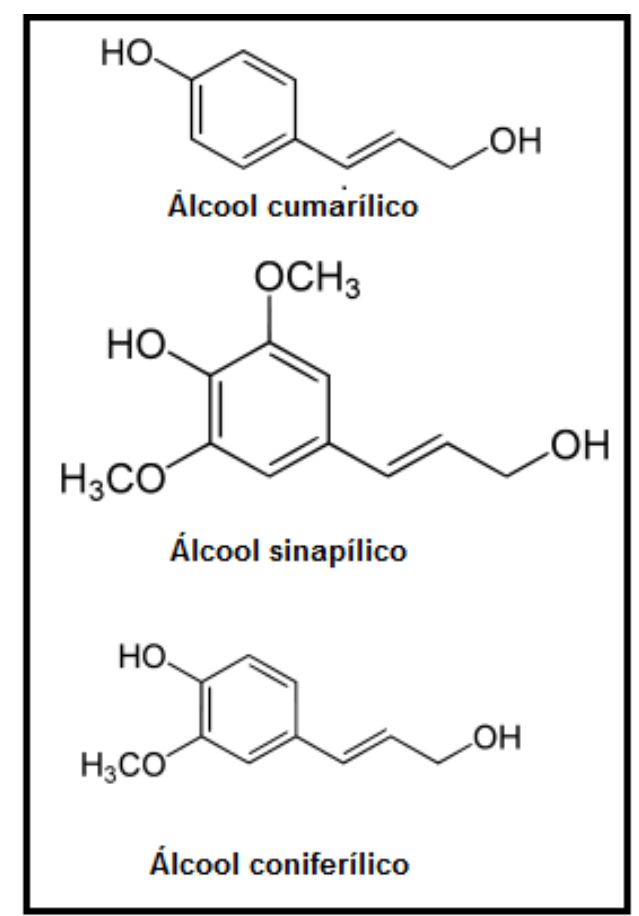

Fonte: (HENRIKSSON, 2009)

Figura 4- Estrutura sugerida de lignina de madeira de folhosas.

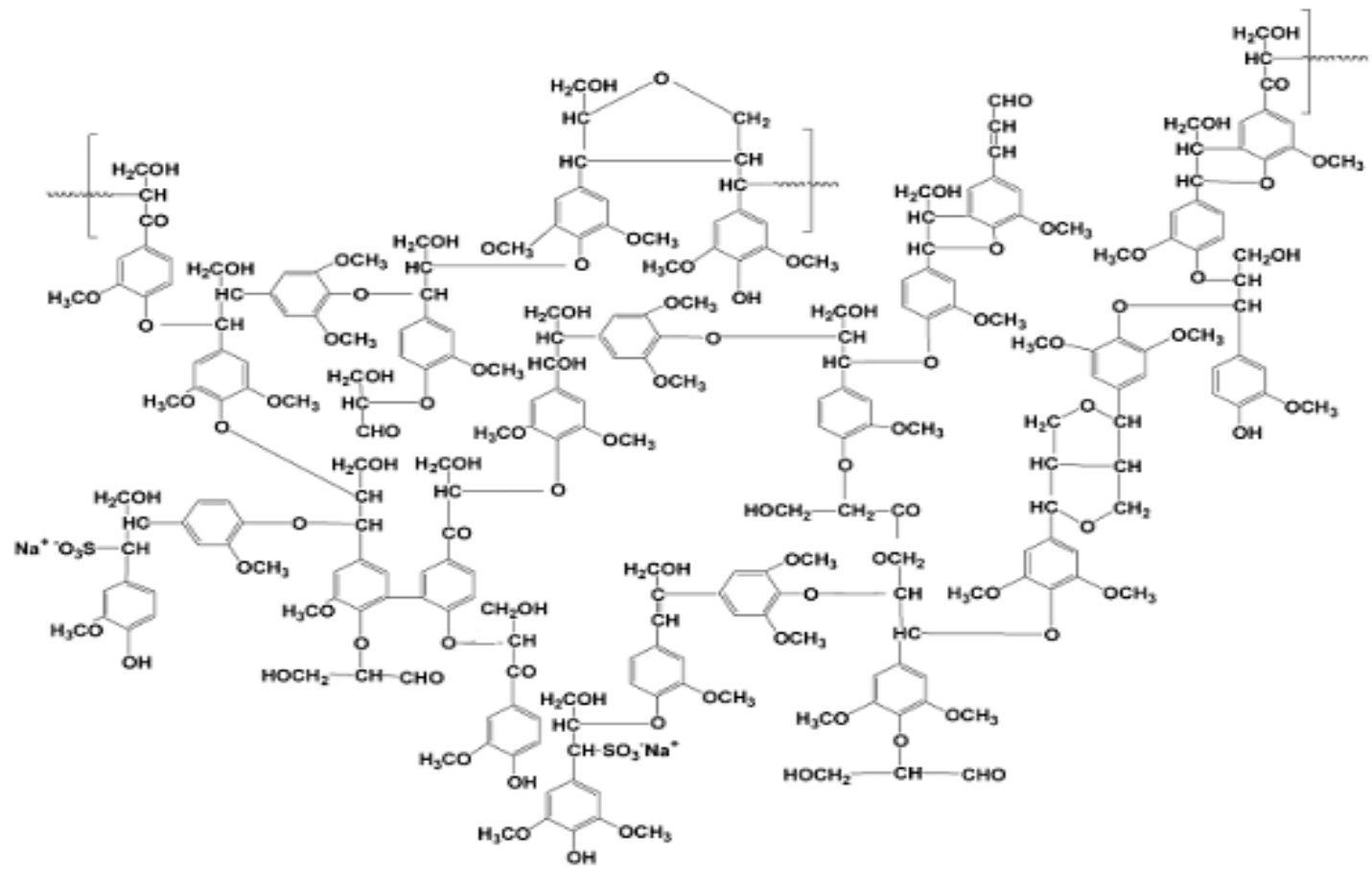

Fonte: (MOHAN; PITTMAN; STEELE, 2006) 
$\mathrm{Na}$ lignina de monocotiledôneas são ainda encontrados ácidos hidroxicinâmicos (ferúlico e p-cumárico) formando ligações éter ou éster. Ainda não está completamente elucidado em quais posições estes ácidos se ligam à lignina, mas há evidências que quando o ácido forma um éster com uma hemicelulose, a posição 4 do anel aromático apresenta o oxigênio formando um éter no carbono a da cadeia lateral das unidades fenil-propano (LAM; KADOYA; IIYAMA, 2001) (Figura 5).

Figura 5- Ligação $\alpha$ - éter entre lignina e hidroxinamatos.

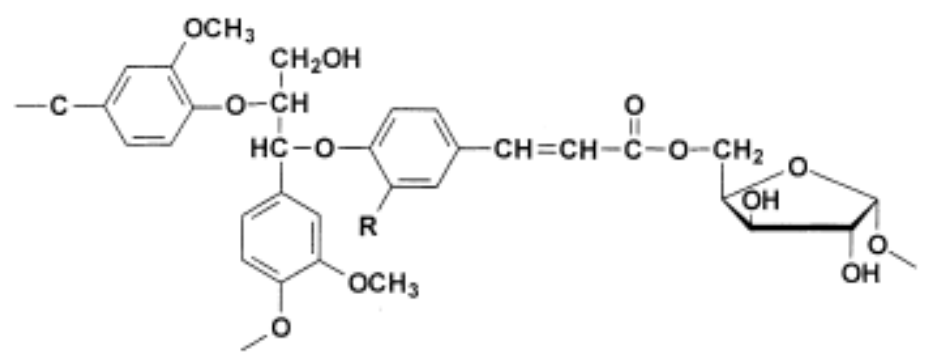

Fonte: (LAM; KADOYA; IIYAMA, 2001)

Os materiais lignocelulósicos contém ainda hemicelulose e uma fração denominada extrativos (2 a 4\% aproximadamente), a qual é composta de resinas e compostos fenólicos (FENGEL; WEGENER, 1989).

A fração hemicelulósica, por ser a principal fração de interesse para o presente trabalho, será abordada separadamente nos tópicos a seguir.

\subsubsection{HEMICELULOSE}

O termo "hemicelulose" é antigo e define um grupo de polissacarídeos pertencentes à parede celular vegetal que não se caracteriza como celulose nem como pectina (SCHELLER; ULVSKOV, 2010). É o segundo polissacarídeo mais abundante na biomassa lignocelulósica, representando cerca de 20-35\% da massa seca (TELEMAN, A., 2009). Os processos de bioconversão da hemicelulose tem ganhado destaque devido à possibilidade de aplicação industrial em etapas de biobranqueamento da polpa celulósica, de aumento da 
digestibilidade de rações animais, na clarificação de sucos e no aumento da consistência de cervejas (SAHA, 2003a). A conversão da hemicelulose em etanol também tem sido o foco de diversas pesquisas, pois trata-se de uma parcela importante da fração polissacarídica da biomassa vegetal (GíRIO et al., 2010).

Diferentemente da celulose, a hemicelulose pode ser um homopolímero ou heteropolímero possuindo em sua cadeia principal monômeros de xilose, glicose ou manose ligados entre si por ligações $\beta$ - $(1 \rightarrow 4)$. Estes polissacarídeos apresentam a mesma configuração equatorial na ligação éter entre os carbonos 1 e 4 e, por isso, os esqueletos apresentam similaridade estrutural (Figura 6) (SCHELLER; ULVSKOV, 2010). Esses esqueletos possuem grupos pendentes que podem ser compostos por arabinose, galactose, ácido-O-metil-glucurônico, ácido ferúlico e cumárico (TELEMAN, A., 2009; SAHA, 2003a). Outros açúcares também podem estar presentes em quantidades pequenas como $\alpha$-L-ramnose e a-L-fucose e os grupos hidroxila dos açúcares podem ser parcialmente substituídos por grupos acetila (GÍRIO et al., 2010).

Figura 6- Hemiceluloses caracterizadas por ligação $\beta$ - $(1 \rightarrow 4)$ com configuração equatorial em $C 1$ e C4.
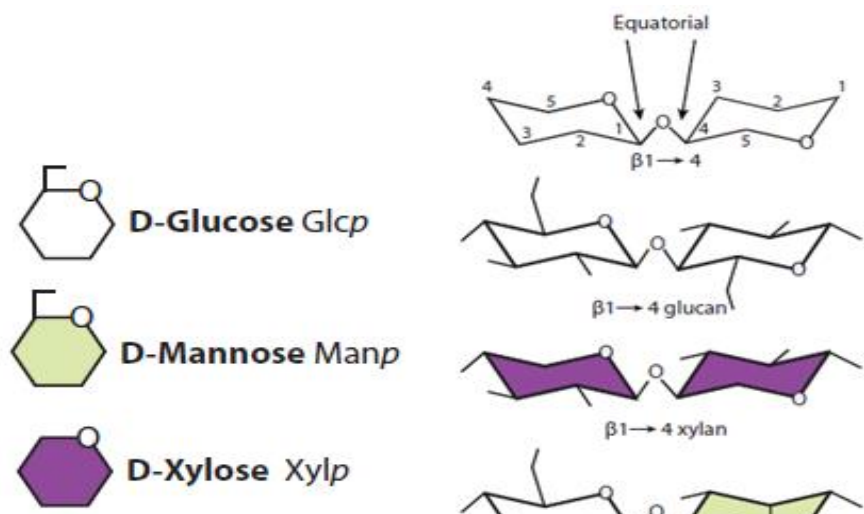

$\beta 1 \rightarrow 4$ glucan

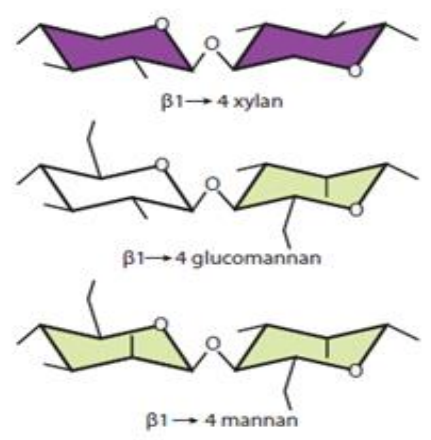

Fonte: (SCHELLER; ULVSKOV, 2010)

Devido à sua heterogeneidade, as hemiceluloses podem ser classificadas em vários tipos que estão apresentados na Tabela 1 (GíRIO et al., 2010). 
Entretanto, nessa revisão serão detalhadas apenas as xilanas que são principalmente encontradas em gramíneas (4-O-metil-glucuronoarabinoxilanas) e que são o foco do trabalho.

Tabela 1- Principais tipos de polissacarídeos presentes nos diferentes tipos de hemicelulose e sua classificação

\begin{tabular}{|c|c|c|c|c|c|}
\hline Tipo de polissacarídeo & $\begin{array}{l}\text { Origem } \\
\text { biológica }\end{array}$ & $\begin{array}{c}\text { Quantidade } \\
\text { (\% massa } \\
\text { seca) }\end{array}$ & Esqueleto & $\begin{array}{c}\text { Unidades } \\
\text { Cadeias laterais }\end{array}$ & Ligação \\
\hline Arabinogalactana & Coníferas & $1-3 ; 35$ & $\beta$-D-Galp & $\begin{array}{c}\beta \text {-D-Galp } \\
\alpha-L-A r a f \\
\beta \text {-L-Arap }\end{array}$ & $\begin{array}{l}\beta-(1 \rightarrow 6) \\
\alpha-(1 \rightarrow 3) \\
\beta-(1 \rightarrow 3)\end{array}$ \\
\hline Xiloglucana & $\begin{array}{l}\text { Folhosas e } \\
\text { gramíneas }\end{array}$ & $2-25$ & $\begin{array}{l}\beta-D-G l c p \\
\beta-D-X y l p\end{array}$ & $\begin{array}{c}\beta \text {-D-Xylp } \\
\beta \text {-D-Galp } \\
\alpha \text {-L-Araf } \\
\alpha \text {-L-Fucp } \\
\text { Acetil }\end{array}$ & $\begin{array}{l}\beta-(1 \rightarrow 4) \\
\alpha-(1 \rightarrow 3) \\
\beta-(1 \rightarrow 2) \\
\alpha-(1 \rightarrow 2) \\
\alpha-(1 \rightarrow 2)\end{array}$ \\
\hline Galactoglucomana & Coníferas & $10-25$ & $\begin{array}{l}\beta \text {-D-Manp } \\
\beta \text {-D-Glcp }\end{array}$ & $\begin{array}{l}\beta \text {-D-Galp } \\
\text { Acetil }\end{array}$ & $\alpha-(1 \rightarrow 6)$ \\
\hline Glucomanana & $\begin{array}{l}\text { Coníferas e } \\
\text { folhosas }\end{array}$ & $2-5$ & $\begin{array}{l}\beta \text {-D-Manp } \\
\beta \text {-D-Glcp }\end{array}$ & & \\
\hline Glucuronoxilana & Folhosas & $15-30$ & $\beta$-D-Xylp & $\begin{array}{l}\text { 4-O-Me- } \alpha \text {-D-Glcp-A } \\
\text { Acetil }\end{array}$ & $\alpha-(1 \rightarrow 2)$ \\
\hline Arabinoglucoronoxilana & $\begin{array}{l}\text { Gramíneas } \\
\text { e cereais e } \\
\text { coníferas }\end{array}$ & $5-10$ & $\beta-D-X y l p$ & $\begin{array}{c}\text { 4-O-Me- } \alpha-D-G l c p-A \beta-L- \\
\text { Araf }\end{array}$ & $\begin{array}{l}\alpha-(1 \rightarrow 2) \\
\alpha-(1 \rightarrow 3)\end{array}$ \\
\hline Arabinoxilana & Cereais & $0,15-30$ & $\beta-D-X y \mid p$ & $\alpha$-L-ArafFeruloil & $\begin{array}{l}\alpha-(1 \rightarrow 2) \\
\alpha-(1 \rightarrow 3)\end{array}$ \\
\hline Glucuronoarabinoxilana & $\begin{array}{l}\text { Gramíneas } \\
\text { e cereais }\end{array}$ & $15-30$ & $\beta-D-X y l p$ & $\begin{array}{c}\alpha-L-A r a f \\
\text { 4-O-Me- } \alpha-D-G l c p-A \\
\text { Acetil }\end{array}$ & $\begin{array}{l}\alpha-(1 \rightarrow 2) \\
\alpha-(1 \rightarrow 3)\end{array}$ \\
\hline Homoxilanas & Algas & & $\beta-D-X y \mid p^{*}$ & & \\
\hline
\end{tabular}

*Ligações $\beta-(1 \rightarrow 3)$ podem estar presentes.

Fonte:(GíRIO et al., 2010)

As xilanas são constituídas por um esqueleto de anidroxilose que é ligado entre si por ligações $\beta-(1 \rightarrow 4)$ que podem apresentar resíduos de arabinose e ácido a-1,2-4-O-metilglucurônico, além de substituintes com função éster como grupos O-acetila e ácidos ferúlico e p-cumárico (SAHA, 2003b) (Figura 7). 
Figura 7- Esquema de xilana de caule de milho.

A: arabinose; X: xilose; G: galactose; FeA: ácido ferúlico; GlcA: ácido glucurônico

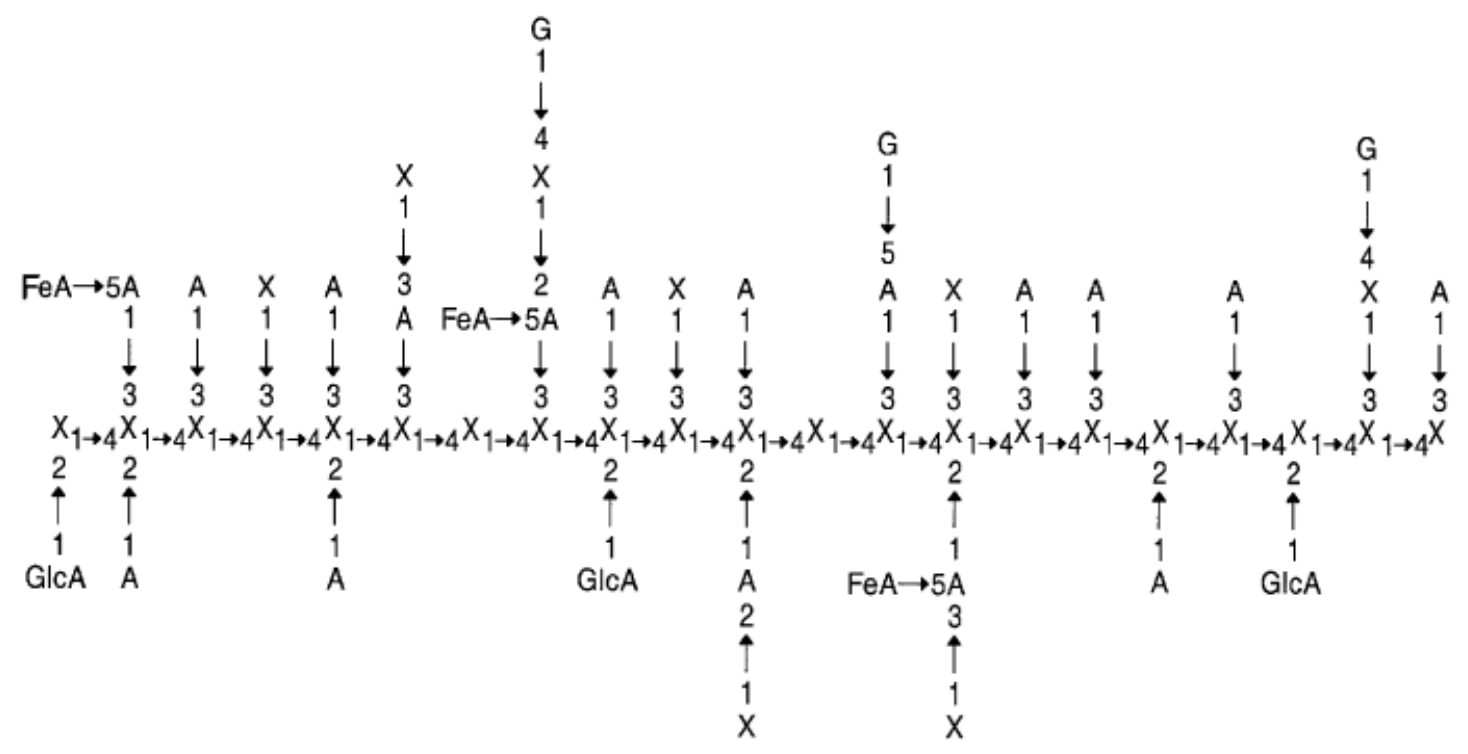

Fonte: (SAHA, 2003b).

Em gramíneas, as xilanas constituem a maior porção polissacarídica não celulósica da parede celular secundária (cerca de $20 \%$ da parede). Essas xilanas geralmente contém vários resíduos de arabinose e ácido 4-O-metil glucurônico ligados à cadeia principal Em gramíneas, os grupos $\mathrm{O}$-acetila correspondem a 1 a $3 \%$ da biomassa seca. Estes grupos se ligam aos resíduos de xilose na posição O-3 ou O-2 (em menor quantidade) (SCHELLER; ULVSKOV, 2010; SINGH; MISHRA, 1995; BIELY, et. al., 1985). Nas gramíneas há ainda a presença de ácidos fenólicos como substituintes das xilanas. Por exemplo, em xilana de palha de cevada está descrito que 1 de cada 31 resíduos de arabinose está esterificado com ácido p-cumárico e 1 de cada 15 com ácido ferúlico (SINGH; MISHRA, 1995).

Os ésteres e éteres do ácido p-cumárico são abundantes nas gramíneas e estão principalmente associados à lignina, porém não está claro se eles podem se ligar diretamente à xilana e se estão envolvidos em ligações cruzadas na parede celular (SCHELLER; ULVSKOV, 2010). Por outro lado, está bem descrito que o ácido ferúlico é ligado à posição 0-5 de resíduos arabinofuranosil das xilanas Dímeros de ferulato são facilmente detectáveis na parede de gramíneas e representam ligações intra e intermoleculares entre glucuronoarabinoxilanas. Ferulato também pode estar ligado de forma cruzada com lignina (através de 
ligações éter) e pode-se assumir que as glucuronoarabinoxilanas e lignina se tornam covalentemente ligadas através dessas ligações (SINGH; MISHRA, 1995). Através dessas ligações que os ácidos ferúlico e cumárico realizam, a parede celular se torna mais recalcitrante à ação de enzimas hidrolíticas (FAULDS; SANCHO; BARTOLOMÉ, 2002).

Devido à importância dos ácidos ferúlico e cumárico e para melhor compreendê-los, um tópico especial sobre ácidos hidroxicinâmicos foi descrito isoladamente.

\subsubsection{1 ÁCIDOS HIDROXICINÂMICOS}

Compostos fenólicos são característicos de plantas e são muito importantes para a vida da mesma, pois estão envolvidos no suporte e proteção dos tecidos, mecanismos de defesa e sinalização. Compostos fenólicos simples como os ácidos hidroxicinâmicos e flavonóides também são encontrados em frutas e bebidas e contém uma grande variedade de atividades antioxidantes in vitro. Está demonstrado que estes compostos exercem efeitos de proteção contra doenças graves como o câncer e doenças cardiovasculares (BOUDET, 2007).

Os ácidos fenólicos, principalmente os ácido ferúlico e p-cumárico, existem particularmente em gramíneas e são conhecidos pela capacidade de realizarem ligações cruzadas entre os polímeros de lignina e hemicelulose (YANG et al., 2009; PANAGIOTOU; OLAVARRIA; OLSSON, 2007). LAM; STONE (1994) revisaram a literatura e descreveram três tipos de ligações cruzadas propostas entre lignina e polissacarídeos, nas quais duas são covalentes (Figura 8). A primeira é uma ligação direta do tipo éster entre ácidos urônicos presentes na hemicelulose e grupos hidroxila presentes na superfície da lignina formando ésteres $\alpha$ ou y nas cadeias laterais do monolignol (Figura 8a). A ligação do tipo éster a pode ser formada pela reação de intermediários de metileno quinonas das unidades precursoras de lignina com carboxilas de ácido urônico. O segundo tipo de ligação proposta é uma ligação éter direta entre os polissacarídeos e a lignina (Figura 8b). Essas ligações também podem ser formadas pela reação de intermediário metileno quinona na superfície da lignina e resíduos de monossacarídeos na superfície de polissacarídeos. Ésteres hidroxicinamílicos de polissacarídeos também são encontrados nas paredes de células lignificadas de 
gramíneas (Figura 8c). Além disso, ácidos hidroxicinâmicos podem estar diretamente esterificados (Figura 8d) ou eterificados (Figura 8e) à lignina. Scalbert et al. (1986) propôs que o ácido ferúlico poderia formar pontes covalentes ésteréter entre polissacarídeos e lignina (Figura 8f). Evidências desse tipo de ligação em palha de trigo foram dadas por Scalbert et al. (1985) e liyama et al. (1990). Foi sugerido também que todo o ácido ferúlico presente em trigo é esterificado presumivelmente aos polissacarídeos, embora ligações entre lignina-lignina não são descartadas (LAM et al., 1992a). O ácido dihidrodiferúlico faz ligações di-éster entre polissacarídeos (Figura 8g) e pode estar eterificado à lignina (Figura 8h) ( LAM et al., 1992b).

Figura 8- Diagrama esquemático mostrando as possíveis ligações cruzadas entre lignina e polissacarídeos. a) ligação éster direta; b) ligação éter direta; c) ácido hidroxicinâmico esterificado a polissacarídeos; d) ácido hidroxicinâmico esterificado à lignina; e) ácido hidroxicinâmico eterificado à lignina; f) ponte de ácido ferúlico éster-éter; g) ponte di-éster de ácido dihidro diferúlico; h) ponte di-éster-éter de ácido dihidro diferúlico

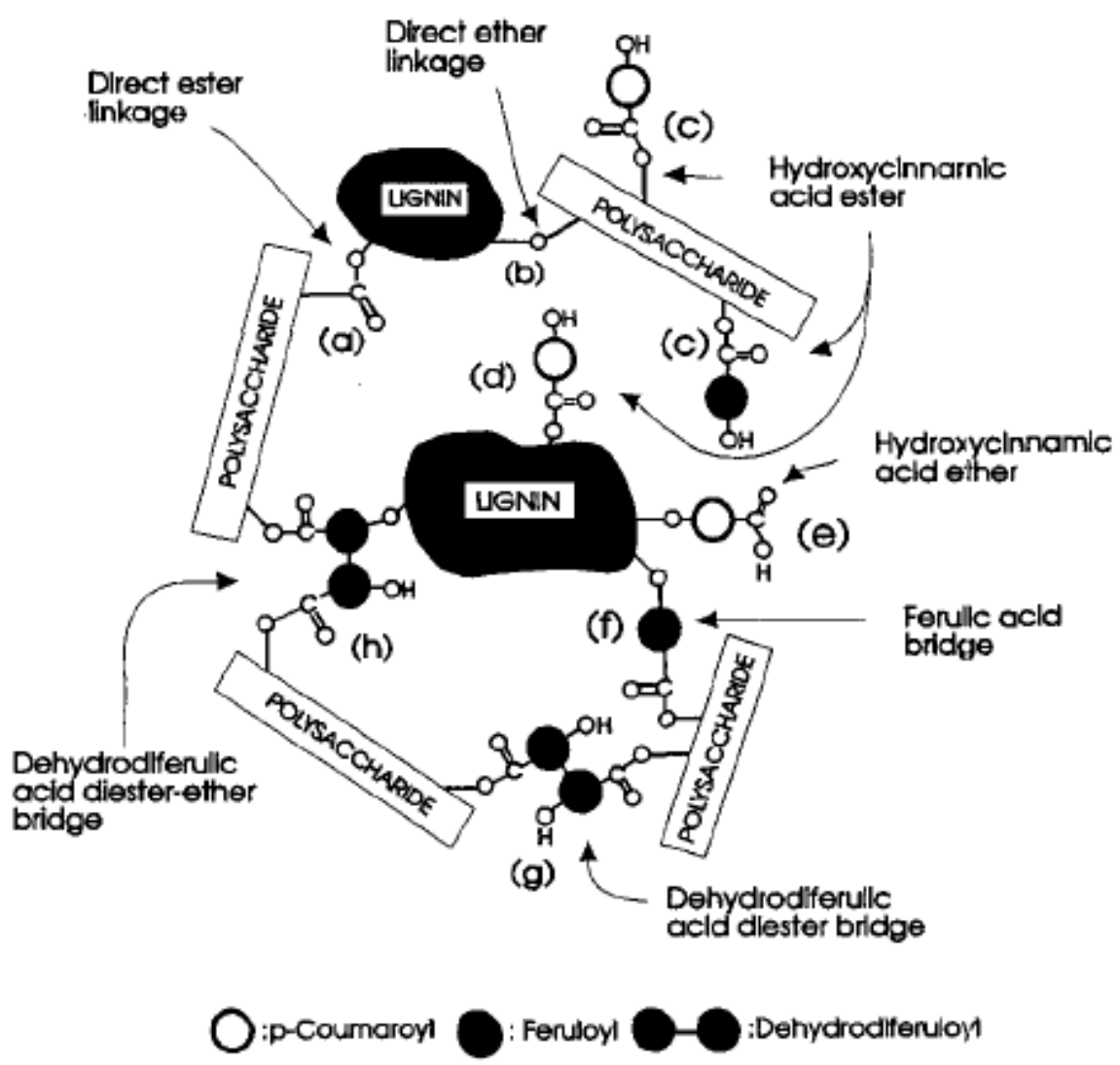

Fonte: (LAM; STONE, 1994). 
Ralph et al. (1992) e Ralph e Helm (1993) sugeriram que o ferulato é ligado através de ligação éter na posição $\beta$ da cadeia lateral da lignina através de uma reação de acoplamento de radicais entre ferulato e radicais de monolignol. Entretanto, em um trabalho mais recente Lam, Kadoya, \& liyama (2001) obtiveram resultados que indicam que a maioria dos ácidos hidroxicinâmicos (aproximadamente $80 \%$ ) se ligam através de ligação éter na posição benzílica da lignina e não na posição $\beta$ como outros autores já haviam sugerido (Figura 9).

Figura 9- Possíveis ligações entre lignina e ácidos hidroxicinâmicos.

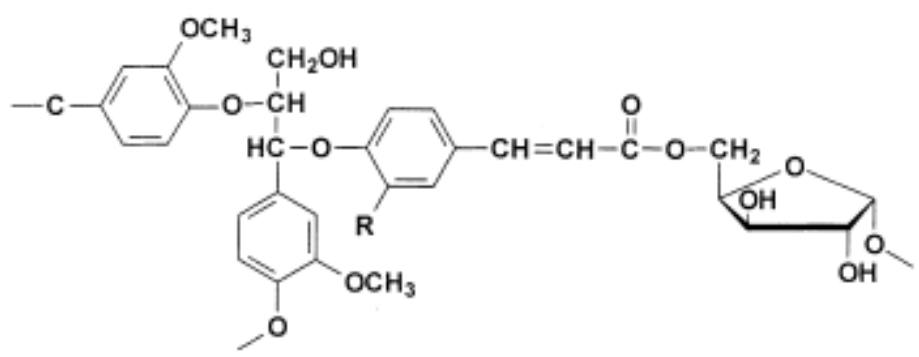

a) Ligação a éter entre a lignina e hidroxinamatos

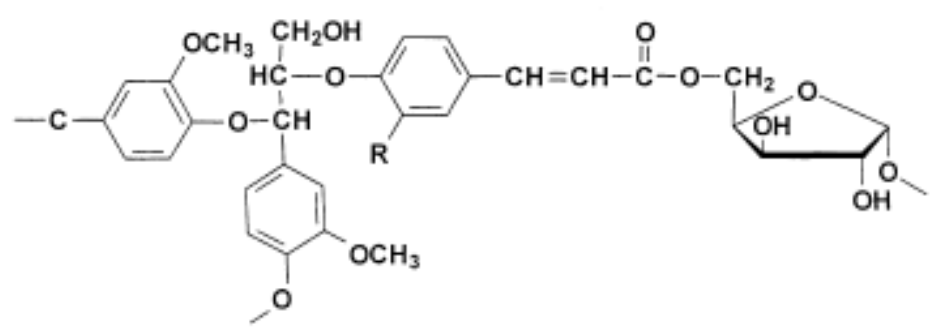

b) Ligação $\beta$ éter entre lignina e hidroxinamatos $\mathrm{R}=\mathrm{H}$ : p-cumarato, $\mathrm{R}=\mathrm{OCH}_{3}$ : ferulato Fonte: (LAM, KADOYA, \& IIYAMA, 2001)

Shimada et al. (1971) propôs que a maioria das moléculas de ácido p-cumárico encontram-se esterificadas ao polímero de lignina no carbono gama visualizado na figura 10 (SABERIKHAH, MOHAMMADI-ROVSHANDEH \& MAMAGHANI 2013; LI et al., 2012). 
Figura 10- Ligação éster entre ácido p-cumárico e lignina.

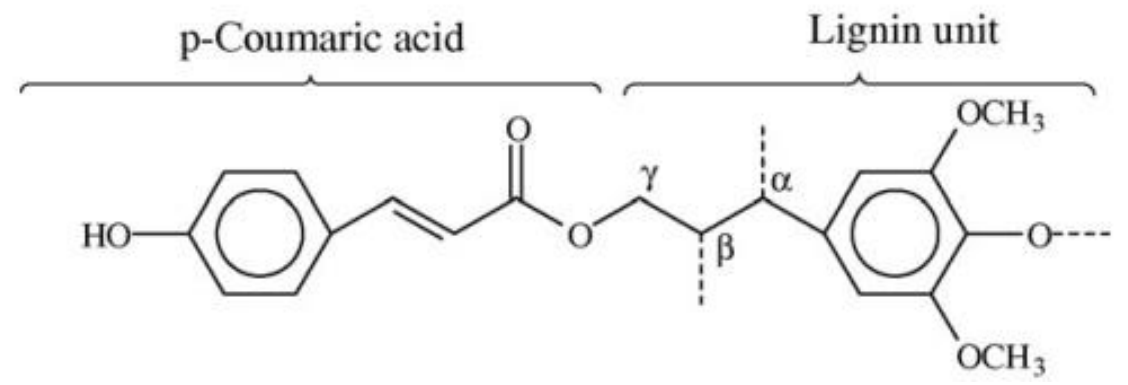

Fonte: (SABERIKHAH, MOHAMMADI-ROVSHANDEH \& M. MAMAGHANI, 2012)

\subsubsection{1 ÁCIDO FERÚLICO E P-CUMÁRICO}

O ácido ferúlico (Figura 10) é encontrado facilmente na natureza. Exibe poder antioxidante, serve como conservante para alimentos, atua como antiinflamatório, fotoprotetor (age como uma barreira na membrana celular impedindo a atividade de radicais livres e minimizando os efeitos dos dímeros de timina, que são agentes carcinogênicos resultantes da exposição da pele à radiação UV) e como flavorizante. Também é visto como uma escala de commodities, podendo ser utilizado para a conversão biocatalítica a outros produtos químicos aromáticos úteis (FAULDS et al., 2002; ROSAZZA et al., 1995).

Figura 11- Estrutura do ácido 2-propenóico,3-(4-hidroxi-3-metoxifenil) (ácido ferúlico).<smiles>COc1cc(/C=C/C(=O)O)ccc1O</smiles>

Em plantas é encontrado, tanto na forma monomérica quanto dimérica, principalmente esterificado à hidroxila do $\mathrm{C}-5$ de resíduos arabinosil em arabinoxilanas (SINGH; MISHRA, 1995). Encontram-se também ligado à lignina através de ligação éter. Há evidências que esses grupos fenólicos esterificados sofrem dimerização in vivo pelo acoplamento oxidativo, formando o ácido dehidrodiferúlico ou por fotodimerização, formando uma série de ácidos truxílicos substituídos e ligações cruzadas de ácido truxínico (MOREIRA et. al., 2011) Como dito anteriormente no item 1.1.1.1, ésteres de ferulato e diferulato 
copolimerizam com monolignóis fazendo ligações cruzadas entre xilanas e ligninas, mas além disso, também funcionam como sítio de nucleação para a lignificação (FAULDS et al., 2002). É difícil elucidar o caminho do ácido ferúlico e diferúlico, visto que a sua deposição, dehidrodimerização e copolimerização com a lignina provavelmente ocorrem concomitantemente durante a formação da parede celular em gramíneas. Entretanto, cada passo desse processo pode ser isolado e elucidado usando suspensão de células como um sistema modelo de como a parede celular se desenvolve em gramíneas (GRABBER; RALPH; HATFIELD, 2000).

$\mathrm{O}$ ácido p-cumárico (Figura 11) tem ação antioxidante e é preventivo de certas doenças como câncer do cólon e doenças cardiovasculares e já foi reportado que in vivo sua absorção ocorre eficientemente no intestino (LIU et. al., 2006). É derivado da hidroxilação de ácido cinâmico que também pode se transformar em ácido cafeico, ferúlico e sinapínico. Todos os quatro ácidos citados são intermediários importantes no metabolismo e síntese da lignina. Os monômeros da lignina podem ser formados de duas maneiras principais, a primeira rota vai do ácido $p$-cumárico a cumaroil-CoA, aldeído coniferílico, álcool coniferílico e álcool sinapílico. A segunda vai de fenilalanima a ácido cinâmico, ácido p-cumárico, cumaroil-CoA, aldeído cumárico e aldeído coniferílico, que depois formam o álcool coniferílico e sinapínico através de rotas diferentes (CAl et al., 2010). Embora a função do ácido p-cumárico na estrutura e desenvolvimento da parede celular ainda não é bem compreendida, pequenas quantidades de ácido p-cumárico se encontram esterificados à arabinoxilanas no desenvolvimento inicial da parede celular primária, entretanto no desenvolvimento tardio da parede ele se encontra extensivamente esterificado à lignina (RALPH et al., 1994; POLIZELI, M.L.T.M. et al., 2011)

Figura 12- Estrutura molecular do ácido p-cumárico

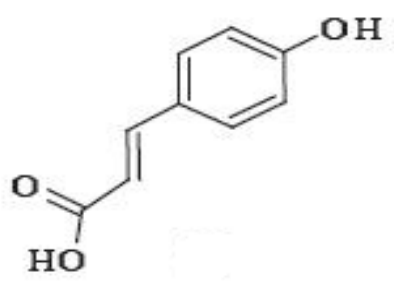




\subsection{HIDRÓLISE ENZIMÁTICA DOS MATERIAIS LIGNOCELULÓSICOS}

A degradação enzimática do material lignocelulósico geralmente ocorre com baixa eficiência, pois a maioria dos polissacarídeos é insolúvel ou está fortemente associado à matriz insolúvel. Na natureza, a degradação de um material lignocelulósico depende da ação de diversos organismos como fungos e bactérias. Os fungos são os mais eficientes na degradação de materiais lignocelulósicos e produzem várias enzimas que são secretadas e agem sobre o material levando a uma despolimerização inicial resultando na formação de compostos menores que são então transportados através da membrana celular e utilizados no metabolismo intracelular (ARANTES; MILAGRES, 2009; FERRAZ, 2004). Esses fungos são classificados em fungos de degradação branca, os quais são capazes de degradar a lignina e polissacarídeos e fungos de degradação parda, que degradam majoritariamente os polissacarídeos.

\subsubsection{ENZIMAS ENVOLVIDAS NA DEGRADAÇÃO DA PAREDE CELULAR VEGETAL}

Estudos sobre as enzimas envolvidas na degradação da parede celular vegetal tem sido realizados desde 1950, tendo em vista a obtenção dos açúcares que são utilizados na indústria para diversas finalidades. Enzimas hidrolíticas como celulases, xilanases e manases estão envolvidas na degradação da fração polissacarídica da parede celular, enquanto que as enzimas oxidativas como lacase, lignina peroxidase e manganês peroxidase juntamente com mediadores de baixa massa molar estão envolvidos na degradação da lignina (MOREIRA et. al., 2011)

Algumas enzimas hidrolíticas podem ter ação endo ou exo e geralmente agem sinergicamente para alcançar a conversão total da parede celular. Podem existir como um complexo multienzimático, como no caso do celulossomo de Clostridium thermocelum ou como enzimas individuais interagindo umas com as outras formando um "sistema", como no caso das enzimas que degradam xilanas ou as enzimas que degradam celulose (FAULDS; WILLIAMSON, 1994, LEVASSEAUR et al., 2013). 


\subsubsection{CELULASES}

Muitos micro-organismos são capazes de degradar a celulose, especialmente os pertencentes à eubacteria e fungi. Na degradação da celulose existem três tipos de hidrolases que atuam em conjunto: as endo-1,4- $\beta$ glucanases, exo-1,4- $\beta$-glucanases, também chamadas de celobidrolases, e as $\beta$ glicosidases. As endo-1,4- $\beta$-glucanases atuam no interior da cadeia gerando cadeias de terminação redutora e não redutora possibilitando a atuação das exo1,4- $\beta$-glucanases que levam à formação de celobiose que é convertida em glicose pelas $\beta$-glicosidases (HORN et. al.,2012; PÉREZ et. al., 2002). Ambas as endo e exo-1,4- $\beta$-glucanases são capazes de degradar a celulose amorfa, mas em geral somente as exo são capazes de degradar a celulose cristalina. Os organismos celulolíticos podem interagir com os não celulolíticos levando à completa degradação da celulose, formando gás carbônico e água em meio aeróbico ou à formação de dióxido de carbono, metano e água em meio anaeróbico (PÉREZ et. al., 2002).

Como descrito por Horn et. al. (2012) em seu artigo de revisão, além das três enzimas já citadas, existem outros contribuintes na degradação da celulose que seriam componentes não hidrolíticos capazes de diminuir o empacotamento da celulose facilitando o acesso das enzimas hidrolíticas. Esses componentes seriam as polissacarídeo monoxigenases (PMOs), hoje denominadas AA9, antigamente chamadas de glicosil hidrolases da família 61 (GH61) (Levasseaur et al., 2013). Essas AA9 são capazes de catalisar a quebra oxidativa da celulose em uma reação dependente de cobre em presença de um doador de elétrons, oxidando o carbono $\mathrm{C} 1, \mathrm{C} 4$ ou até mesmo o $\mathrm{C} 6$. Podem receber elétrons da celobiose desidrogenase, uma enzima presente em fungos que é secretada juntamente com AA9 para degradar celulose ou podem receber elétrons da própria lignina quando o substrato é um material lignocelulósico (Figura12).

A análise tridimensional da estrutura das polissacarídeo monooxigenases revelaram estrutura com dobramentos beta contendo um sítio ativo com um metal coordenado por uma histidina N-terminal. (HEMSWORTH et. al., 2013). Análises transcripcionais dos genes das MPOs mostraram que eles são induzidos por celulose ou xilana. Além disso, estão presentes em genes multicópias com diversas isoformas em vários genomas de fungo, incluindo patógenos, 
decompositores de lixo, de degradação branca e parda e micorriza (ZIFCAKOVA; BALDRIAN, 2012). Mutações no sítio de ligação ao cobre ou o uso de quelantes de metais como EDTA mostraram a importância do cobre para o funcionamento da enzima, uma vez que a enzima, na ausência de cobre, mostrou-se inativa (ZIFCAKOVA; BALDRIAN, 2012).

Figura 13- Reações catalizadas pelas polissacarídeo monooxigenases (PMOs) e sua interação com celobiose

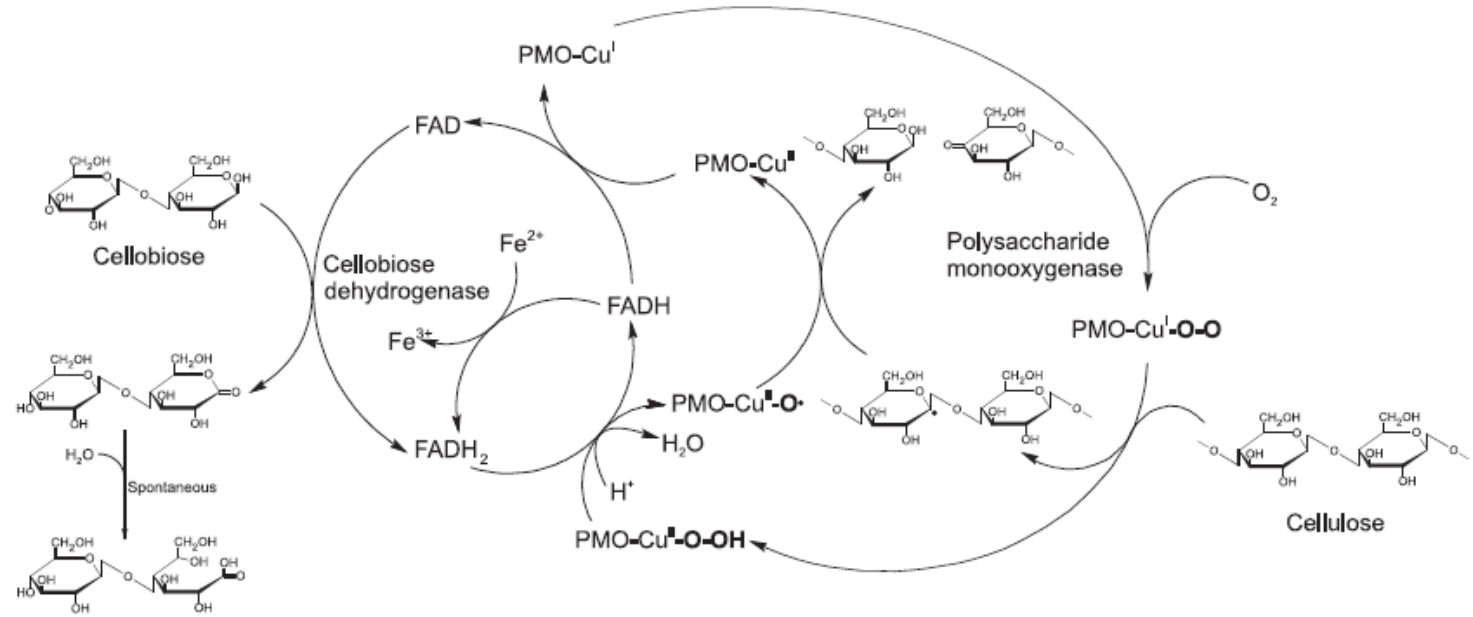

Fonte: (ZIFCAKOVA; BALDRIAN) 2012.

\subsubsection{XILANASES}

No caso específico da hidrólise de xilanas, as xilanases são enzimas muito importantes. Estas enzimas compreendem um grupo de enzimas responsáveis pela quebra das ligações glicosídicas do esqueleto das xilanas e são produzidas por fungos, bactérias, leveduras, algas marinhas, protozoários, caramujos, crustáceos, insetos e sementes (GÍRIO et al., 2010). Os fungos filamentosos se destacam, pois produzem altas quantidades dessas enzimas. Aspergillus niger, Humicola insolens, Termomonospora fusca, Trichoderma reesei, $T$. longibrachiatum, T. koningii são usados como fontes de xilanases comerciais que podem ser utilizadas na indústria para produção de papel, ração animal, pães, indústrias de suco e vinho 
As principais xilanases são a endo-1,4- $\beta$-xilanase e a $\beta$-xilosidase. Elas não atuam de forma aleatória, visto que as ligações a serem hidrolisadas são selecionadas de acordo com a natureza do substrato como, por exemplo, o comprimento da cadeia, grau de ramificação e a presença de substituintes. Como algumas xilanases não clivam as ligações da cadeia principal nos pontos próximos àqueles em que há substituintes, as cadeias laterais devem ser removidas previamente, por isso a atividade de enzimas acessórias como Larabinofuranosidases, glucuronidases, acetilxilana esterases e feruloil esterases é essencial (Tabela 2). Por outro lado, algumas enzimas que atuam nas cadeias laterais só conseguem atuar em xilo-oligossacarídeos, que devem ser produzidos previamente por endoxilanases (GÍRIO et al., 2010). Por isso, para que a degradação da xilana seja efetiva deve ocorrer uma interação sinérgica entre as enzimas de despolimerização e de quebra da cadeia lateral (Figura 13). As endoxilanases atacam a cadeia principal e $\beta$-xilosidases clivam pequenos xiloologossacarídeos e xilobiose liberando resíduos $\beta$-D-xilopiranosil da extremidade não redutora. As $\beta$-xilosidases preferem xilobiose como substrato e sua afinidade por xilo-oligossacarídeos é inversamente proporcional ao seu grau de polimerização(TEERI \& HENRIKSSON, 2009). Entre as enzimas acessórias, as $\alpha-$ D-glucuronidases hidrolisam as ligações $\alpha-1,2$ entre os resíduos de ácido glucurônico, as $\alpha$-L-arabinosidases hidrolisam grupos arabinosil e as esterases clivam as ligações éster entre xilana e ácido acético ou entre xilana e ácidos fenólicos (SAHA, 2003b; TEERI \& HENRIKSSON, 2009; GÍRIO et al., 2010).

Tabela 2- Enzimas envolvidas na hidrólise de heteroarabinoxilanas complexas.

\begin{tabular}{ll}
\hline Enzima & Modo de ação \\
\hline Endo-xilanase & Hidrolisa ligações $\beta$-1,4 no interior da cadeia de xilana \\
B-xilosidase & $\begin{array}{l}\text { Libera xilose de xilobiose e xilo-oligossacarídeos de cadeia } \\
\text { pequena }\end{array}$ \\
a-arabinofuranosidase & $\begin{array}{l}\text { Hidrolisa terminais não redutores de a-arabinofuranose de } \\
\text { arabinoxilanas }\end{array}$ \\
a-glucuronidase & Libera ácido glucurônico de glucoronoxilanas \\
Acetil xilana esterase & Hidrolisa ligações acetil éster em acetil xilanas \\
Esterase de ácido ferúlico & Hidrolisa ligações feruloil éster em xilanas \\
Esterase de ácido p-cumárico & Hidrolisa ligações p-cumaril éster em xilanas \\
\hline
\end{tabular}

Fonte: (SAHA, 2003b) 
Figura 14- Especificidade do substrato em algumas hemicelulases.

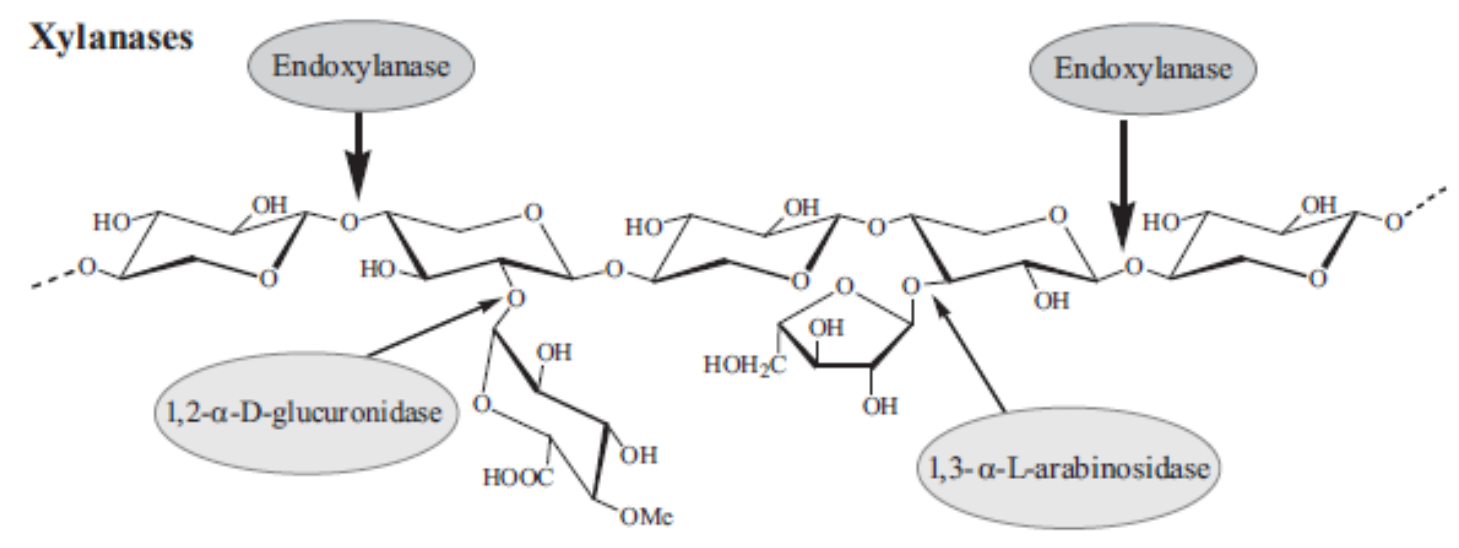

Fonte: (TEERI; HENRIKSSON, 2009).

Vários estudos indicam que as xilanases são enzimas induzíveis principalmente quando a fonte de carbono do meio é variada. Em presença de xilana, xilose, xilobiose ou resíduos $\beta$-D-xilopiranosil, sua secreção foi induzida e em presença de glicose ocorreu repressão catabólica. Entretanto, a produção constitutiva de xilanases também foi reportada (GÍRIO et al., 2010).

A expressão de xilanases em plantas tem sido proposta como uma forma de aumentar a digestibilidade da parede celular vegetal, uma vez que as xilanas atuam como barreiras para a ação de celulases. Várias plantas transgênicas que expressam xilanases já foram produzidas e foi relatado que essas enzimas podem se acumular nos espaços intracelulares de tabaco e também podem ser direcionadas para o cloroplasto ou peroxissomos. Quando uma xilanase foi superexpressada em álamo, a quantidade de xilana na parede celular decresceu para menos da metade (HAYASHI; KAIDA, 2011)

\subsubsection{ESTERASES}

Esterases são enzimas hidrolíticas que clivam ésteres em álcool e ácido na presença de água. Entretanto essa reação é reversível e a formação do éster pode ser favorecida, dependendo das condições do meio reacional (Figura 14). Muitas vezes as esterases são confundidas com as lipases, entretanto elas diferem entre si principalmente pela especificidade pelo substrato, pois as 
esterases clivam ésteres de cadeia acil pequena enquanto que lipases tem especificidade para triacilgliceróis de cadeia longa (PANDA; GOWRISHANKAR, 2005; CHAHINIAN; SARDA, 2009).

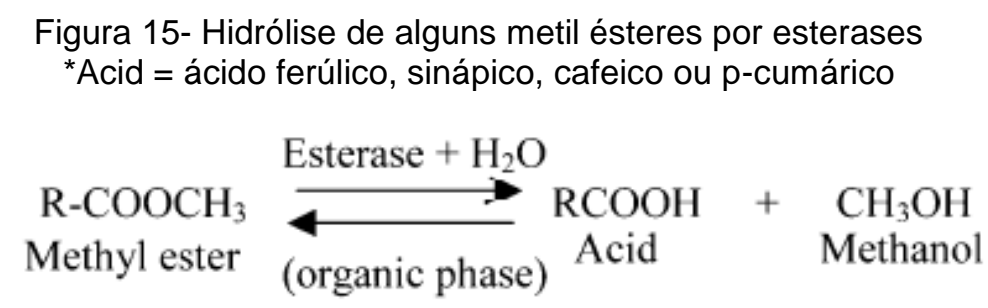

Existem diversos tipos de esterases e elas apresentam diversas aplicações, pois são capazes de transformar produtos de baixo valor agregado em produtos de valor elevado. São empregadas na agricultura, na indústria de alimentos (produção de vinho, sucos de frutas), na produção de cerveja e álcool e na indústria farmacêutica (PANDA; GOWRISHANKAR, 2005).

\subsection{FERULOIL ESTERASES}

As feruloil esterases (FAEs) apresentam denominações sinônimas, tais como esterases de ácido ferúlico, cinamil esterases, cinamil éster hidrolases ou clorogenato esterases, e são enzimas capazes de clivar as ligações éster formadas ente os ácidos hidroxicinâmicos e a hemicelulose. Algumas FAEs já foram descritas a partir de vários micro-organismos como bactérias e fungos, tais como, Pseudomonas fluorescens, Penicillium funiculosum, Talaromyces stipitatus e Aspergillus niger (BENOIT et al., 2006). De uma forma geral, tem sido observado que as enzimas puras geralmente apresentavam baixa atividade quando adicionadas diretamente sobre o substrato cru e que na presença de outras hidrolases (xilanases, L-arabinofuranosidades, metilglucuronidases) há um aumento na quantidade de ácido ferúlico liberada para o meio racional (PANAGIOTOU et al., 2007; BENOIT et al., 2006). Em alguns casos como em farelo de trigo e polpa de beterraba doce foi reportado que quase todo 0 ácido ferúlico do material foi liberado quando uma mistura de feruloil esterase com outras glicosil hidrolases da parede celular foi utilizada (FAULDS et al., 2002). A partir disso, tem sido postulado que o comprimento da cadeia oligossacarídica à 
qual o ácido ferúlico se encontra ligado tem papel fundamental na atividade das FAEs e que as enzimas atuam de forma sinérgica com as hidrolases da parede celular (PANAGIOTOU et al., 2007; RALET, et al. ; FAULDS et al., 2002).

Recentemente, essas esterases foram sequenciadas e a partir de uma comparação genética foi possível classificá-las nos tipos $A, B, C$ e $D$ e estabelecer uma relação evolucionária com acetilxilana esterases e algumas lipases. A classificação estipulada levou em consideração a especificidade das FAEs em relação aos substratos como metil ésteres sintéticos de ácidos hidroxicinâmicos (ácidos ferúlico, diferúlico, p-cumárico, sinápico e caféico), exigências de substrato para o crescimento dos micro-organismos e a identidade da sequência de aminoácidos (FAZARY; JU, 2007). A nomenclatura se faz pelo uso das letras do micro-organismo que produz a enzima seguida por "Fae" e tipo de atividade. Por exemplo, uma esterase do tipo A produzida por Aspergillus niger deve ser denominada de AnFaeA (FAULDS, 2010). A Tabela 3 apresenta algumas características dos diferentes tipos de FAE.

Tabela 3- Classificação das feruloil esterases.

\begin{tabular}{|c|c|c|c|c|}
\hline TIPO DE FAE & TIPO A & TIPO B & TIPO C & TIPO D \\
\hline Micro-organismo & Aspergillus niger & Penicillium funiculosum & $\begin{array}{l}\text { Talaromyces } \\
\text { stipitatus }\end{array}$ & $\begin{array}{l}\text { Pseudomonas } \\
\text { fluorescens }\end{array}$ \\
\hline $\begin{array}{l}\text { Meio de indução } \\
\text { preferencial }\end{array}$ & WB, OSX & SBP & SBP-WB & WB \\
\hline $\begin{array}{l}\text { Hidrólise de metil } \\
\text { ésteres }\end{array}$ & MFA,MSA,MpCA & MFA & $\begin{array}{l}\text { MFA,MSA,MpCA,M } \\
\text { CA }\end{array}$ & MFA,MSA,MpCA,MCA \\
\hline $\begin{array}{l}\text { Liberação de } \\
\text { diferulatos livres } \\
\text { da parede celular }\end{array}$ & $\begin{array}{l}\text { Apenas ácido 5- } \\
\text {,5'-diferúlico }\end{array}$ & Não libera & Não libera & $\begin{array}{l}\text { Apenas ácido 5,5' } \\
\text { diferúlico }\end{array}$ \\
\hline $\begin{array}{l}\text { Similaridade de } \\
\text { sequência }\end{array}$ & -Lipase & $\begin{array}{l}\text {-Cinamoil esterase } \\
\text { família1 } \\
\text {-Acetil xilana esterase }\end{array}$ & $\begin{array}{l}\text {-Clorogenato } \\
\text { esterase } \\
\text {-tanase }\end{array}$ & -Xilanase \\
\hline
\end{tabular}

Fonte: (FAZARY; JU, 2007)

Além dos dados apresentados na Tabela 4, também foi relatado que em farelo de trigo pré-solubilizado ou em modelos de compostos de dietil diéster, AnFaeA liberou 8-O-4' diferulato. A liberação de 8,5' diferulato (forma de benzofurano) tem sido demonstrada apenas por preparação comercial de Humicola insolens em resíduos de malte oriundos da produção de cerveja e por tanase de Aspergillus oryzae em composto de dietil diéster (FAULDS et al., 2002). 
As FAEs também diferem pelas suas características biofísicas e bioquímicas como massa molar, ponto isoelétrico e condições ótimas hidrolíticas de reação. A Tabela 4 mostra que as FAEs de origem microbiana exibem ampla faixa de $\mathrm{pH}$ e temperatura de ação, com as atividades ótimas ocorrendo entre $\mathrm{pH}$ 5 - 8 e entre $30^{\circ}-65^{\circ} \mathrm{C}$ (FAZARY; JU, 2007).

Tabela 4- Propriedades biofísico-químicas das feruloil esterases (FAEs).

\begin{tabular}{|c|c|c|c|c|c|c|}
\hline Micro-organismo & Enzima & $\begin{array}{l}\text { Tipo de } \\
\text { enzima }\end{array}$ & $\begin{array}{l}\text { Massa molar } \\
(\mathrm{kDa})\end{array}$ & $\begin{array}{l}\text { Ponto } \\
\text { isoelétrico }\end{array}$ & pH ótimo & $\begin{array}{l}\text { Termoestabilidade } \\
\left({ }^{\circ} \mathrm{C}\right)\end{array}$ \\
\hline $\begin{array}{l}\text { Clostridium } \\
\text { stercorarium }\end{array}$ & FAE & C,D & 33 & 6,5 & 8,5 & 65 \\
\hline $\begin{array}{l}\text { Clostridium } \\
\text { thermocellum }\end{array}$ & $\begin{array}{l}\text { XynZ,Xyn } \\
\text { Y }\end{array}$ & - & 45 & 5,8 & $5-8$ & 55 \\
\hline $\begin{array}{l}\text { Sporotrichum } \\
\text { thermophile }\end{array}$ & StFAE & $A, B, C$ & 33,23 & 3,5 & 6,0 & 55 \\
\hline $\begin{array}{l}\text { Streptomyces } \\
\text { olivochromogenes }\end{array}$ & FAE & - & 29 & 7,9 & 5,5 & 30 \\
\hline Aspergillus awamori & AwFAE & A & 37 & - & 7 & 45 \\
\hline Fusarium oxysporum & FoFAE & $A, B$ & 27,31 & 9,5 & 7 & $45-55$ \\
\hline Fusarium proliferatum & FAE & B & 31 & - & $6,5-7,5$ & 56 \\
\hline Neurospora crassa & FAE & $B, D$ & 35 & - & 6 & 55 \\
\hline Aspergillus nidulans & AnFAE & B & 56 & - & 7 & 45 \\
\hline $\begin{array}{l}\text { Aureobasidium } \\
\text { pullulans }\end{array}$ & FAE & B & 210 & 6,5 & 6,7 & 60 \\
\hline Aspergillus niger & FAE & $A, B$ & 36 & 3,$3 ; 3$ & 5 & 55 \\
\hline Piromyces & EstA & $\mathrm{D}$ & 55 & - & 6,7 & $50-60$ \\
\hline Cellvibrio japonicus & & & & & & \\
\hline Talaromyces stipitatus & TsFAE & $A, B, C$ & $35,35,65$ & 5,$3 ; 3,5 ; 4,6$ & $6-7$ & 60 \\
\hline Penicillium pinophilum & FAE & - & 57 & - & 6 & 55 \\
\hline Penicillium expansum & FAE & - & 65 & - & 5,6 & 37 \\
\hline Aspergillus sp. & FAE & - & 42 & - & 4,0 & 50 \\
\hline
\end{tabular}

Fonte: (FAZARY; JU, 2007)

\subsection{ACETIL ESTERASES}

Acetil xilana esterases (AcXEs) atuam clivando as ligações ésteres entre o ácido acético e as xilanas e já foram purificadas e caracterizadas de diversos fungos e bactérias incluindo Pseudomonas fluorescens, Butyrivibrio fibrisolvens, Streptomyces spp., Thermoanaerobacterium saccharolyticum, Caldocellum saccharolyticum, Thermomonospora fusca e Fibrobacter succinogenes (KOSEKI, 
et. al. 2006; SHAO; WIEGEL, 1995). Essas enzimas também foram classificadas em diferentes famílias de esterases de carboidratos (CE) através da classificação CAZy (POUVREAU et al., 2011). Essa classificação levou em consideração similaridades na sequência de aminoácidos e as famílias são numeradas de 1 a 13 (informações retiradas do banco de dados CAZY- Carbohydrate Active Enzymes) ${ }^{1}$.

A combinação de AcXEs com endo xilanase indicou que essas duas enzimas atuam de forma cooperativa, entretanto nem sempre é necessária a presença de xilanase para que a desacetilação da cadeia se inicie (KORMELINK, et. al. 1993). De acordo com Biely, 2012 existem dois mecanismos pelos quais as AcXEs podem atuar. O primeiro e mais comum é a desacetilação da posição 2 de um xilopiranosídeo através de uma sequência de 3 aminoácidos - serina, histidina e asparagina. Esse mecanismo primeiramente envolve a transferência do grupo acetil para uma hidroxila da serina através da formação de um intermediário tetraédrico instável. A liberação de álcool e do polissacarídeo desacetilado é seguido por hidrólise do intermediário. Esse mecanismo é idêntico ao utilizado por lipases e proteases do tipo serina (Figura 15). Em alguns casos, a asparagina encontrada na sequência de aminoácidos é substituída por glutamina e outras vezes a catálise da reação é realizada apenas por dois aminoácidos: serina e histidina.

'Informações acessadas no site <http://www.cazy.org em 05/10/2011. 
Figura 16- Mecanismo de ação de acetil xilana esterase utilizando uma sequência serina, histidina e asparagina (Ser-His-Asp) como catalizador da reação.

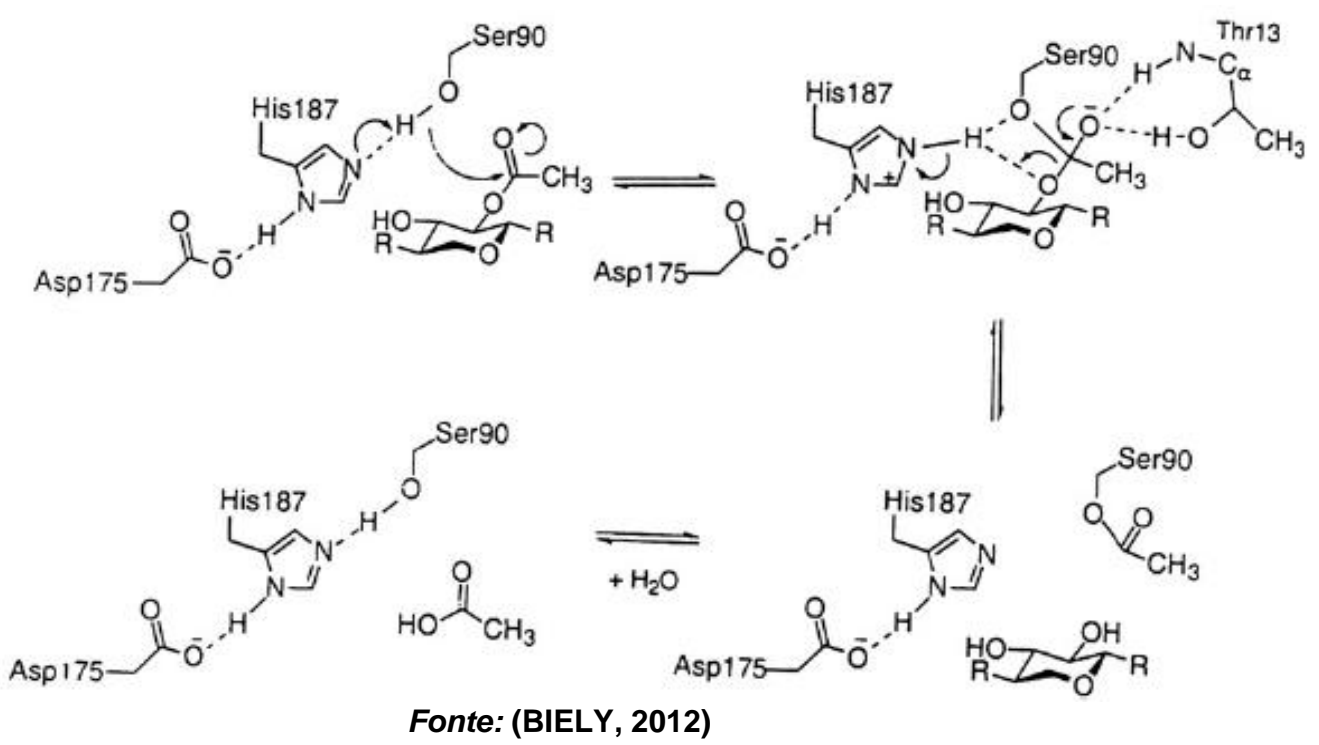

No outro mecanismo também descrito para a desacetilação de polissacarídeos, as enzimas são dependentes de metal e possuem um centro único de ligação à metais apresentando preferência por $\mathrm{Co}^{2+}$ (cobalto). Esse tipo de mecanismo prevalece nas acetil xilana esterases da família CE4. Juntamente com o metal, os resíduos de asparagina e histidina atuam como catalisadores para ativar a molécula de água que irá agir como um nucleófilo. Similarmente ao mecanismo anterior, a quebra da ligação envolve a formação de intermediário tetraédrico instável. A partir da hidrólise desse intermediário ocorre a desacetilação do polissacarídeo (Figura 16).

Figura 17- Mecanismo de ação de acetil xilana esterases que envolvem a participação de metais.
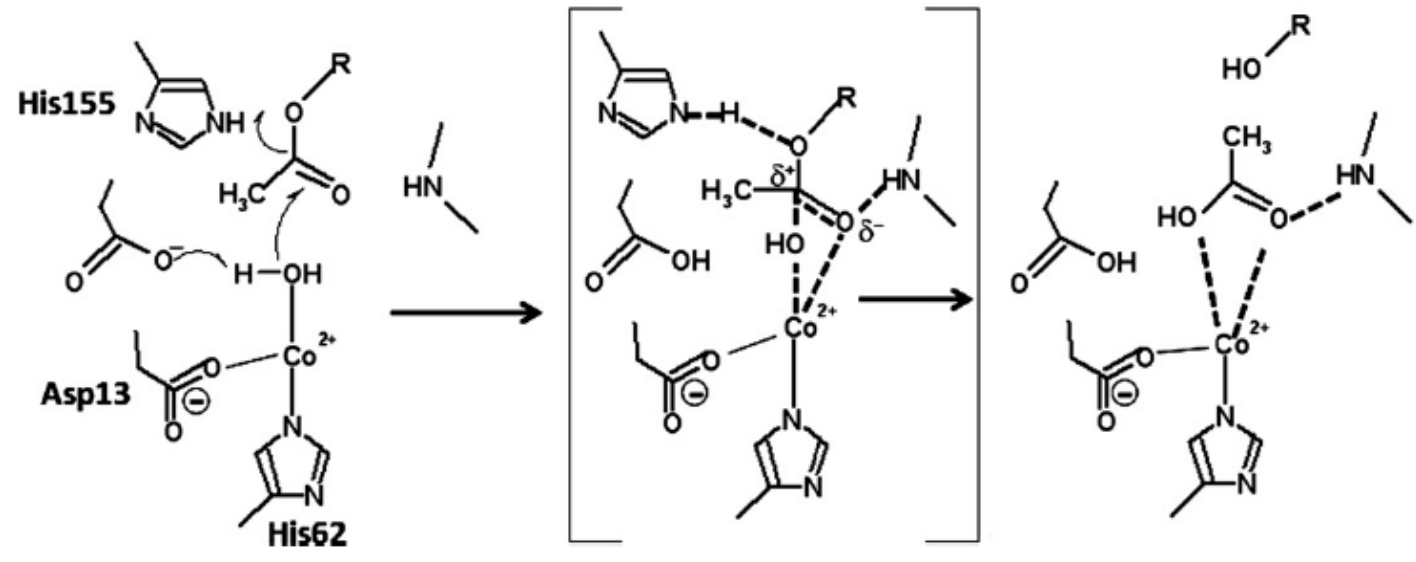

Fonte: (BIELY, 2012) 


\subsection{MÉTODOS DE DETERMINAÇÃO DA ATIVIDADE DE ESTERASES}

Existem alguns métodos descritos para determinação da atividade de esterases, dentre ele os métodos que utilizam cromatografia líquida de alta performance (HPLC), cromatografia gasosa e eletroforese capilar e métodos espectrofotométricos (FAZARY; JU, 2007).

Em HPLC é feita a análise de ácido ferúlico (AF) e cumárico (AC) liberados a partir da hidrólise de ésteres cinâmicos ou polissacarídeos de plantas ou materiais similares, entretanto requerem um equipamento caro para análise além de não serem adequados para análises rápidas para um grande número de amostras Também requerem $\mathrm{O}$ isolamento de substratos naturais, que é um procedimento demorado (FAZARY;JU, 2007). Os métodos espectrofotométricos detectam a quantidade de AF e AC liberado principalmente da hidrólise de seus metil ou etil ésteres (metil ferulato e cumarato ou etil ferulato e cumarato respectivamente). A deteç̧ão é baseada nas diferenças das propriedades espectrais entre AF livre e os substratos utilizados (RALET et al., 1994). Para ácido ferúlico o ensaio pode ser realizado utilizando o 4-nitrofenil ferulato como substrato, a detecção de ácido ferúlico é determinada a partir da quantidade de 4nitrofenol liberado, esse tipo de análise já foi realizada por Mccallum, Taylor e Towers (1991); e HEGDE, et. al. (2009). Cromatografia gasosa foi utilizada por Borneman, et. al. (1990), para determinação de AF a partir da hidrólise de metil ésteres e "bermuda grass" (Cynodon dactylon); essa técnica baseia-se na diferente distribuição das substâncias da amostra entre uma fase estacionária (sólida ou líquida) e uma fase móvel (gasosa). Donaghy e Mckay (1997) fizeram uso da técnica de eletroforese capilar para determinação de AF e AC provindos da hidrólise de seus metil ésteres e a partir do uso de FAXX (O-[ 5-O-(transferuloil)- $\alpha-L$-arabinofuranosil]-( $1 \rightarrow 3)-O-\beta-D-x i l o p i r a n o s i l-(1 \rightarrow 4)$-D-xilopiranose) e de PAXX ( O-[ 5-O-( (E)- p-cumaroil)- $\alpha$-L-arabinofuranosil]-(1 $\rightarrow 3)-O-\beta-D-$ xilopiranosil- (1 $\rightarrow 4)$-D-xilopiranose). A amostra da hidrólise contendo uma mistura iônica é introduzida em um capilar que está em um recipiente com tampão que irá conduzir corrente elétrica sob a influência de campo elétrico fazendo com que as 
espécies catiônicas migrem para o catodo e as aniônicas para o anodo, permitindo assim separar cada os componentes da mistura.

A atividade das acetil esterases atualmente são determinadas utilizando HPLC através da hidrólise de xilanas acetiladas como feito por Kormelink et al., (1993), utilizou xilana de "birchwood" ou métodos espectrofotométricos em sua maioria. Através de métodos espectrofotométricos é possível determinar a atividade de acetil xilanas em substratos cromogênicos ou fluorogênicos como 4nitrofenil acetato, utilizado por Kormelink et al., (1993) e Biely et al., (1985); $\alpha$ - ou $\beta$-naftil acetato utilizado por KOSEKI et al., (2006) ou 4-metilumbeliferil acetato utilizado por Shao e Wiegel (1995); (BIELY, 2012). Entretanto, as acetil esterases que são ativas com o uso desses substratos sintéticos não estão necessariamente ativas em polissacarídeos acetilados (KORMELINK et al., 1993).

\subsection{AMOSTRAS DE CANA-DE-AÇÚCAR E CARACTERÍSTICAS PREVIAMENTE CONHECIDAS}

Em um estudo prévio realizado em nosso laboratório (COSTA et. al., 2013), diversas frações do entrenó dos híbridos 58 e 89 desenvolvidos experimentalmente por pesquisadores da Universidade Federal de Viçosa ${ }^{2}$ e de um cultivar de referência foram caracterizados. Foram analisadas várias frações da cana como medula, interface medula-córtex, córtex e fração externa (Figura 17) e foi possível perceber que a medula é a região que apresenta maior teor de glucanas e menor teor de xilanas, bem como baixo teor de lignina (Tabela 5). Todas as frações foram submetidas à hidrólise enzimática com celulases comerciais e concluiu-se que a medula era a região menos recalcitrante, pois após 72 horas de reação foi possível obter altos rendimentos na conversão enzimática da celulose ( $78 \%$ no híbrido 58 e $85 \%$ no híbrido 89 ), enquanto que o córtex e a fração externa foram as mais recalcitrantes (Figura 18) mostrando a relação entre o baixo teor de lignina e a maior susceptibilidade à hidrólise. Além da relação entre lignina e recalcitrância, COSTA, et. al., (2013) também perceberam uma relação entre a quantidade de celulose disponível, quantidade de feixes vasculares e densidade do material.

\footnotetext{
${ }^{2}$ Projeto CNPq 552741/2007-8, coordenador Dr. Márcio Barbosa
} 
A partir desse trabalho, devido à baixa recalcitrância, a medula dos híbridos 58 e 89 foi selecionada para ser utilizada como um substrato lignocelulósico para avaliação da atividade de feruloil esterases. Além desses híbridos, uma cana de referência de maior teor de lignina também foi utilizada como parâmetro de comparação.

Figura 18- As quatro frações da cana-de-açúcar separadas. A) Fração externa; B ) Córtex; C) Interface medula-córtex; D) Medula.

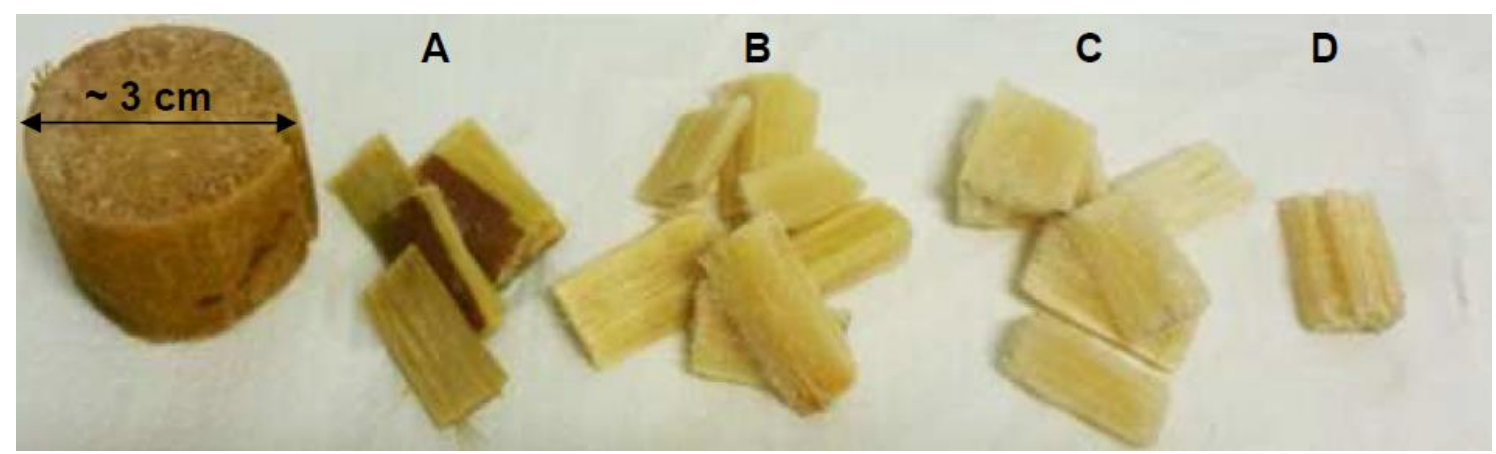

Fonte: COSTA et. al., 2013 
Tabela 5- Composição química das diversas frações do entrenó dos híbridos 58, 89 e do cultivar de referência (\%m/m).

\begin{tabular}{|c|c|c|c|c|c|c|c|c|c|}
\hline \multirow[t]{2}{*}{ Amostras } & \multirow{2}{*}{$\begin{array}{l}\text { Região do } \\
\text { entrenó }\end{array}$} & \multicolumn{8}{|c|}{ Composição química $(\%, \mathrm{~m} / \mathrm{m})$} \\
\hline & & Extrativos* $^{*}$ & Glucanas* $^{\star}$ & Xilanas $^{\star}$ & Arabinosil $^{*}$ & Acetill* $^{*}$ & $\begin{array}{c}\text { Lignina } \\
\text { total }^{\star}\end{array}$ & $\begin{array}{l}\text { Lignina } \\
\text { insolúvel* }\end{array}$ & $\begin{array}{l}\text { Lignina } \\
\text { solúvel* }\end{array}$ \\
\hline Cana de & Medula & $2,9 \pm 0,2^{a}$ & $49,3 \pm 0,1^{a}$ & $15,4 \pm 0,2^{\text {a }}$ & $1,5 \pm 0,01^{\mathrm{a}}$ & $2,4 \pm 0,2^{\text {a }}$ & $17,2 \pm 0,2^{a}$ & $14,8 \pm 0,1^{\text {a }}$ & $2,4 \pm 0,1^{\text {a }}$ \\
\hline \multirow[t]{3}{*}{ referência } & Interface & $3,0 \pm 0,1^{a}$ & $43,8 \pm 0,1^{b}$ & $18,8 \pm 0,1^{b}$ & $1,4 \pm 0,1^{b}$ & $3,2 \pm 0,1^{b}$ & $22,1 \pm 0,3^{b}$ & $20,4 \pm 0,1^{b}$ & $2,4 \pm 0,3^{a}$ \\
\hline & Córtex & $1,3 \pm 0,1^{b}$ & $42,0 \pm 0,5^{c}$ & $20,4 \pm 0,2^{c}$ & $1,1 \pm 0,1^{c}$ & $3,0 \pm 0,2^{b, c}$ & $21,9 \pm 0,3^{b}$ & $19,8 \pm 0,1^{\mathrm{c}}$ & $2,0 \pm 0,3^{a}$ \\
\hline & F. externa & $3,1 \pm 0,1^{\mathrm{a}}$ & $42,4 \pm 0,5^{b, c}$ & $19,6 \pm 0,2^{d}$ & $1,2 \pm 0,1^{\mathrm{c}}$ & $2,6 \pm 0,2^{a, c}$ & $22,3 \pm 0,2^{b}$ & $20,4 \pm 0,1^{b}$ & $1,9 \pm 0,2^{a}$ \\
\hline Hibrido & Medula & 2,30 & $53,2 \pm 1,9^{a}$ & $16,2 \pm 0,4^{a}$ & $1,5 \pm 0,1^{a}$ & $2,8 \pm 0,3^{a}$ & $12,6 \pm 0,3^{a}$ & $10,3 \pm 0,2^{a}$ & $2,6 \pm 0,2^{a}$ \\
\hline \multirow[t]{3}{*}{58} & Interface & 3,70 & $46,9 \pm 0,7^{\mathrm{b}}$ & $19,9 \pm 0,3^{b}$ & $1,5 \pm 0,05^{a, b}$ & $3,9 \pm 0,1^{b}$ & $15,5 \pm 0,3^{b}$ & $13,4 \pm 0,3^{b}$ & $2,8 \pm 0,1^{a}$ \\
\hline & Córtex & 3,30 & $43,1 \pm 1,2^{c}$ & $21,9 \pm 0,8^{c}$ & $1,3 \pm 0,1^{b}$ & $3,6 \pm 0,1^{b, c}$ & $19,0 \pm 0,7^{c}$ & $16,1 \pm 0,1^{c}$ & $3,1 \pm 0,1^{b}$ \\
\hline & F. externa & 3,30 & $43,0 \pm 0,7^{c}$ & $21,3 \pm 0,5^{c}$ & $1,1 \pm 0,04^{c}$ & $3,4 \pm 0,1^{c}$ & $20,2 \pm 0,4^{d}$ & $18,3 \pm 0,3^{d}$ & $2,5 \pm 0,1^{\mathrm{a}}$ \\
\hline Hibrido & Medula & 3,05 & $54,7 \pm 0,2^{a}$ & $13,9 \pm 0,2^{a}$ & $0,8 \pm 0,00^{a}$ & $2,1 \pm 0,2^{a}$ & $13,5 \pm 0,02^{a}$ & $12,0 \pm 0,1^{a}$ & $1,9 \pm 0,1^{a, b}$ \\
\hline \multirow[t]{3}{*}{89} & Interface & 3,21 & $49,9 \pm 0,3^{b}$ & $16,9 \pm 0,2^{b}$ & $1,3 \pm 0,02^{b}$ & $2,4 \pm 0,3^{a}$ & $14,5 \pm 0,2^{b}$ & $12,8 \pm 0,1^{b}$ & $2,2 \pm 0,2^{b}$ \\
\hline & Córtex & 2,90 & $48,7 \pm 0,3^{c}$ & $19,5 \pm 0,2^{c}$ & $0,7 \pm 0,04^{a}$ & $2,4 \pm 0,4^{\mathrm{a}}$ & $18,7 \pm 0,1^{c}$ & $17,4 \pm 0,1^{c}$ & $1,9 \pm 0,2^{a, b}$ \\
\hline & F. externa & 2,13 & $46,9 \pm 0,4^{d}$ & $20,7 \pm 0,4^{d}$ & $0,7 \pm 0,01^{a}$ & $2,1 \pm 0,1^{\mathrm{a}}$ & $20,4 \pm 0,3^{d}$ & $19,6 \pm 0,3^{d}$ & $1,7 \pm 0,03^{\circ}$ \\
\hline
\end{tabular}

$\left({ }^{*}\right)$ Médias de cada dado em um mesmo híbrido seguidas de letras iguais não diferem entre si a $95 \%$ de confiança. 
Figura 19- Conversão enzimática da celulose em diferentes frações do entrenó da cana híbrida. A) Híbrido 58; B) Híbrido 89

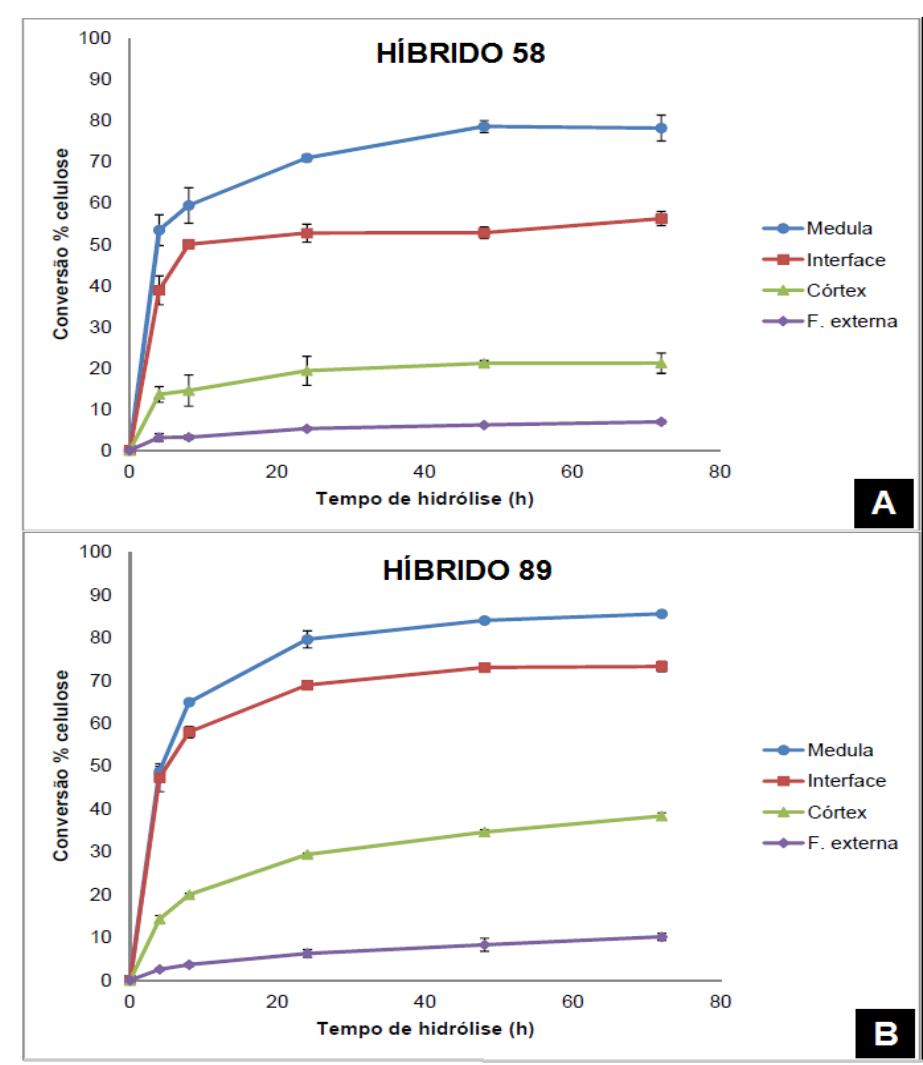

Fonte: COSTA et. al., 2013

\subsection{CONSIDERAÇÕES FINAIS SOBRE A REVISÃO BIBLIOGRÁFICA}

A atividade de algumas esterases importantes na hidrólise do material lignocelulósico, como feruloil e acetil esterases é tradicionalmente determinada utilizando substratos sintéticos. Como esses substratos não possuem as características de um material lignocelulósico, as atividades obtidas a partir desses ensaios não podem ser equiparadas com as atividades reais dessas enzimas agindo diretamente sobre um substrato complexo.

A fim de desenvolver um método capaz de representar como essas enzimas atuam sobre um material lignocelulósico, foram associadas as informações sobre a recalcitrância estudada em diversas regiões de um entrenó de cana de açúcar com a possibilidade de preparar um substrato útil para determinar a atividade de feruloil esterases. 


\section{OBJETIVOS:}

O presente trabalho tem como objetivo desenvolver um método apropriado para determinar a atividade de feruloil esterases utilizando um material lignocelulósico como substrato.

Para atingir o objetivo do trabalho, as seguintes etapas foram cumpridas:

$\checkmark$ Preparação e caracterização química da medula de cana de açúcar;

$\checkmark$ Preparo de um substrato lignocelulósico mais susceptível à hidrólise por esterases através do emprego de um pré-tratamento da medula com celulase comercial;

$\checkmark$ Uso dos substratos descritos anteriormente para avaliar a atividade de três tipos diferentes de feruloil esterases;

$\checkmark$ Avaliação se há diferença significativa de eficiência de conversão dos ésteres em estudo quando o substrato é preparado a partir de híbridos de cana de açúcar que contrastam para o teor de lignina; 


\section{MATERIAIS E MÉTODOS}

\subsection{AMOSTRAS DE CANA DE AÇÚCAR E PREPARO DA MEDULA}

A medula foi obtida a partir de híbridos experimentais de cana de açúcar identificados por numeração própria (58 e 89) conforme descrito anteriormente (COSTA et al., 2013), além de um híbrido usado comercialmente identificado como cultivar RB855156 (RB). Os híbridos em questão foram plantados em Julho de 2010 por propagação vegetativa num campo experimental aberto localizado na Escola de Engenharia de Lorena, Departamento de Biotecnologia, com espaçamento entre covas de $3 \times 3 \mathrm{~m}$. As plantas foram irrigadas em períodos de seca prolongada. $\mathrm{O}$ solo de cada cova foi suplementado com $100 \mathrm{~g}$ de calcário dolomítico e $100 \mathrm{~g}$ de adubo NPK 4:14:8 cinco meses após o plantio e novamente suplementado com $100 \mathrm{~g}$ de adubo NPK 4:14:8 sete meses após o plantio. O primeiro corte foi feito em Julho de 2011 (plantas com 18 meses de cultivo, correspondendo, portanto, a plantas maduras de cana de açúcar) e o segundo corte foi feito após 12 meses do rebrotamento do primeiro corte, em Agosto de 2012, também correspondendo a plantas maduras. As plantas do segundo corte foram empregadas no presente estudo. Os caules foram devidamente numerados, os 2 primeiros entrenós desde a base e os 2 últimos desde o topo foram descartados, as pontas seladas com filme de PVC e então armazenados a $18^{\circ} \mathrm{C}$ até o momento de uso.

Os nós dos caules foram descartados e os entrenós cortados inicialmente em fragmentos com cerca de 2,5 a $3 \mathrm{~cm}$ no sentido longitudinal. Cada um destes fragmentos teve a sua região central recuperada com o auxílio de um furador de rolhas de $0,9 \mathrm{~cm}$ de diâmetro interno. Esta fração central foi denominada de medula da cana. Para remoção de sacarose contida nas frações da medula, os fragmentos foram submetidos à extração em Soxhlet com água destilada por aproximadamente 5 ciclos de 8 a 10 horas cada um, até que não houvesse açúcar significativo presente na água de extração. O teor de açúcares totais presentes na água de extração foi determinado através do método do fenol-ácido sulfúrico, que consiste na adição de $2,5 \mathrm{~mL}$ de ácido sulfúrico concentrado e 25 $\mu \mathrm{L}$ de fenol $80 \%$ a $1 \mathrm{~mL}$ de amostra; a ausência de cor indicou ausência de sacarose. Posteriormente, os fragmentos foram secos ao ar e moídos em moinho 
com malha de 20 Mesh. O material moído foi armazenado para as etapas subsequentes do trabalho.

\subsection{PREPARO DO SUBSTRATO POR DIGESTÃO DA MEDULA COM CELULASES COMERCIAIS}

A medula descrita no item 3.2.1 foi submetida a uma pré-digestão para degradação da celulose e obtenção de um material menos recalcitrante. Os ensaios foram realizados em Erlenmeyers de 2 litros nos quais foram colocados aproximadamente $6 \mathrm{~g}$ de medula seca ao ar, $10 \mathrm{FPU}$ de celulase comercial (Celluclast) por grama de medula e tampão citrato $50 \mathrm{mM}$ até se obter um volume final de $300 \mathrm{ml}$ de reação. A mistura foi submetida à agitação contínua a $120 \mathrm{rpm}$ e $45^{\circ} \mathrm{C}$ por 4 horas. $\mathrm{O}$ sólido obtido foi lavado com $100 \mathrm{ml}$ de tampão citrato 50 $\mathrm{mM}$ e $200 \mathrm{ml}$ de água destilada e seco ao ar até atingir cerca de 10\% de umidade. Esse sólido foi denominado como "substrato" e foi estocado para análises posteriores como sua caracterização e submissão à hidrólise com esterases comerciais.

\subsection{DETERMINAÇÃO DA COMPOSIÇÃO QUÍMICA DAS AMOSTRAS}

\subsubsection{DETERMINAÇÃO DE POLISSACARÍDEOS E LIGNINA}

Aproximadamente $3,0 \mathrm{~g}$ da medula sem sacarose ou de "substrato" foram pesados no interior de sacos de papel de filtro. Em paralelo, a umidade de uma amostra de cerca de 1,0 $\mathrm{g}$ deste mesmo material foi determinada para se calcular a massa seca de material submetido à extração. As amostras contidas nos sacos de papel de filtro foram submetidos à extração em aparelho de Soxhlet com etanol $95 \%$ por $6 \mathrm{~h}$. O material extraído foi seco ao ar e pesado. Em paralelo, a umidade de uma amostra de cerca de 1,0 $\mathrm{g}$ deste mesmo material foi determinada para se calcular a massa seca de material extraído. A diferença entre as massas secas, com e sem extrativos, foi utilizada para a determinação do teor de extrativos (FERRAZ et al., 2000). As amostras extraídas com etanol foram então pesadas em um tubo de ensaio (aproximadamente $0,3 \mathrm{~g}$ ) e tratadas com $3 \mathrm{~mL}$ de ácido sulfúrico $72 \%(\mathrm{p} / \mathrm{p})$ em banho a $30{ }^{\circ} \mathrm{C}$ durante 1 hora. Em seguida, o líquido 
obtido foi transferido para Erlenmeyers de $250 \mathrm{~mL}$ com adição de $79 \mathrm{~mL}$ de água destilada e autoclavado a $120^{\circ} \mathrm{C} / 1$ atm por $1 \mathrm{~h}$. O material foi resfriado e filtrado a vácuo em filtro $n^{\circ} 3$ SCHOTT. O sólido obtido foi seco em estufa a $100^{\circ} \mathrm{C}$ até atingir massa constante para determinação de lignina insolúvel. A lignina solúvel foi determinada a partir do filtrado por espectrofotometria no UV-visível a $205 \mathrm{~nm}$,

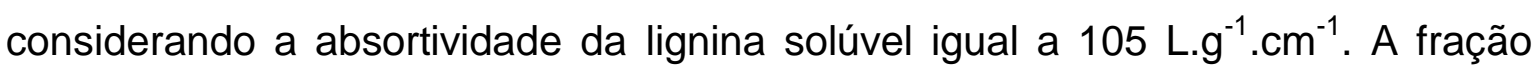
solúvel foi ainda filtrada em SepPack C18 e analisada por cromatografia líquida de alta performance (HPLC) em coluna BioRad HPX-87H a $45{ }^{\circ} \mathrm{C}$, para determinar o teor de açúcares e ácido acético presentes. A fase móvel utilizada foi ácido sulfúrico $0,005 \mathrm{~mol} \mathrm{~L}^{-1}$ e o fluxo de $0,6 \mathrm{ml} / \mathrm{min}$.

\subsubsection{DETERMINAÇÃO DE ÁCIDOS HIDROXICINÂMICOS}

Para determinar o teor de ácidos hidróxicinâmicos (ácido p-cumárico e ácido ferúlico), amostras de medula livre de extrativos e de "substrato" (não extraído com etanol 95\%) foram tratadas em um meio alcalino sob condições brandas para quantificar os ácidos ligados à hemicelulose e a lignina através de ligações éster e em meio alcalino sob condições mais severas para quantificar os ácidos totais unidos à matriz lignocelulósica através de ligação éster e/ou éter (LAM; STONE, 1994; MASARIN et al., 2011).

A reação em condição branda foi realizada em Erlenmeyers de $50 \mathrm{ml}$ onde $50 \mathrm{mg}$ de massa seca das amostras foram adicionados juntamente com $5 \mathrm{ml}$ de $\mathrm{NaOH} 1 \mathrm{~mol} \mathrm{~L}^{-1}$ e submetidos à agitação contínua de $120 \mathrm{rpm}$ a $30^{\circ} \mathrm{C}$ por 24 horas. A mistura obtida foi acidificada com $\mathrm{HCl} 6 \mathrm{~mol} \mathrm{~L}^{-1}$ até atingir $\mathrm{pH} 2 \mathrm{e}$ avolumada em balão volumétrico de $10 \mathrm{ml}$. A mistura foi estocada a $4^{\circ} \mathrm{C}$ por 16 horas e então filtrada em membrana de 0,45 $\mu \mathrm{m}$ para análise de ácido ferúlico e p-cumárico por HPLC.

A reação em condição severa foi realizada em reatores de aço inoxidável 316 a $170^{\circ} \mathrm{C}$ por 2 horas onde $200 \mathrm{mg}$ de massa seca das amostras foram adicionados juntamente com $16 \mathrm{ml}$ de $\mathrm{NaOH} 4 \mathrm{~mol} \mathrm{~L}^{-1}$ e $2 \mathrm{mg}$ de antraquinona. A mistura obtida foi resfriada, acidificada com $\mathrm{HCl} 6 \mathrm{~mol} \mathrm{~L}^{-1}$ até atingir $\mathrm{pH} 2 \mathrm{e}$ avolumada em balão volumétrico de $100 \mathrm{ml}$. A mistura foi estocada a $4^{\circ} \mathrm{C}$ por 16 horas e então filtrada em membrana de 0,45 $\mu \mathrm{m}$ para análise de ácido ferúlico e p-cumárico por HPLC. 
Todas os ensaios foram realizados em triplicatas. A quantificação dos ácidos fenólicos foi feita em HPLC utilizando uma coluna Hypersil, ThermoScientific com uma fase móvel composta por acetonitrila: água (1:4) contendo $1 \%$ de ácido acético. O fluxo utilizado foi de $0,8 \mathrm{ml} / \mathrm{min}$ e os ácidos hidroxicinâmicos foram detectados por detector UV fixado em $315 \mathrm{~nm}$.

\subsection{REAÇÕES DE HIDRÓLISE DOS SUBSTRATOS COM ESTERASES}

As hidrólises foram realizadas utilizando $50 \mathrm{mg}$ de substrato (base massa seca) em $5 \mathrm{ml}$ de tampão citrato de sódio $50 \mathrm{mM} \mathrm{pH} \mathrm{6,3} \mathrm{e} \mathrm{quantidades} \mathrm{de} \mathrm{feruloil}$ esterase variáveis. Foram utilizadas três feruloil esterases diferentes: feruloil esterase recombinante de rúmen de um micro-organismo produzida pela Megazyme ${ }^{\circledR}(E F A E-R U)$; domínio de feruloil esterase de xilanase de Chlostridium thermocellum também obtida da Megazyme ${ }^{\circledR}$ (EFAEZCT) e feruloil esterase A produzida a partir de uma levedura recombinante Pichia pastoris e doada por Aniko Varnai (VTT, Finlândia). As cargas de enzima adicionadas nos meios reacionais foram estabelecidas com base no teor de proteínas totais de cada formulação. $O$ teor de proteínas totais nas formulações foi determinado com base no método de Bradfrod (1976). A determinação foi feita pela mistura de $100 \mu \mathrm{l}$ da preparação enzimática e $1 \mathrm{ml}$ do reagente de Bradford. A mistura foi homogeneizada e após 5 minutos a absorbância da solução foi medida em 595 $\mathrm{nm}$. O teor de proteínas nas amostras foi determinado a partir de uma curva de calibração externa feita com albumina bovina como padrão. Os teores de proteínas totais nas formulações avaliadas foram: $0,5 \mathrm{mg} / \mathrm{ml}$ de formulação contendo feruloil esterase de rúmen; $4,35 \mathrm{mg}$ de proteína/ml de formulação contendo feruloil esterase de Clostridium thermocellum e; $2,4 \mathrm{mg}$ de proteína/grama de preparado liofilizado em feruloil esterase A.

Os ensaios de hidrólise foram realizados em tubos de Falcon® de $15 \mathrm{ml}$. Os tubos foram colocados em banho a $40^{\circ} \mathrm{C}$. Em tempos pré-definidos de reação, os tubos foram retirados do banho e resfriados por $5 \mathrm{~min}$ em banho de gelo com a finalidade de parar a reação enzimática. Em seguida, todo o conteúdo foi centrifugado a $3400 \times \mathrm{g}$ por 20 minutos a $4^{\circ} \mathrm{C}$ e $100 \mu \mathrm{l}$ do sobrenadante foi recolhido para análise em HPLC para a determinação dos ácidos ferúlico e cumárico, seguindo metodologia descrita no item 3.3.2. Após a centrifugação e a 
amostragem (ambos à frio) os tubos foram recolocados no banho e o tempo de reação foi novamente computado. Amostragens similares foram feitas ao longo de todo o período de reação avaliado em cada caso.

Um grupo de experimentos de hidrólise dos substratos por esterases também foi realizado empregando $1 \mathrm{mg}$ de albumina do soro bovino (BSA) por $\mathrm{ml}$ da solução de reação enzimática. Neste caso o estudo foi feito com os substratos preparados a partir das medulas dos híbridos 58 e 89.

Experimentos controle sem a adição de enzima também foram realizados para determinar os níveis de ácidos hidróxicinâmicos liberados a partir dos substratos, mesmo sem catálise enzimática. Para isso, cada um dos substratos foi incubado em um meio reacional em que a solução de enzima foi substituída por água. Os teores de ácidos ferúlico e cumárico liberados nestas reações ao longo de 48 h variaram entre 0 e 0,015\%. Gráficos da \% de ácido hidróxicinâmico formado versus o tempo de reação permitiram definir linhas de tendência que melhor definiam o comportamento da reação na ausência da enzima. Através da equação que melhor descrevia a linha de tendência, foi possível estimar os níveis de hidrólise na ausência da enzima. Os percentuais de hidrólise enzimática foram descontados da hidrólise ocorrida na ausência de enzimas em cada tempo de amostragem.

\subsubsection{AJUSTE DO MÉTODO DE HIDRÓLISE DO SUBSTRATO COM ESTERASES}

Ensaios adicionais foram realizados avaliando 0 procedimento de tratamento em banho de ebulição ou a adição de ácido acético ao meio reacional como formas de interromper a catálise enzimática antes da amostragem para quantificação dos ácidos hidroxicinâmicos. A reação com parada por tratamento em banho em ebulição foi realizada com o substrato 58 e EFAE-RU nas mesmas condições de $\mathrm{pH}$ e temperatura descritas no item 3.4, usando cargas enzimáticas de 0,$01 ; 0,025 ; 0,05$ e $0,075 \mu g$ de proteína/g de substrato. A reação se deu por 5 minutos e então as amostras foram colocadas em banho de água em ebulição por 5 minutos. Após o aquecimento, a amostra foi centrifugada a 3400 x g por 20 min e uma amostra do sobrenadante foi analisada quanto aos teores de ácido ferúlico por HPLC. A reação com parada pela adição de ácido acético foi feita com o 
substrato $89 \mathrm{com}$ apenas uma carga enzimática $(0,05 \mu \mathrm{gg}$ de proteína/g de substrato) nas mesmas condições de $\mathrm{pH}$ e temperatura descritas no item 3.4. Após 5 minutos de reação, $2 \mathrm{ml}$ de ácido acético glacial foram adicionados aos 5 $\mathrm{ml}$ de reação e então a amostra centrifugada a $3400 \times \mathrm{g}$ por 20 min e uma amostra do sobrenadante foi analisada quanto aos teores de ácido ferúlico por HPLC. A proporção de ácido acético utilizado foi baseada no trabalho de FAULDS et al., (2002).

\subsection{DEFINIÇÃO DE UM PROTOCOLO GERAL PARA A DETERMINAÇÃO DA ATIVIDADE ENZIMÁTICA DE FERULOIL ESTERASES}

Após avaliar a influência da carga enzimática na conversão do substrato e das eventuais formas de interromper as reações em tempos definidos de amostragem, novos testes foram realizados a fim de definir um método geral que permitisse determinar a atividade das enzimas utilizadas na região efetiva de velocidade máxima de reação, seguindo um modelo experimental similar ao método de determinação da atividade de celulase em papel de filtro (Ghose,1987). Neste caso, o tempo de reação foi fixado em $5 \mathrm{~min}$, a forma de interromper a reação foi o resfriamento em banho de gelo por $5 \mathrm{~min}$ e a amostragem foi feita após centrifugação a $3400 \times \mathrm{g}$ a $4^{\circ} \mathrm{C}$ por $20 \mathrm{~min}$. Este procedimento foi realizado com cargas variáveis de enzimas a fim de definir a carga enzimática necessária para a conversão dos ésteres de ácido ferúlico numa faixa próxima a $2 \%$. Idealmente, o método foi ajustado para gerar dois dados de conversão maiores do que $2 \%$ e dois dados menores do que $2 \%$. A carga exata de enzima necessária para a conversão de $2 \%$ foi então determinada graficamente por interpolação dos dados gerados. Como substratos diferentes foram avaliados no presente trabalho, os teores inicias de éster do ácido ferúlico eram variáveis (Tabela 10). Desta forma, a conversão de $2 \%$ dos ésteres de ácido ferúlico presentes nos $50 \mathrm{mg}$ iniciais de substrato de cada ensaio correspondeu à formação de 3,6; 3,8 e 4,6 $\mu \mathrm{g}$ de ácido ferulico para os híbridos 58, 89 e RB, respectivamente.

Com os dados de teor de ácido ferúlico nos hidrolisados enzimáticos foram montados gráficos relacionando a massa de ácido ferúlico liberada em solução 
(expressa em $\mu \mathrm{g}$ ) versus o logaritmo da carga enzimática empregada em cada ensaio (expressa em $\mu \mathrm{g}$ de proteína/kg de substrato). A equação da reta obtida foi usada para determinar a carga exata de enzima necessária para proporcionar uma conversão de $2 \%$ de ésteres em 5 min de reação.

A demonstração do cálculo necessário para determinar a atividade enzimática é ilustrada a seguir para o híbrido 58.

Base do cálculo: considerando que no substrato $58,0,36 \%$ da massa é de ácido ferúlico, a quantidade de $\mu$ moles de ácido ferúlico (AF) liberados em 5 min de reação que correspondam a $2 \%$ de conversão = 3,6 $\mu \mathrm{g} / 194,18$ (massa molar do $\mathrm{AF})=0,01854$ umoles $/ 5 \mathrm{~min}$, ou 0,003708 $\mu$ moles $/ \mathrm{min}$.

Determinação experimental da carga enzimática para a hidrólise demandada: $3,708 \times 10^{-3} \mu$ moles/min (UI) são gerados por uma carga de enzima (CE) determinada experimentalmente por interpolação.

$\mathrm{CE}$, presente no tubo de reação (expressa em $\mu \mathrm{g}$ de proteína) $=[\mathrm{CE}(\mu \mathrm{g}$ de proteína/kg de substrato) $\times 50 \times 10^{-6}$ ( $\mathrm{kg}$ de substrato no ensaio)]

Portanto: $3,708 \times 10^{-3} \mathrm{UI}$ de esterase estão contidos em CE (expresso em $\mu \mathrm{g}$ de proteína).

Atividade específica $(A E)=3,708 \times 10^{-3} / C E$ (expresso em $\mu g$ de proteína) $=A E$ (expressa em UI/ $\mu$ g de proteína)

Atividade no preparado comercial líquido $=A E x$ conc de proteína $(\mathrm{mg} / \mathrm{mL})=$ Atividade (expressa em $\mathrm{UI} / \mathrm{mL}$ de preparado comercial).

\subsection{INFLUÊNCIA DO pH E TEMPERATURA NA CONVERSÃO DO SUBSTRATO}

Foram feitos novos ensaios para determinar a influência da temperatura e $\mathrm{pH}$ na atividade enzimática. Inicialmente, foi feita a hidrólise do substrato 58 com EFAE-RU nas cargas de 0,01;0,025;0,05;0,075 e 0,1 $\mu \mathrm{g}$ de proteína/g de substrato por 5 minutos nas condições descritas em 3.4 e testando-se as temperaturas de 25,40 e $60^{\circ} \mathrm{C}$. Posteriormente novos ensaios de 5 minutos foram realizados a uma temperatura fixa de $40^{\circ} \mathrm{C}$ e mesmas condições do ensaio anterior, mas em pHs diferentes $(, 5 ; 5,5 ; 6,3$ e 7,2 ). 


\section{RESULTADOS E DISCUSSÃO}

O presente trabalho envolveu três etapas básicas de estudo que visaram desenvolver uma metodologia adequada e inédita de determinação da atividade de feruloil esterases. Para isso, a medula de três híbridos distintos de cana de açúcar foram preparadas e caracterizadas quanto à composição química. As medulas foram então submetidas a uma pré digestão com celulases comercias a fim de gerar um resíduo sólido enriquecido em hemicelulose que fosse adequado para uso como substrato para feruloil esterases. Uma vez preparado e caracterizados estes substratos, foi desenvolvida uma metodologia experimental que permitisse determinar a atividade de feruloil esterases tendo o substrato preparado a partir de medula de cana como foco de estudo.

\subsection{COMPOSIÇÃO QUÍMICA DA MEDULA DOS ENTRENÓS DE CANA- DE - AÇÚCAR}

Após a remoção preliminar de sacarose, a medula dos híbridos 58, 89 e RB foi submetida à extração em Soxlet com etanol $95 \%(\mathrm{v} / \mathrm{v})$ para a quantificação de extrativos e à hidrólise ácida para a determinação de sua composição química (Tabela 6). A medula das 3 amostras avaliadas apresentou proporção elevada de glucanas e baixa de lignina quando comparada com a composição química de bagaços de cana dos mesmos cultivares (Masarin et al., 2011). Este era um resultado esperado, visto que a medula dos entrenós apresenta maior proporção de células de parênquima que são menos lignificadas do que as fibras e vasos (mais abundantes na região do córtex do entrenó) (SIQUEIRA et al., 2011; COSTA et al., 2013).

Costa et al. (2013) caracterizou a medula de dois dos híbridos em questão (58 e 89), porém oriundos de uma outra safra de cana. Os valores obtidos foram cerca de $13 \%$ de lignina e $53-54 \%$ de glucana. Isso permite afirmar que a composição química da medula dos híbridos em estudo se manteve constante em dois ciclos de corte da cana, pois os híbridos utilizados no presente trabalho são de um corte posterior ao utilizado por Costa et al. (2013). 
A medula da cana de referência $(\mathrm{RB})$ apresentou maior teor de lignina (19\%) e menor teor de glucana (42\%) e foi usada para comparar os resultados entre substratos com teores variados de lignina.

Para a determinação dos ácidos hidroxicinâmicos, a medula dos híbridos 58 e 89 e referência RB foi submetida a dois tipos de tratamento alcalino: a) um tratamento alcalino brando para a retirada dos ácidos hidroxicinâmicos ligados à lignina e/ou às metilglucurono-arabino-xilanas por ligações do tipo éster e; b) um tratamento alcalino severo para a retirada de todos os ácidos hidroxicinâmicos, incluindo aqueles que se ligam à lignina por ligação do tipo éter (Tabela 7). Foi possível observar maior quantidade de ácido cumárico do que ácido ferúlico na medula das três amostras. Costa et al (2013) detectaram maiores teores destes ácidos na medula dos híbridos 58 e 89 de uma safra de cana anterior à utilizada nesse trabalho. Isso indica que, apesar da composição de polissacarídeos e de lignina ter se mantido a mesma em dois ciclos de corte da cana, a quantidade dos ésteres presentes não se manteve constante. A medula de RB apresentou teores de ácido ferúlico similares aos de 58 e 89. Entretanto, a quantidade de ácido cumárico foi significativamente mais elevada, seguindo a mesma tendência observada para o maior teor de lignina presente na medula desta cana. Este resultado também era esperado, visto que parte da lignina detectada nas amostras é decorrente da presença dos ácidos hidroxicinâmicos (RALPH et al., 1994; MASARIN et al., 2011).

Tabela 6- Composição química da medula de entrenós de diferentes híbridos de cana de açúcar (\%, m componente/m medula, base seca).

\begin{tabular}{ccccccc}
\hline Híbrido & Glucana & Xilana & Arabinosil & Acetil & Lignina & $\begin{array}{c}\text { Fração } \\
\text { solúvel em } \\
\text { etanol }\end{array}$ \\
58 & $49,5 \pm 0,9$ & $16,8 \pm 0,3$ & $2,61 \pm 0,02$ & $3,1 \pm 0,2$ & $13,0 \pm 0,3$ & $2,3 \pm 0,3$ \\
89 & $51,9 \pm 0,2$ & $14,9 \pm 0,2$ & $2,21 \pm 0,04$ & $2,2 \pm 0,1$ & $12,8 \pm 0,5$ & $2,3 \pm 0,2$ \\
RB & $42 \pm 1$ & $19,6 \pm 0,6$ & $2,14 \pm 0,06$ & $3,4 \pm 0,2$ & $19,1 \pm 0,1$ & $2,5 \pm 0,3$ \\
\hline
\end{tabular}


Tabela 7- Composição de ácidos hidroxicinâmicos da medula de entrenós de diferentes híbridos de cana de açúcar (\%, m componente/m medula, base seca).

\begin{tabular}{lcccc}
\hline Híbrido & Ácido ferúlico & Ácido cumárico & Ácido ferúlico & Ácido cumárico \\
\cline { 2 - 5 } & \multicolumn{2}{c}{ Tratamento brando } & \multicolumn{1}{c}{ Tratamento severo } \\
\hline 58 & $0,47 \pm 0,02$ & $1,97 \pm 0,06$ & $1,31 \pm 0,05$ & $4,11 \pm 0,06$ \\
89 & $0,35 \pm 0,01$ & $1,17 \pm 0,03$ & $1,21 \pm 0,01$ & $2,82 \pm 0,03$ \\
RB & $0,54 \pm 0,04$ & $3,1 \pm 0,2$ & $1,53 \pm 0,02$ & $6,9 \pm 0,3$
\end{tabular}

$\left(^{*}\right)$ Os teores mostrados para os ácidos hidróxicinâmicos foram determinados em material livre de extrativos e recalculados para material incluindo extrativos.

\subsection{DIGESTÃO DA MEDULA COM CELULASES E PREPARO DE UM SUBSTRATO ADEQUADO À DETERMINAÇÃO DA ATIVIDADE DE ESTERASES}

Siqueira et al. (2011) analisaram a susceptibilidade da medula e do córtex de uma variedade comercial de cana-de-açúcar à digestão por uma mistura de enzimas celulolíticas. Os autores observaram que na medula houve $63 \%$ de conversão da celulose, enquanto que no córtex houve apenas $20 \%$. Os dados foram correlacionados com a ocorrência de células menos lignificadas na região da medula (células de parênquima). Um trabalho posterior de Costa et al. (2013) confirmou a mesma tendência de maior digestibilidade da região de medula em 3 diferentes híbridos de cana de açúcar, dois dos quais são avaliados no presente trabalho (58 e 89). A mesma tendência de maior digestibilidade da região de medula em outras plantas do grupo das gramíneas foi reportado por Zeng et. al. (2011) para o talo do milho. Com estes antecedentes, as medulas das canas em estudo foram submetidas a um tratamento prévio com celulases comerciais por 4 horas para retirada parcial da celulose, a fim de se obter um material rico em hemicelulose e mais susceptível à ação das esterases. A medula pré-digerida com celulases foi então avaliada como um substrato potencial para a determinação das atividades de esterases.

O resíduo sólido da digestão com celulases foi lavado com água e seco ao ar por 2 dias. Após a secagem, observou-se a formação de grumos que apresentavam estrutura mais fofa nos substratos 58 e RB e mais rígida no 89. A cor também diferiu entre as amostras, sendo que os substratos 58 e RB foram mais claros do que o 89. O rendimento de sólidos após o tratamento com 
celulases foi de $85,5 \%, 62,6 \%$ e $96,7 \%$ para os híbridos 58,89 e $R B$, respectivamente. Os sólidos foram então submetidos à extração em Soxlet com etanol 95\% (v/v) para a remoção e quantificação de extrativos e submetidos à hidrólise com ácido para determinação da sua composição química (Tabela 8). Após a extração com etanol, foi observada uma elevada perda de massa em todas as amostras que correspondeu a 18,9\%, 18,6\% e 19\% nos híbridos 58, 89 e RB, respectivamente. Esses valores foram muito elevados e não devem representar a quantidade real de extrativos presentes no substrato. Devido à remoção parcial de celulose pela ação das celulases e eventualmente hemicelulose, já que as celulases comerciais apresentam atividade xilanolítica (PESSOTI, 2013; Tabela 11), o sólido residual deve apresentar uma estrutura colapsada. Logo, resíduos de oligossacarídeos de xilana bem como oligossacarídeos de glucana insolúveis em água a frio, porém possivelmente solúveis na extração à quente com etanol $95 \%$ devem ter sido solubilizados, justificando assim os valores elevados obtidos. Os sólidos obtidos apresentaram ainda um baixo teor de glucanas devido à ação das celulases (Tabela 8).

Tabela 8- Composição química dos sólidos resultantes da digestão com celulases da medula de entrenós de diferentes híbridos de cana de açúcar (\%, m componente/m medula, base seca).

\begin{tabular}{ccccccc}
\hline Híbrido & Glucana & Xilana & Arabinosil & Acetil & Lignina & $\begin{array}{c}\text { Fração solúvel em } \\
\text { etanol }\end{array}$ \\
58 & $26,7 \pm 0,1$ & $15,1 \pm 0,1$ & $1,74 \pm 0,01$ & $2,7 \pm 0,1$ & $15,9 \pm 0,1$ & $18,9 \pm 0,9$ \\
89 & $27,9 \pm 0,2$ & $15,6 \pm 0,1$ & $1,54 \pm 0,04$ & $2,4 \pm 0,1$ & $20,1 \pm 0,2$ & $19 \pm 2$ \\
RB & $27,7 \pm 0,7$ & $14,3 \pm 0,4$ & $1,46 \pm 0,02$ & $2,5 \pm 0,2$ & $15,7 \pm 0,2$ & $19 \pm 2$ \\
\hline
\end{tabular}

Tabela 9- Teor de ácidos hidroxicinâmicos nos sólidos resultantes da digestão com celulases da medula de entrenós de diferentes híbridos de cana de açúcar (\%, m componente/m medula, base seca).

\begin{tabular}{lcccc}
\hline Híbrido & Ácido ferúlico & \multicolumn{1}{c}{ Ácido cumárico } & Ácido ferúlico & Ácido cumárico \\
\hline \multicolumn{2}{r}{ Tratamento brando } & \multicolumn{2}{c}{ Tratamento severo } \\
\hline 58 & $0,36 \pm 0,04$ & $2,2 \pm 0,2$ & $1,31 \pm 0,06$ & $4,9 \pm 0,4$ \\
89 & $0,38 \pm 0,01$ & $2,0 \pm 0,1$ & $1,54 \pm 0,04$ & $4,7 \pm 0,1$ \\
RB & $0,46 \pm 0,01$ & $3,0 \pm 0,2$ & $1,3 \pm 0,1$ & $6,0 \pm 0,5$
\end{tabular}

(*) Os teores mostrados para os ácidos hidróxicinâmicos foram determinados em material não submetido à pré-extração com etanol 95\%. 
Para melhor visualizar a eventual remoção de ácidos hidroxicinâmicos decorrentes do tratamento da medula com as celulases comerciais, foi calculado o balanço de massa para a reação com cada híbrido estudado. Os dados estão mostrados na Tabela 10. Através desse balanço de massas foi possível perceber que o ácido cumárico liberado por hidrólise alcalina severa e branda permaneceu praticamente constante nos substratos 58 e 89 quando comparado com a medula sem tratamento. $\mathrm{Na}$ amostra $\mathrm{RB}$, houve um pequeno decréscimo na massa de ácido cumárico liberado por hidrólise severa. Estes dados sugerem que 0 ácido cumárico estaria predominantemente ligado à lignina uma vez que a digestão da medula com celulases comerciais não deveria afetar a lignina do material. Por outro lado, a quantidade de ácido ferúlico provindo da hidrólise branda diminuiu nos substratos 58 e 89 e praticamente permaneceu inalterada no RB. Essa diminuição pode indicar que as celulases comerciais também atuaram nas ligações glicosídicas presentes na hemicelulose e consequentemente podem ter clivado frações hemicelulósicas nas quais os ácidos ferúlicos se encontravam esterificados. O resultado obtido é coerente, visto que a celulase utilizada apresenta atividades de xilanase e $\beta$-xilosidase (Tabela 11).

Tabela 10- Balanço de massas para o processo de digestão da medula com celulases comerciais.

\begin{tabular}{|c|c|c|c|c|}
\hline \multicolumn{5}{|c|}{ m de componente/100g de medula original } \\
\hline \multirow[t]{2}{*}{ Híbrido } & AF & $A C$ & AF & $A C$ \\
\hline & \multicolumn{2}{|c|}{ Trat. brando } & \multicolumn{2}{|c|}{ Trat. severo } \\
\hline $58 \mathrm{NT}$ & $0,48 \pm 0,02$ & $2,0 \pm 0,1$ & $1,34 \pm 0,05$ & $4,2 \pm 0,1$ \\
\hline $58 \mathrm{TC}$ & $0,31 \pm 0,04$ & $1,9 \pm 0,2$ & $1,12 \pm 0,05$ & $4,2 \pm 0,3$ \\
\hline 89 NT & $0,36 \pm 0,01$ & $1,2 \pm 0,1$ & $1,23 \pm 0,01$ & $2,9 \pm 0,1$ \\
\hline 89 TC & $0,24 \pm 0,01$ & $1,3 \pm 0,1$ & $0,96 \pm 0,03$ & $2,9 \pm 0,1$ \\
\hline RB NT & $0,55 \pm 0,04$ & $3,1 \pm 0,2$ & $1,56 \pm 0,02$ & $7,0 \pm 0,3$ \\
\hline RB TC & $0,45 \pm 0,01$ & $2,9 \pm 0,1$ & $1,3 \pm 0,1$ & $5,8 \pm 0,5$ \\
\hline
\end{tabular}

*NT: não tratado; TC: tratado com celulase. 
Tabela 11- Dados das atividades presentes na celulase comercial empregada na digestão da medula (PESSOTI, 2013).

\begin{tabular}{|c|c|c|c|c|c|c|}
\hline $\begin{array}{l}\text { Enzima } \\
\text { Comercial }\end{array}$ & $\begin{array}{c}\text { FPAse } \\
\left.\text { (FPU'mL }^{-1}\right)\end{array}$ & $\begin{array}{l}\text { CMCase } \\
\left(\text { Ul.mL }^{-1}\right)\end{array}$ & $\begin{array}{c}\beta- \\
\text { Glicosidase } \\
\left(\text { Ul.mL } \mathrm{mL}^{-1}\right)\end{array}$ & $\begin{array}{c}\text { CBH } \\
\left(\mathrm{Ul}^{-1} \mathrm{~mL}^{-1}\right)\end{array}$ & $\begin{array}{l}\text { Xilanase } \\
\left(\text { Ul.mL }^{-1}\right)\end{array}$ & $\begin{array}{c}\beta- \\
\text { Xilosidase } \\
\left(\text { Ul.mL } \mathrm{mL}^{-1}\right)\end{array}$ \\
\hline $\begin{array}{c}\text { Sigma } \\
\text { C2730 } \\
\text { (Celluclast) }\end{array}$ & 45,2 & 549,1 & 77,0 & 101,0 & 485,0 & 29,0 \\
\hline
\end{tabular}

\subsection{HIDRÓLISE DO SUBSTRATO ORIUNDO DA MEDULA DE CANA- DE- AÇÚCAR COM FERULOIL ESTERASES}

A medula de cana pré-digerida com celulases (preparada e caracterizada conforme descrito nos itens anteriores) foi empregada em uma série de experimentos visando avaliar sua adequação como um substrato lignocelulósico modelo para a determinação da atividade enzimática de feruloil esterases. A detecção dos ácidos ferúlico e cumárico foi feita em HPLC e, através das áreas dos picos observados nos cromatogramas (Figura 19), foi possível calcular a concentração de ácido ferúlico e cumárico liberados após o tratamento com feruloil esterase. 
Figura 20- Cromatogramas do hidrolisado de um substrato preparado a partir da medula do híbrido de cana 58. A hidrólise ilustrada empregou E-FAE-RU numa carga de enzima equivalente a $25 \mu \mathrm{g}$ de proteínas/g de substrato após 2 horas de reação.

*AF: ácido ferúlico; AC: ácido cumárico.
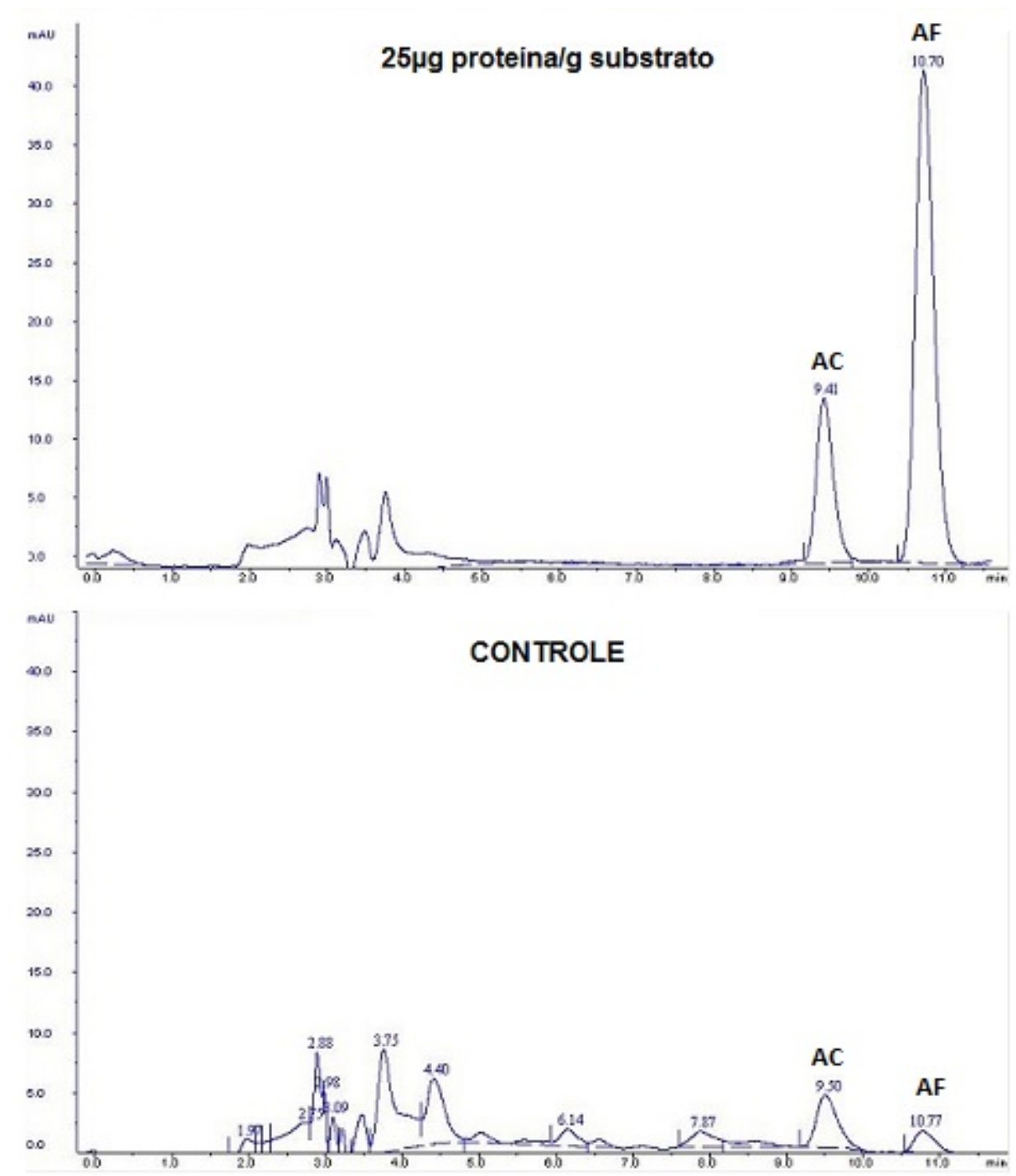

O primeiro grupo de experimentos empregou duas feruloil esterases diferentes, ambas comercializadas pela empresa Megazyme®: a) proveniente de rúmen (E-FAERU) e, b) proveniente de Clostridium thermocellum (E-FAEZCT). Os substratos avaliados foram aqueles preparados a partir da medula dos híbridos 58 e 89 que apresentavam menor recalcitrância (COSTA et al., 2013).

A Figura 20 mostra que a ação das feruloil esterases de rúmen proporcionaram níveis máximos de conversão de ácido ferúlico de 14\% e 7,2\% nos substratos preparados a partir dos híbridos 58 e 89, respectivamente. 
Figura 21- Formação de ácido ferúlico durante o tratamento dos substratos com feruloil esterase de rúmen por tempos de reação de até $48 \mathrm{~h}$. As figuras foram divididas em tempos curtos (até 120 min) e longos (até 48h) de reação para melhor visualização da cinética de hidrólise. Substratos preparados a partir das medulas dos híbridos 58 (A) e 89 (B).

Condições de reação: Tampão citrato de sódio $50 \mathrm{mM}, \mathrm{pH}$ 6,3, 40ํㅜ; carga de enzima equivalente a $25 \mu \mathrm{g}$ de proteína/g de substrato.

A
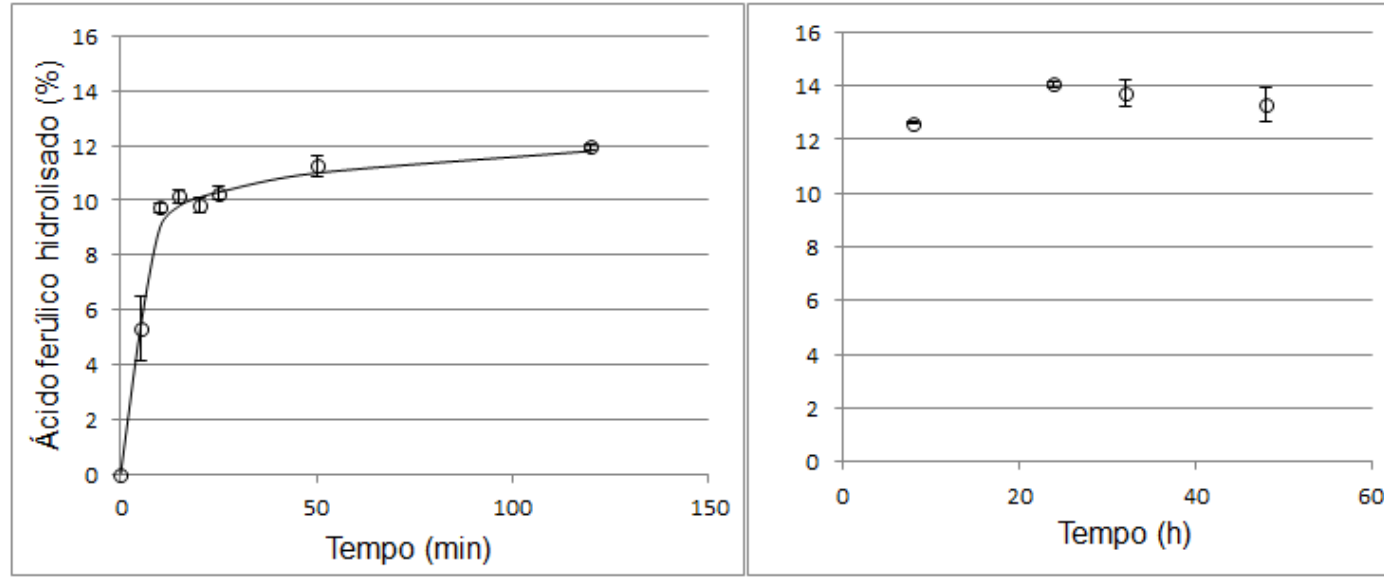

B
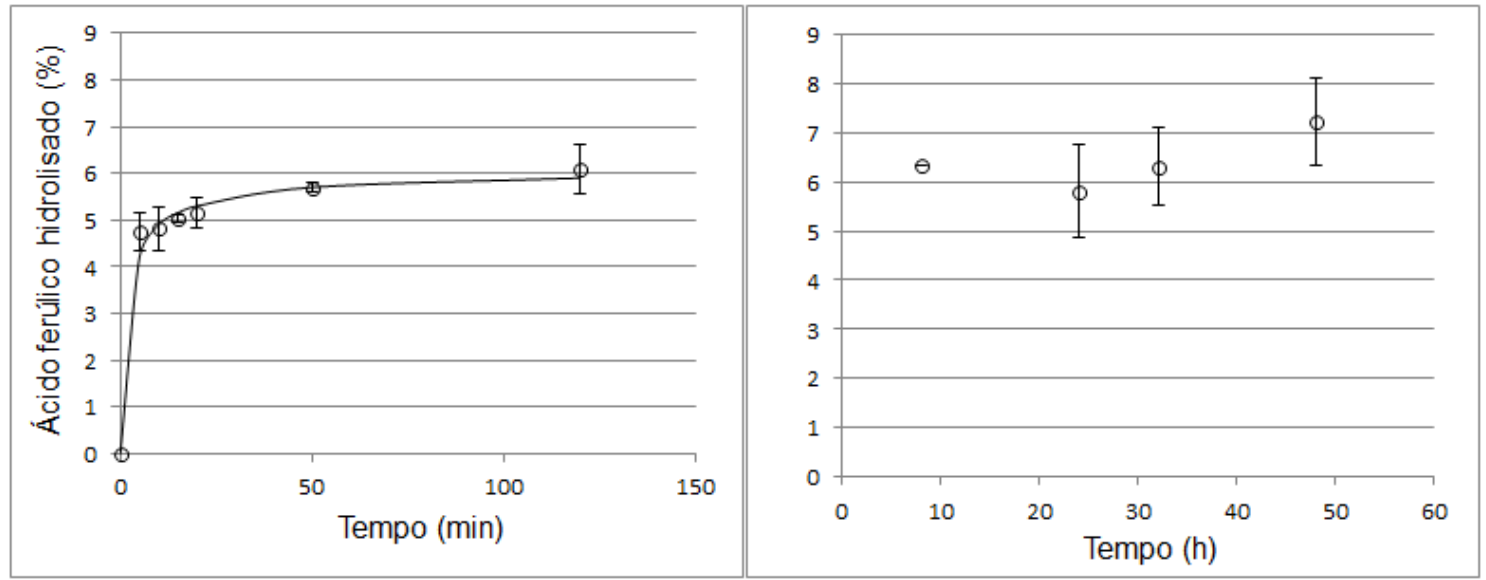

Um teste utilizando feruloil esterase de Clostridium thermocellum e o substrato preparado a partir do híbrido 58, empregando a mesma carga proteica dos ensaios anteriores ( $25 \mu \mathrm{g}$ de proteína/g do substrato), mostrou que os maiores níveis de conversão dos ésteres de ácido ferúlico foram de 11,5\% após 48 horas de reação (Figura 21). 
Figura 22- Formação de ácido ferúlico durante o tratamento do substrato preparado a partir do híbrido $58 \mathrm{com}$ feruloil esterase de Clostridium thermocellum por tempos de reação de até $48 \mathrm{~h}$. As figuras foram divididas em tempos curtos (até $120 \mathrm{~min}$ ) e longos (até 48h) de reação para melhor visualização da cinética de hidrólise.

Condições de reação: Tampão citrato de sódio $50 \mathrm{mM}, \mathrm{pH}$ 6,3, 40ํㅜ; carga de enzima equivalente a $25 \mu \mathrm{g}$ de proteína/g de substrato.

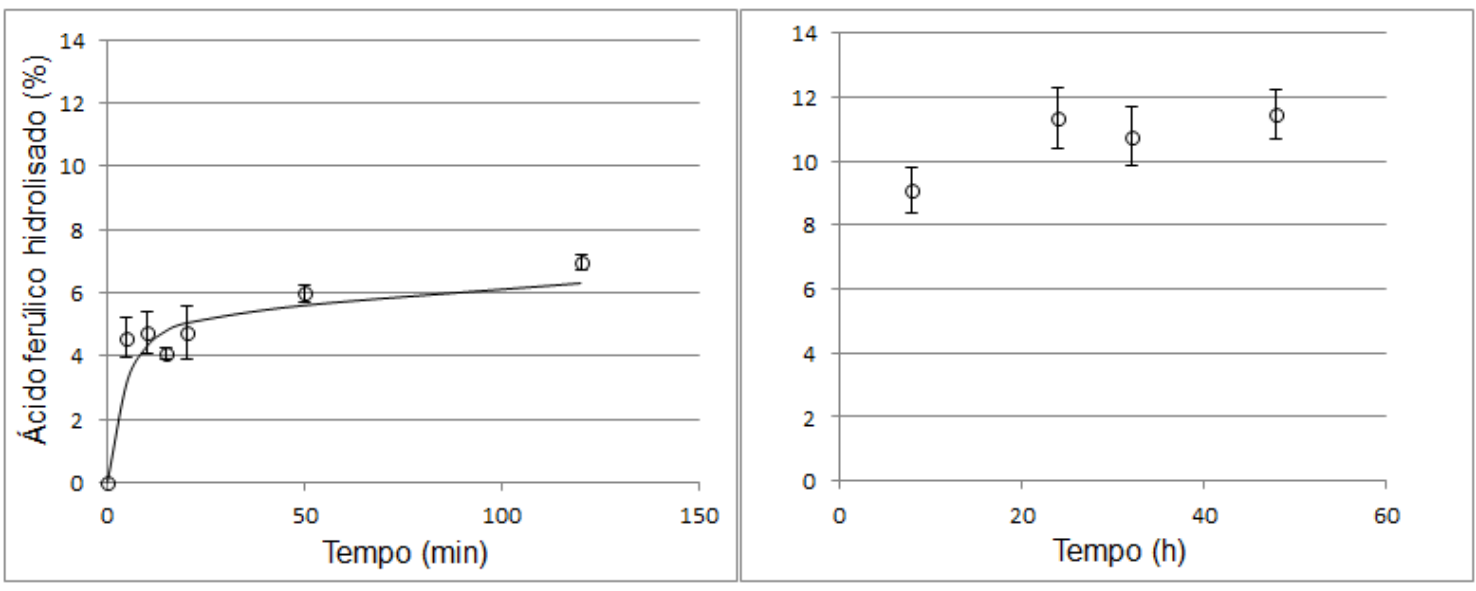

Nos três experimentos descritos anteriormente também houve hidrólise de ésteres de ácido cumárico. No entanto, menos do que 1-2\% do total de ésteres presentes nas amostras foi hidrolisado e o nível de hidrólise não foi progressivo com o tempo de reação. A porcentagem de hidrólise foi baixa quando comparada com aquela observada para os ésteres de ácido ferúlico (Figuras 20 e 21). Vale ressaltar que o teor total de ésteres de ácido cumárico presente nas amostras é significativamente maior do que os de ácido ferúlico (6 vezes maior no híbrido 58 e 5 vezes maior para o híbrido 89). A ponderação destes dados sugere que uma pequena parcela dos ésteres de ácido cumárico também são hidrolisados pelas enzimas usadas, mas que esta hidrólise não progride com o tempo de reação. Esta observação poderia ser explicada por uma hidrólise rápida de ésteres de ácido cumárico ligados à hemicelulose (que seriam minoritários) e que o restante dos ésteres deste ácido estariam ligados à lignina, não sendo reconhecidos pelas feruloil esterases.

Os níveis máximos de conversão de ácido ferúlico descritos anteriormente são comparáveis aos descritos em outros trabalhos. Por exemplo, Ralet et al. (1994) observaram a liberação de $12,2 \%$ de ácido ferúlico após 30 minutos de hidrólise quando o substrato usado era metil ferulato. Neste caso, nota-se que um substrato não-lignocelulósico foi mais rapidamente hidrolizado. Já Borneman et al. 
(1990) descreveram a liberação de 8,5 a 12,2\% de ácido ferúlico após 24 horas de hidrólise e de 21,4 a 31,6\% após 48 horas quando empregaram "bermuda grass" (Cynodon dactylon) como substrato e feruloil esterases provenientes de 5 fungos diferentes. Um trabalho de Faulds et al. (2002) mostrou que a combinação das feruloil esterases com diversas glicosil hidrolases geram intensidades de hidrólise variáveis, sugerindo ação sinérgica entre elas. No caso da hidrólise de resíduo de malte incubado com uma mistura de feruloil esterase de Aspergillus niger (AnFAEA) e xilanase por $3 \mathrm{~h}$, a quantidade de ácido ferúlico liberada foi de $23 \%$.

Os dados obtidos no presente trabalho para a hidrólise do éster de ácido ferúlico em função do tempo de reação mostram que a reação apresentou uma velocidade inicial bastante elevada e decai significativamente após 10 min para atingir os patamares de conversão de cerca de 13\% e 6\% com feruloil esterase de rúmen para o substrato 58 e 89, respectivamente e para 11,5\% com feruloil esterase de Clostridium thermocellum para o substrato 58. Este padrão cinético é característico de reações catalisadas por enzimas em situações em que não há grande excesso de substrato ou ainda em situações em que o produto de reação inibe fortemente a ação da enzima (NELSON; COX, 2011). Considerando que a reação em estudo ocorre em duas fases (substrato insolúvel e enzima solúvel), o padrão cinético observado pode ainda ser decorrente da existência de ésteres inacessíveis na estrutura insolúvel do substrato.

Uma outra possibilidade para explicar o padrão cinético observado seria decorrente de uma inativação da enzima ao longo da reação. Em muitos casos, o uso de aditivos ao meio reacional como albumina bovina (BSA), Dimetilsulfóxido (DMSO) e glicerol permitem aumentar a estabilidade da enzima de interesse (IYER et. al., 2008). Uma vez que o fabricante da feruloil esterase de rúmen (Megazyme®) recomenda o uso de albumina bovina (BSA) nos ensaios enzimáticos, os substratos oriundos dos híbridos 58 e 89 foram tratados com EFAE-RU por 2 horas na presença de $1 \mathrm{mg}$ de BSA $/ \mathrm{ml}$. A carga de EFAE-RU foi variável na faixa de 12,5; 25; 50 e $100 \mu \mathrm{g}$ de proteína/g de substrato (Figura 22). Os dados indicam que não houve nenhuma diferença significativa na conversão do substrato o que levou à decisão de realizar todos os ensaios posteriores na ausência de BSA. 
Figura 23- Comparação da hidrólise enzimática dos substratos 58 (A) e 89 (B) na ausência e na presença de BSA $(1 \mathrm{mg} / \mathrm{mL})$.

Condições de reação: Tampão citrato de sódio $50 \mathrm{mM}, \mathrm{pH} 6,3,40^{\circ} \mathrm{C}, 2$ horas de reação. Carga de enzima (EFAE-RU) equivalente a 12,5, 25, 50, e $100 \mu \mathrm{g}$ de proteína/g de substrato.

A

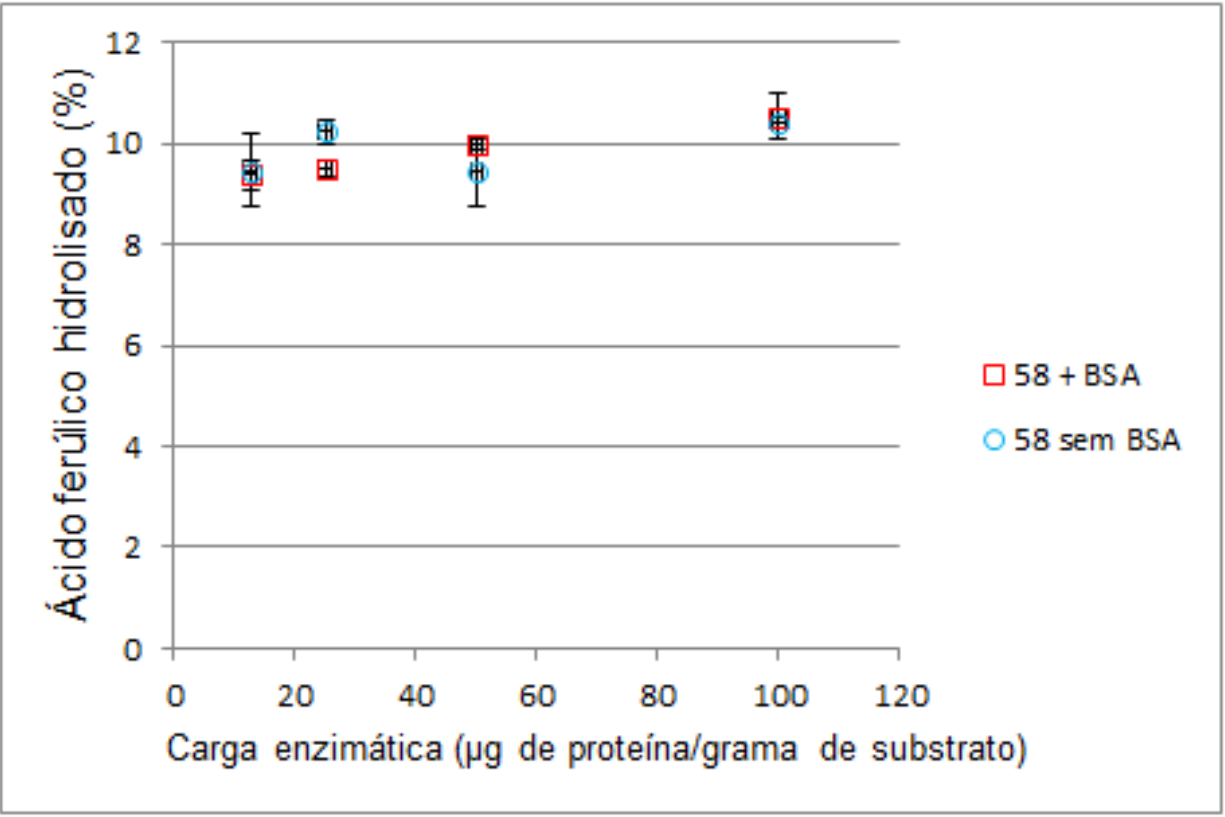

B

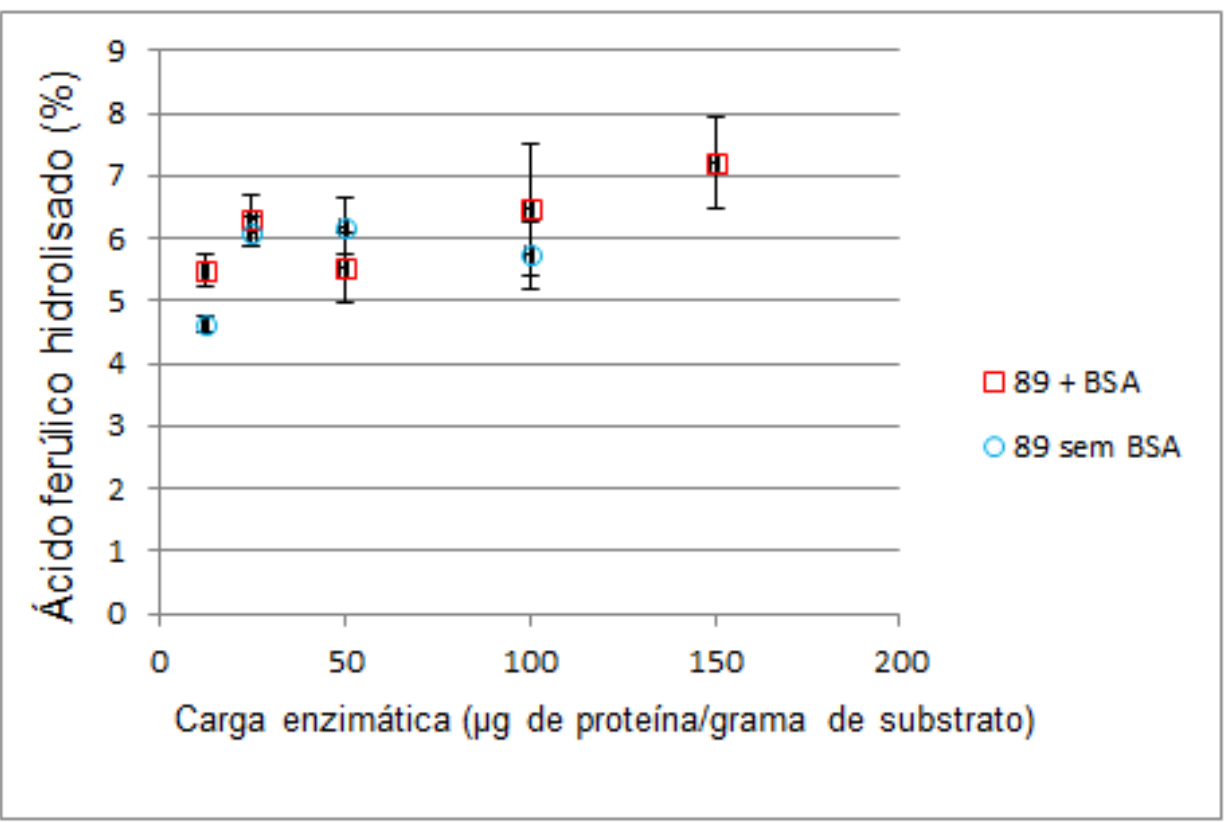




\subsection{AJUSTE DO MÉTODO PARA DETERMINAÇÃO DA ATIVIDADE DE FERULOIL ESTERASES}

Para empregar os ensaios de digestão descritos anteriormente como um método adequado para determinar a atividade das enzimas em estudo é possível utilizar duas abordagens para o tratamento de dados. A abordagem tradicional, empregada para substratos solúveis no meio reacional é graficar o número de moles (ou umoles) de produto de reação (ácido ferúlico) formados em função do tempo de reação e então traçar a tangente da curva obtida para calcular a velocidade inicial de reação que pode representar a velocidade máxima de reação, situação na qual é possível determinar a atividade enzimática (ENGEL; HAMES \& RICKWOOD, 1996). Outra abordagem possível para determinar a atividade enzimática a partir dos dados descritos é empregar diluições sucessivas da enzima e fixar um tempo de reação representativo da região da cinética onde a velocidade de reação deve ser máxima. Neste caso, o teor de produto formado é quantificado em um tempo fixo e com isso pode haver uma maior reprodutibilidade experimental, mesmo em tempos curtos de reação (GHOSE, 1987).

Como os experimentos anteriores demonstraram que a velocidade de reação era elevada e que a mesma decaia logo após os primeiros minutos de reação, novos experimentos foram realizados utilizando cargas menores de enzima (1; 2 e $5 \mu \mathrm{g}$ de proteína/grama de substrato) a fim de verificar se seria possível estimar a velocidade inicial de reação com um maior número de dados experimentais. As cargas crescentes de enzima proporcionaram conversões finais de éster do ácido ferúlico crescentes, mas as velocidades iniciais de reação ainda foram elevadas e pouco diferiram entre as cargas ensaiadas (Figura 23). 
Figura 24- Ácido ferúlico liberado após 48 horas de reação utilizando 1; 2 e $5 \mu \mathrm{g}$ de proteína/g de substrato 58 e EFAE-RU

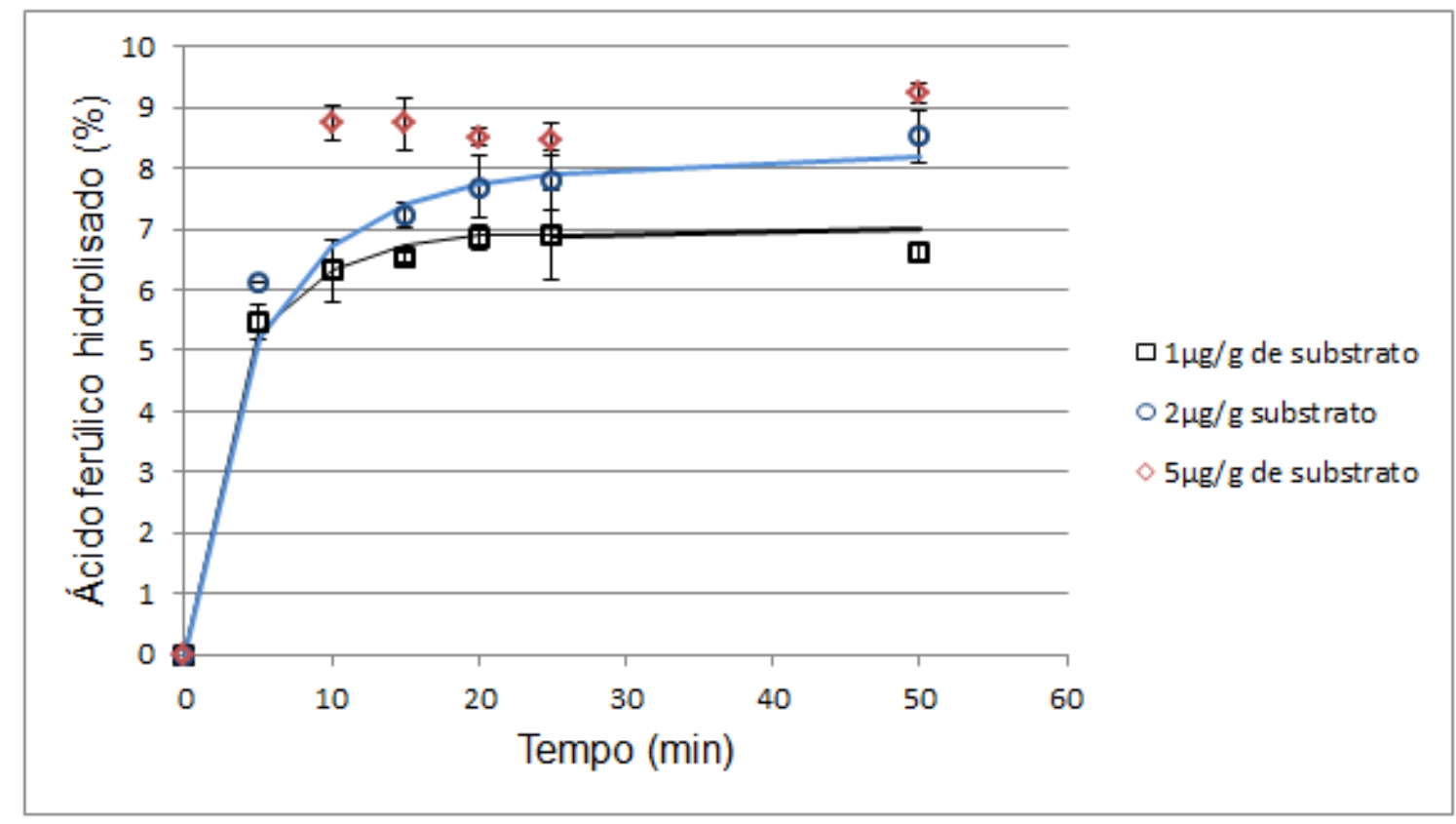

Cargas ainda menores de enzima foram então empregadas $(0,01 ; 0,05 ; 0,1$ e $0,5 \mu \mathrm{g}$ de proteína/g de substrato), gerando os dados mostrados na Figura 24. Nestas cargas de enzima foi possível observar conversões que variaram de $0,5 \%$ a 2,8\% nos 5 primeiros minutos de reação e velocidades iniciais de reação de $0,09 \% \cdot \min ^{-1}, 0,6 \% \cdot \mathrm{min}^{-1}, 0,4 \% \cdot \mathrm{min}^{-1}$ e $1,2 \% \cdot \mathrm{min}^{-1}$, respectivamente. A divisão das velocidades iniciais pelas respectivas cargas enzimáticas empregadas sobre $1 \mathrm{~g}$ de substrato gerou os dados a seguir: $9 \% \cdot \mathrm{min}^{-1} / \mu \mathrm{g}$ de proteína, $12 \% \cdot \mathrm{min}^{-1} / \mu \mathrm{g}$ de proteína, $4 \% \cdot \mathrm{min}^{-1} / \mu \mathrm{g}$ de proteína e $2,4 \% \cdot \mathrm{min}^{-1} / \mu \mathrm{g}$ de proteína, respectivamente. Os dados sugerem que a velocidade máxima de reação foi da ordem de 9-

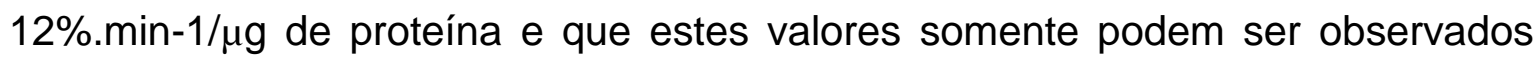
nos estágios iniciais da hidrólise quando a conversão do éster em ácido é da ordem de $1-2 \%$ (Figura 24). 


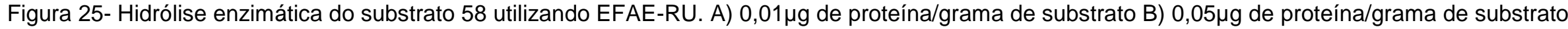
C) $0,1 \mu \mathrm{g}$ de proteína/grama de substrato D) $0,5 \mu \mathrm{g}$ de proteína/grama de substrato.

A

B
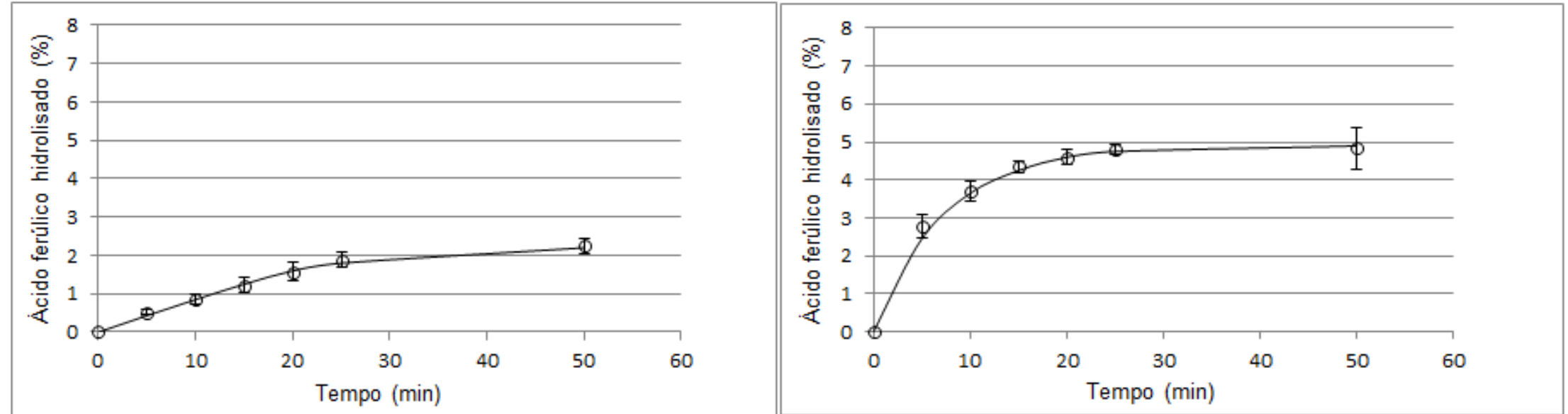

$\mathrm{C}$

$\mathrm{D}$
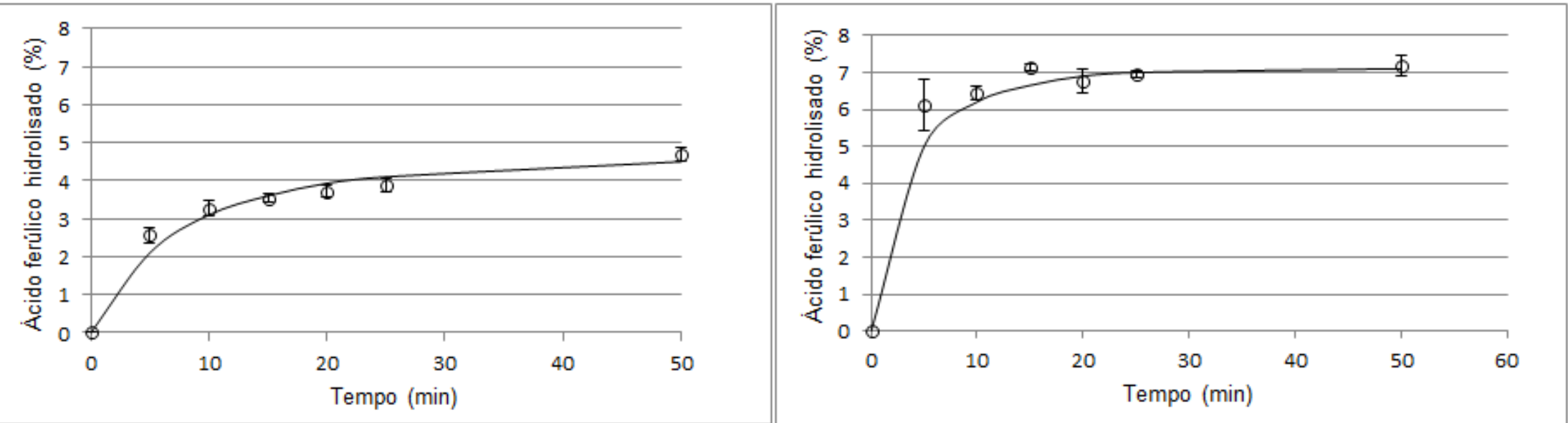
A partir desse conjunto de dados foi possível notar que a determinação da velocidade inicial de reação requer realizar o ensaio enzimático com baixas cargas enzimáticas nos quais o nível de conversão é baixo e, consequentemente, a reprodutibilidade da determinação da concentração de ácido ferúlico em solução será inevitavelmente baixa. Cabe enfatizar a metodologia experimental empregada até o momento em que a reação, realizada a $40^{\circ} \mathrm{C}$ é interrompida pelo rápido resfriamento em banho de gelo, seguido de centrifugação, amostragem e retorno à temperatura de reação. A amostragem realizada desta maneira e em curtos tempos de reação sujeita a variações experimentais de difícil controle. Com isso, optou-se por empregar um método para a determinação de atividade enzimática em que o tempo de reação foi fixado em 5 minutos e o nível de conversão alvo da reação seria de $2 \%$, assemelhando a metodologia daquela descrita para substratos celulósicos insolúveis, como os descritos por GHOSE (1987).

Considerando que a parada da reação em banho de gelo poderia estar sujeita a erros decorrentes de velocidades variáveis de resfriamento dependendo, por exemplo, das características do tubo empregado para conter o meio reacional (maior ou menor capacidade térmica, por exemplo), foram preliminarmente empregados outros métodos de parada da reação, conforme descrito a seguir.

\subsubsection{TESTES DE PARADA DE REAÇÃO COM AQUECIMENTO EM BANHO EM EBULIÇÃO OU POR ADIÇÃO DE ÁCIDO ACÉTICO AO MEIO REACIONAL}

Uma etapa de parada de reação empregando o aquecimento do meio reacional em banho em ebulição foi comparada com os resultados obtidos com a parada de reação em banho de gelo (Figura 25). Pode-se observar que, em diversos experimentos (com cargas crescentes de enzima no meio reacional), a quantidade de ácido ferúlico detectada foi sempre menor quando a parada da reação ocorria em banho em ebulição. De forma similar, um ensaio com uma única carga enzimática foi realizado seguido de parada da reação com a adição de ácido acético ao meio reacional (Tabela 12). Também neste caso se observou menor teor de ácido ferúlico quando ácido acético foi adicionado ao meio reacional. 
Figura 26- Comparação entre os métodos de parada de reação enzimática utilizando diferentes cargas de EFAE-RU ( 0,$01 ; 0,025 ; 0,05$ e $0,075 \mu \mathrm{g}$ de proteína/grama de substrato).

Condições de reação: Tampão citrato de sódio $50 \mathrm{mM}, \mathrm{pH} 6,3,40^{\circ} \mathrm{C}, 5$ minutos de reação.

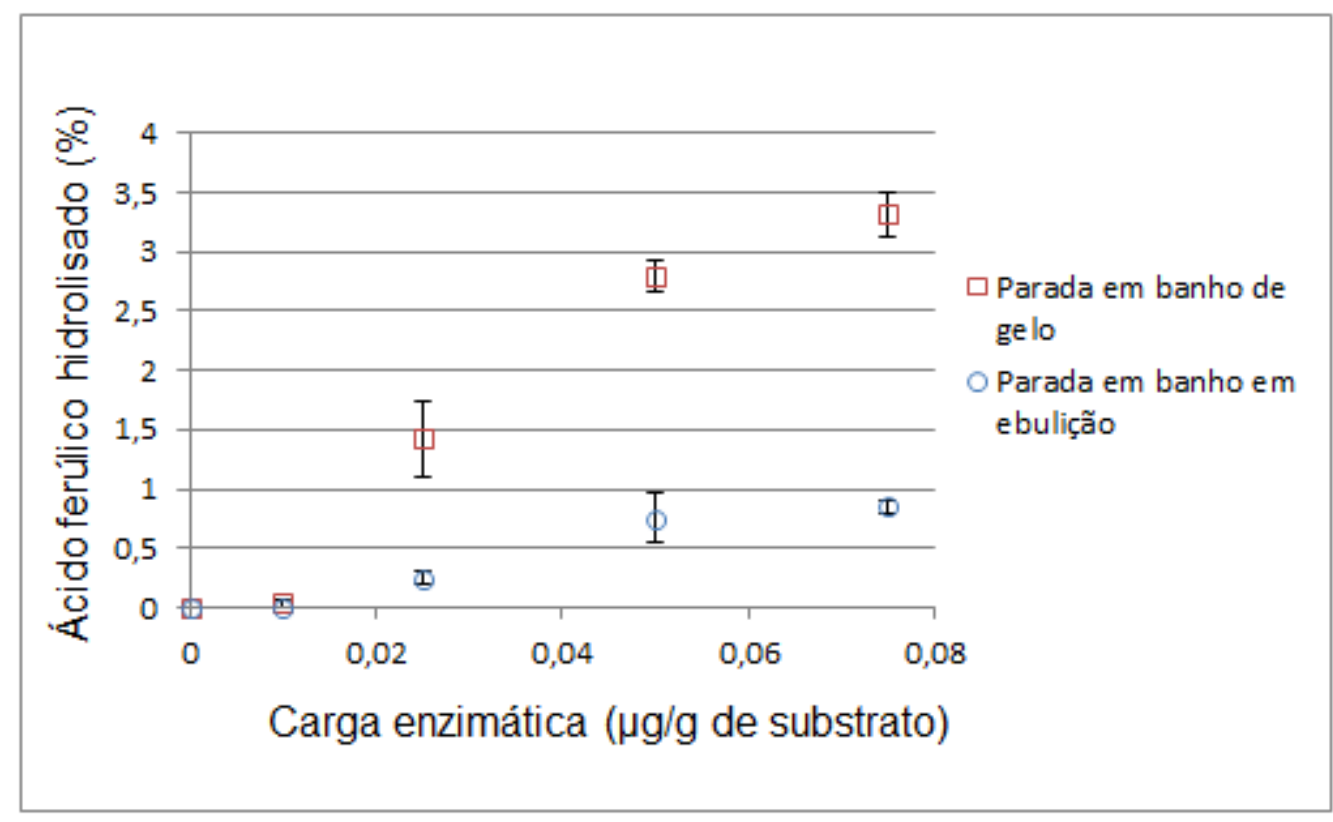

Tabela 12- Reação de 5 minutos usando EFAE-RU e substrato 89.

\begin{tabular}{cccc}
\hline Tratamento & $\begin{array}{c}\text { Carga enzimática } \\
\text { ( } \mu \text { de proteína/ grama de } \\
\text { substrato) }\end{array}$ & $\begin{array}{c}\text { \% ferúlico } \\
(\mathrm{mg} / \mathrm{mg} \text { éster total) }\end{array}$ & Desvio \\
\hline $\begin{array}{c}\text { Parada em gelo } \\
\text { Parada com ácido }\end{array}$ & 0,05 & 3,7 & 0,1 \\
acético & 0,05 & 0,8 & 0,3 \\
\hline
\end{tabular}

Haviam duas hipóteses possíveis para explicar os resultados obtidos (Figura 25 e Tabela 12): ou o banho com gelo não estava parando efetivamente a reação fazendo com que houvesse maior liberação do produto, levando a um resultado em que a conversão do éster estaria super estimada; ou o aquecimento e a adição de ácido acético interferiam de alguma forma na quantidade de ácido ferúlico detectável em solução. Para avaliar as possibilidades em questão, um experimento avaliou a estabilidade do ácido ferúlico (um padrão comercial preparado em concentrações conhecidas) frente à etapa de aquecimento em banho em ebulição e à etapa de mistura com ácido acético. Duas concentrações iniciais de ácido ferúlico foram tratadas de forma similar ao usado nos testes de parada de reação descritos anteriormente. Os dados obtidos estão mostrados na Figura 26. Constatou-se que tanto o tratamento térmico como o tratamento com 
ácido acético levou a uma diminuição na concentração de ácido ferúlico inicialmente presente em solução.

Figura 27- Solução padrão de ácido ferúlico em duas concentrações diferentes submetida à aquecimento e tratamento com ácido acético.

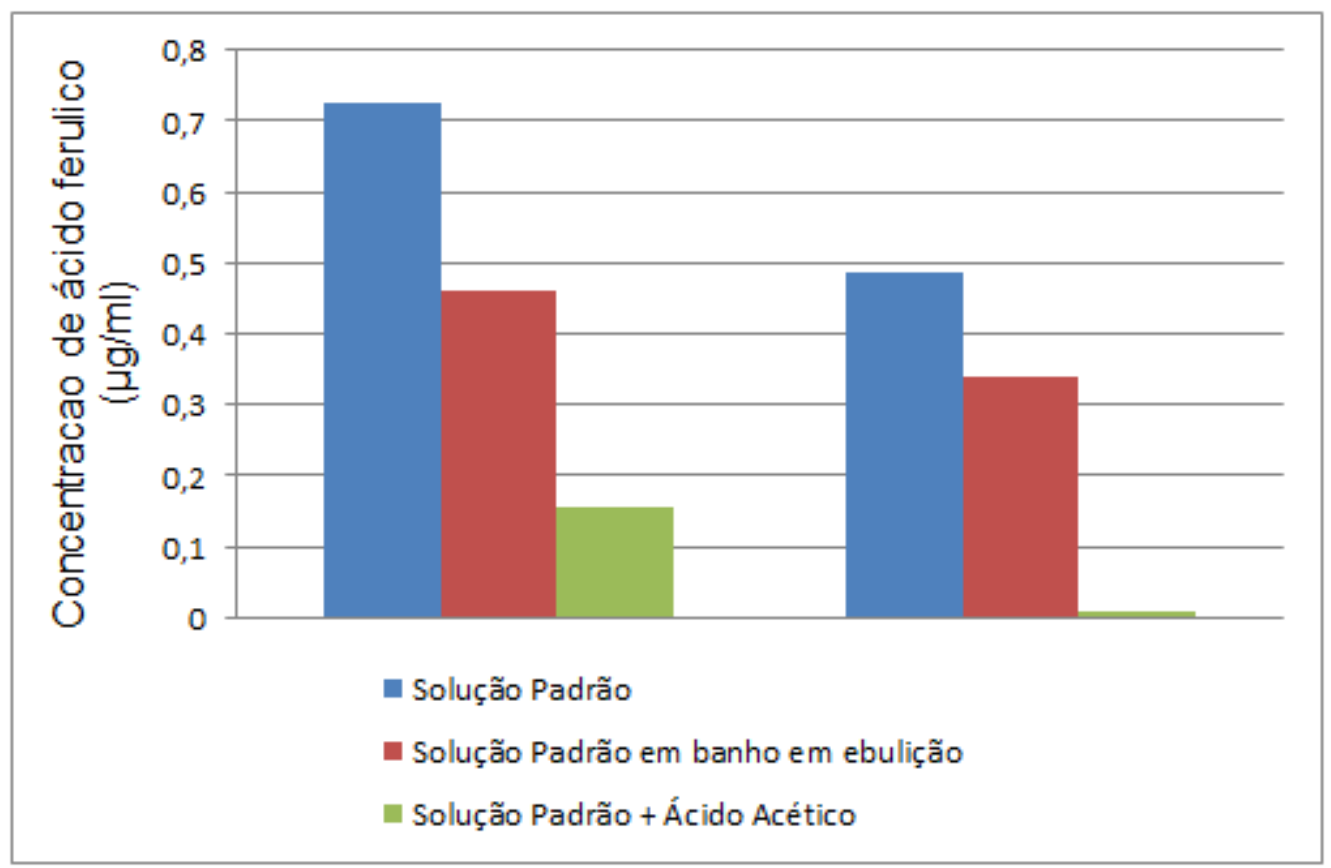

Os testes descritos demonstraram que nenhum dos métodos foi adequado para interromper a reação sem causar degradação do ácido ferúlico, uma vez que ambos os métodos levaram à sua diminuição de concentração. A partir desses dados ficou evidente que a melhor forma de parar a reação seria efetivamente 0 emprego de um banho de gelo, a fim de garantir que todo o ácido ferúlico liberado durante a reação enzimática fosse quantificado.

Alguns trabalhos anteriores avaliaram a estabilidade térmica do ácido ferúlico em solução. Réblová (2012) analisou o efeito da temperatura no poder antioxidante de diversos compostos fenólicos incluindo o ácido ferúlico e concluiu que o houve um decréscimo do poder antioxidante desses compostos com o aumento de temperatura e que o ácido ferúlico se tornou inativo a $150^{\circ} \mathrm{C}$. Concluiu também que apesar desse decréscimo de atividade ser comum, ele não é válido para todos os meios, visto que há estudos que demonstram que o aumento da temperatura pode aumentar a atividade antioxidante ou mantê-la constante. A partir desses estudos, pode-se perceber que pode haver 
decomposição térmica do ácido ferúlico e que possivelmente o banho de água fervente levou à sua oxidação ou adição de água à dupla ligação, impedindo a sua identificação por HPLC.

\subsection{ENSAIOS ENZIMÁTICOS}

Após todos os testes iniciais, foi definido que os ensaios enzimáticos se dariam a $40^{\circ} \mathrm{C}$ e $\mathrm{pH}$ 6,3 por 5 minutos. Ensaios preliminares (dados não mostrados) foram sempre realizados a fim de determinar as cargas de enzima necessárias para que se obtivesse cerca de $2 \%$ de hidrólise do ácido ferúlico presente no substrato nestas condições de reação. Idealmente, o método foi desenhado para gerar dados de conversão que fossem levemente inferiores à $2 \%$ de conversão, bem como dados de conversão levemente superiores a $2 \%$ de conversão, o que permitiria a determinação exata da carga de enzima necessária para converter $2 \%$ de éster do ácido ferúlico em ácido após 5 min de reação por interpolação de dados. Um exemplo de resultado experimental obtido está ilustrado na figura 27.

Analisando os resultados da Tabela 13 é possível perceber que, independente do substrato, a atividade de feruloil esterase foi maior na enzima EFAE-RU e menor na EFAEZCT. Não foi possível comparar os valores da atividade de FAEA em UI/ml uma vez que esta enzima estava na forma liofilizada e a atividade em $\mathrm{Ul} / \mathrm{mL}$ depende da concentração definida para a solução preparada.

Analisando a reprodutibilidade do método foi possível observar que no substrato RB a variação dos resultados foi maior, o que poderia ser explicado pela maior recalcitrância do substrato (maior quantidade de lignina e menor nível de digestão por ocasião do pré-tratamento da medula com celulases comerciais). A variação experimental empregando o substrato RB chegou a ser de $80 \%$ em relação à média quando foi avaliada a atividade da enzima EFAE-RU. No caso dos outros substratos, a variação experimental foi mais baixa. No substrato 58 , a variação experimental da atividade enzimática determinada foi de 7,5\% para EFAE-RU e de $8,9 \%$ para EFAEZCT. No substrato 89 as variações corresponderam a $37,6 \%$ e $17,8 \%$, respectivamente, para as mesmas enzimas. 
Uma conclusão decorrente da análise destes dados é que os substratos menos recalcitrantes (menos lignificados) são mais adequados para o método desenvolvido neste trabalho.

Ao analisar as atividades específicas das enzimas em estudo (Ul/ $\mathrm{\mu g}$ de proteína), percebe-se que a atividade de EFAE-RU continua sendo a maior, entretanto a atividade de FAEA é consideravelmente maior do que a atividade de EFAEZCT (Tabela 14).

Figura 28- Exemplificação de como a atividade da enzima EFAE-RU foi calculada. Gráfico em função da \% de ácido ferúlico liberado versus log da carga enzimática em $\mu \mathrm{g}$ de proteína/kg de substrato.

Condições de reação: Tampão citrato de sódio $50 \mathrm{mM}, \mathrm{pH}$ 6,3, $40^{\circ} \mathrm{C}, 5 \mathrm{~min}$ de reação. Substrato 58.

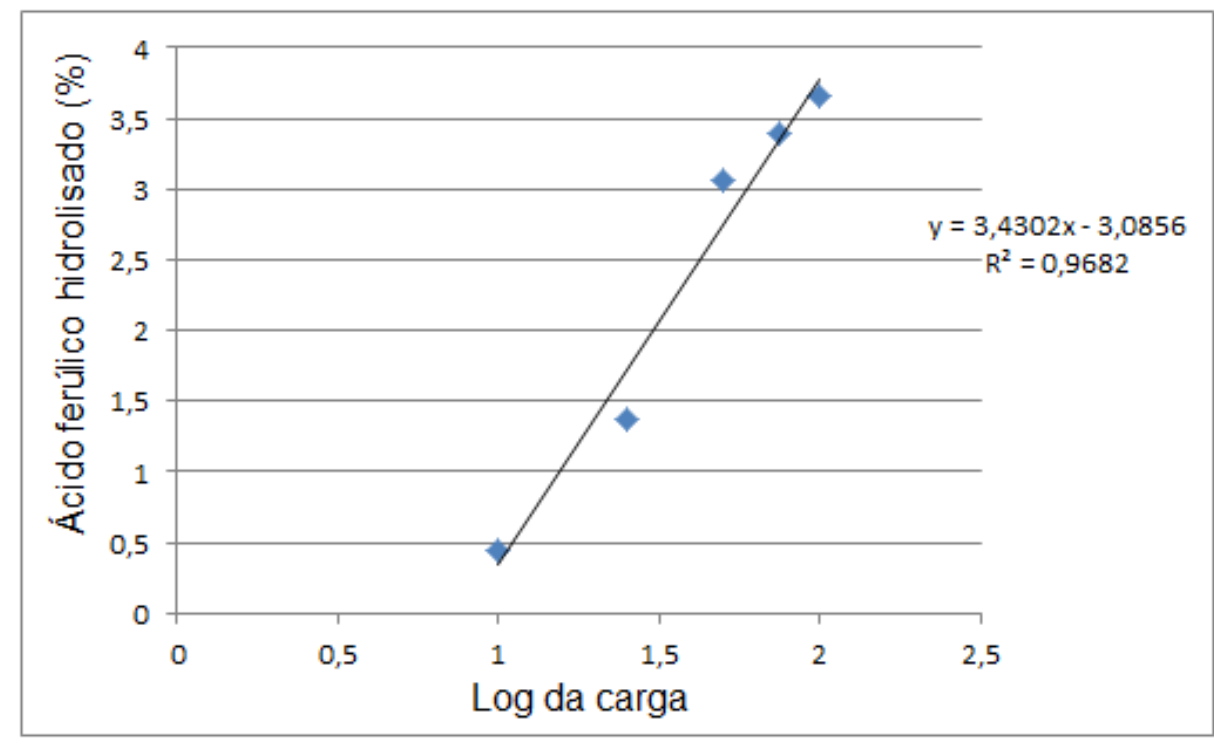

Tabela 13- Atividades de diferentes feruloil esterases ( $\mathrm{Ul} / \mathrm{ml})$ obtidas a partir de ensaios realizados com os substratos 58,89 e $\mathrm{RB}$.

\begin{tabular}{cccccc}
\hline \multicolumn{7}{c}{ ATIVIDADE NO SUBSTRATO 58 } \\
\hline Enzima & Atividade 1 & Atividade 2 & Atividade 3 & Média & Desvio \\
& $(\mathrm{Ul} / \mathrm{ml})$ & $(\mathrm{Ul} / \mathrm{ml})$ & $(\mathrm{Ul} / \mathrm{ml})$ & & \\
EFAE-RU & 1118,1 & 1220,4 & 1052,3 & 1130 & 85 \\
EFAEZCT & 27,2 & 27,3 & 31,6 & 29 & 3 \\
\hline \multicolumn{7}{c}{ ATIVIDADE NO SUBSTRATO 89 } \\
\hline Enzima & Atividade 1 & Atividade 2 & Atividade 3 & Média & Desvio \\
& $(\mathrm{Ul} / \mathrm{ml})$ & $(\mathrm{Ul} / \mathrm{ml})$ & $(\mathrm{Ul} / \mathrm{ml})$ & & \\
EFAE-RU & 1425,9 & 976,2 & 662,4 & 1021 & 384 \\
EFAEZCT & 20,7 & 29,5 & 24,6 & 25 & 4 \\
\hline \multicolumn{7}{c}{ ATIVIDADE NO SUBSTRATO RB } \\
Enzima & Atividade 1 & Atividade & Atividade 3 & Média & Desvio \\
EFAE-RU & $(\mathrm{Ul} / \mathrm{ml})$ & $(\mathrm{Ul} / \mathrm{ml})$ & $(\mathrm{Ul} / \mathrm{ml})$ & & \\
EFAEZCT & 582,1 & 282,3 & 82,7 & 316 & 251 \\
\hline
\end{tabular}


Tabela 14- Atividades específicas de diferentes feruloil esterases (UI/ $\mu \mathrm{g}$ de proteína) obtidas a partir de ensaios realizados com os substratos 58, 89 e RB.

\begin{tabular}{|c|c|c|c|c|c|}
\hline \multicolumn{6}{|c|}{ ATIVIDADE NO SUBSTRATO 58} \\
\hline Enzima & 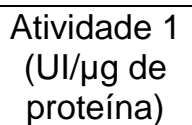 & 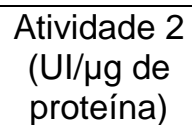 & 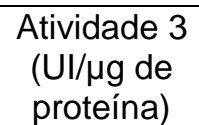 & Média & Desvio \\
\hline EFAE-RU & 2,2 & 2,4 & 2,1 & 2,3 & 0,2 \\
\hline FAEA & 0,11 & 0,20 & 0,17 & 0,16 & 0,05 \\
\hline EFAEZCT & 0,0062 & 0,0063 & 0,0073 & 0,0066 & 0,0006 \\
\hline \multicolumn{6}{|c|}{ ATIVIDADE NO SUBSTRATO 89} \\
\hline Enzima & 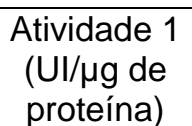 & $\begin{array}{l}\text { Atividade } 2 \\
\text { (Ul/ug de } \\
\text { proteína) }\end{array}$ & 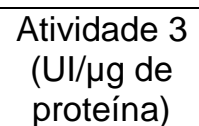 & Média & Desvio \\
\hline EFAE-RU & 2,9 & 2,0 & 1,3 & 2,0 & 0,8 \\
\hline FAEA & 0,32 & 0,28 & 0,31 & 0,30 & 0,02 \\
\hline EFAEZCT & 0,0048 & 0,0068 & 0,0056 & 0,006 & 0,001 \\
\hline \multicolumn{6}{|c|}{ ATIVIDADE NO SUBSTRATO RB } \\
\hline Enzima & $\begin{array}{c}\text { Atividade } 1 \\
\text { (Ul/ } / \mu \mathrm{g} \text { de } \\
\text { proteína) }\end{array}$ & 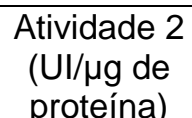 & 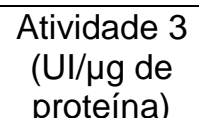 & Média & Desvio \\
\hline EFAE-RU & 1,2 & 0,6 & 0,2 & 0,6 & 0,5 \\
\hline FAEA & 0,5 & 0,2 & 0,4 & 0,4 & 0,1 \\
\hline EFAEZCT & 0,0043 & 0,0061 & 0,0065 & 0,006 & 0,001 \\
\hline
\end{tabular}

A Megazyme (fabricante das enzimas EFAE-RU e EFAEZCT), determinou as atividades específicas dessas mesmas enzimas quando utilizado etil ferulato como substrato. Para a enzima feruloil esterase de rúmen (EFAE-RU) o valor obtido foi de $79,7 \mathrm{U} / \mu \mathrm{g}$ de proteína e para a enzima de Clostridium thermocellum foi de $0,5 \mathrm{U} / \mu \mathrm{g}$ de proteína. Os valores fornecidos pela Megazyme® são bem superiores aos obtidos no trabalho, o que era esperado visto que o etil ferulato é um substrato sintético e não apresenta a complexidade do material lignocelulósico.

Para facilitar comparações entre as enzimas, as atividades específica obtidas foram graficadas conforme mostrado na Figura 28. Considerando que os dados seguem uma distribuição normal, a análise estatística dos mesmos pelo teste de Tukey (nível de significância de 5\%) indica que as atividades médias da enzima EFAE-RU não diferem quando os substratos 58 e 89 foram empregados no ensaio. No caso das enzimas feruloil esterase A (FAEA) e de Clostridium (EFAEZCT), não houve diferença estatística entre as atividades obtidas entre os três substratos.

A compilação dos dados da Figura 28 sugere que não só a recalcitrância dos substratos em estudo afeta o nível de atividade obtido, mas que também há 
certa especificidade das enzimas por alguns dos substratos. Neste sentido se destacam os dados da enzima EFAEZCT e FAEAque não variaram em função dos 3 diferentes substratos avaliados. Já a enzima EFAE-RU se mostrou menos ativa no substrato RB e o inverso foi observado para a enzima FAEA que mostrou menor afinidade pelo substrato 58 .

Figura 29- Atividades enzimáticas de três feruloil estereases expressas em UI/ $\mu \mathrm{g}$ de proteína determinadas a partir do emprego de diferentes substratos. A) Enzima EFAE-RU; B) Enzima FAEA; C) Enzima EFAEZCT.

A

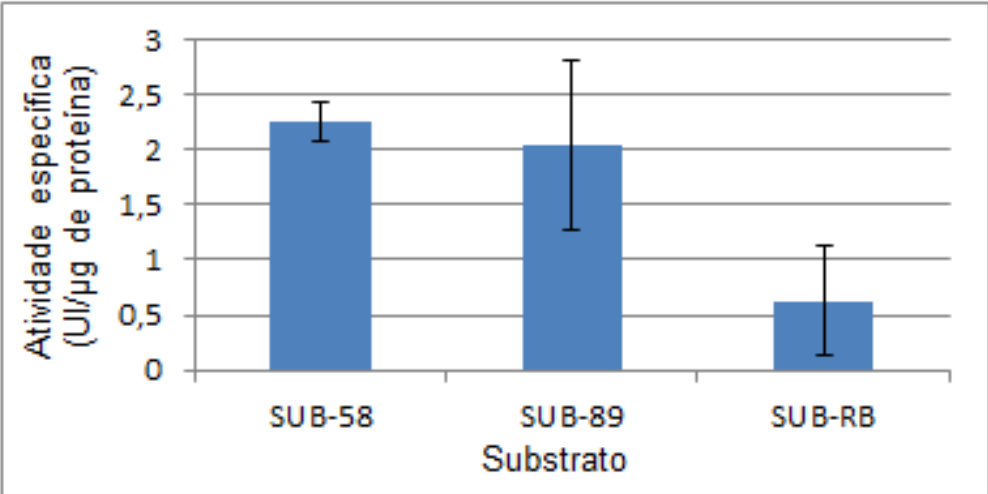

B

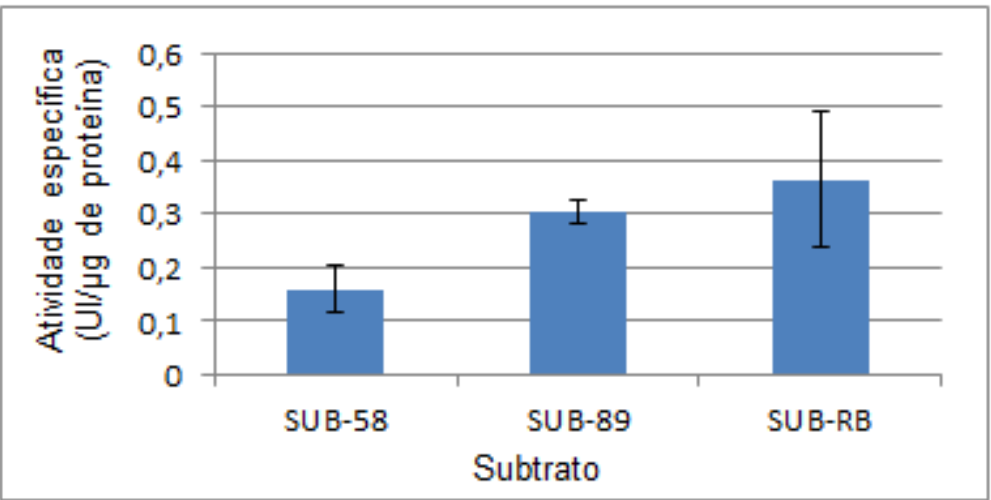

C

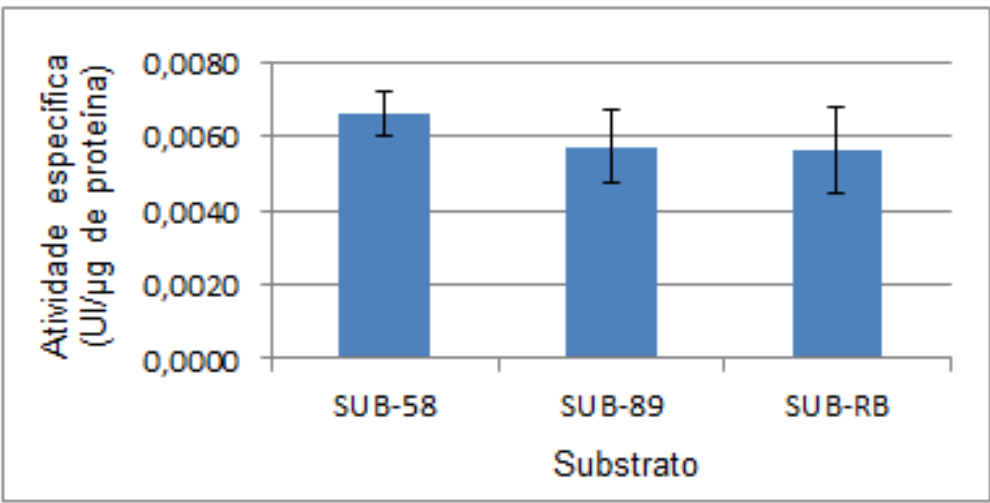




\subsection{EMPREGO DO MÉTODO DESENVOLVIDO PARA AVALIAR A INFLUÊNCIA DA TEMPERATURA E pH NA ATIVIDADE DAS ENZIMAS ESTUDADAS}

Para ilustrar a aplicabilidade do método desenvolvido em estudos de determinação da influência da temperatura na atividade enzimática foi realizado um ensaio com a enzima EFAE-RU e o substrato 58 em três temperaturas diferentes. Analisando os resultados (Figura 29) pode-se concluir que o método se mostrou sensível à variação de temperatura na etapa de determinação da atividade enzimática e que a temperatura mais adequada para a ação da enzima em questão foi de $40^{\circ} \mathrm{C}(1130 \mathrm{Ul} / \mathrm{ml})$. A temperatura de $25^{\circ} \mathrm{C}$ foi a que proporcionou a menor atividade $(63 \mathrm{Ul} / \mathrm{ml})$, menos do que a metade obtida a $60^{\circ} \mathrm{C}$, que foi de $220 \mathrm{UI} / \mathrm{ml}$. Uma vez que $40^{\circ} \mathrm{C}$ foi a melhor temperatura de atuação da enzima, os ensaios para analisar a influência do $\mathrm{pH}$ na atividade enzimática foram realizados nessa mesma temperatura.

Figura 30- Atividade de EFAE-RU em diferentes temperaturas de reação.

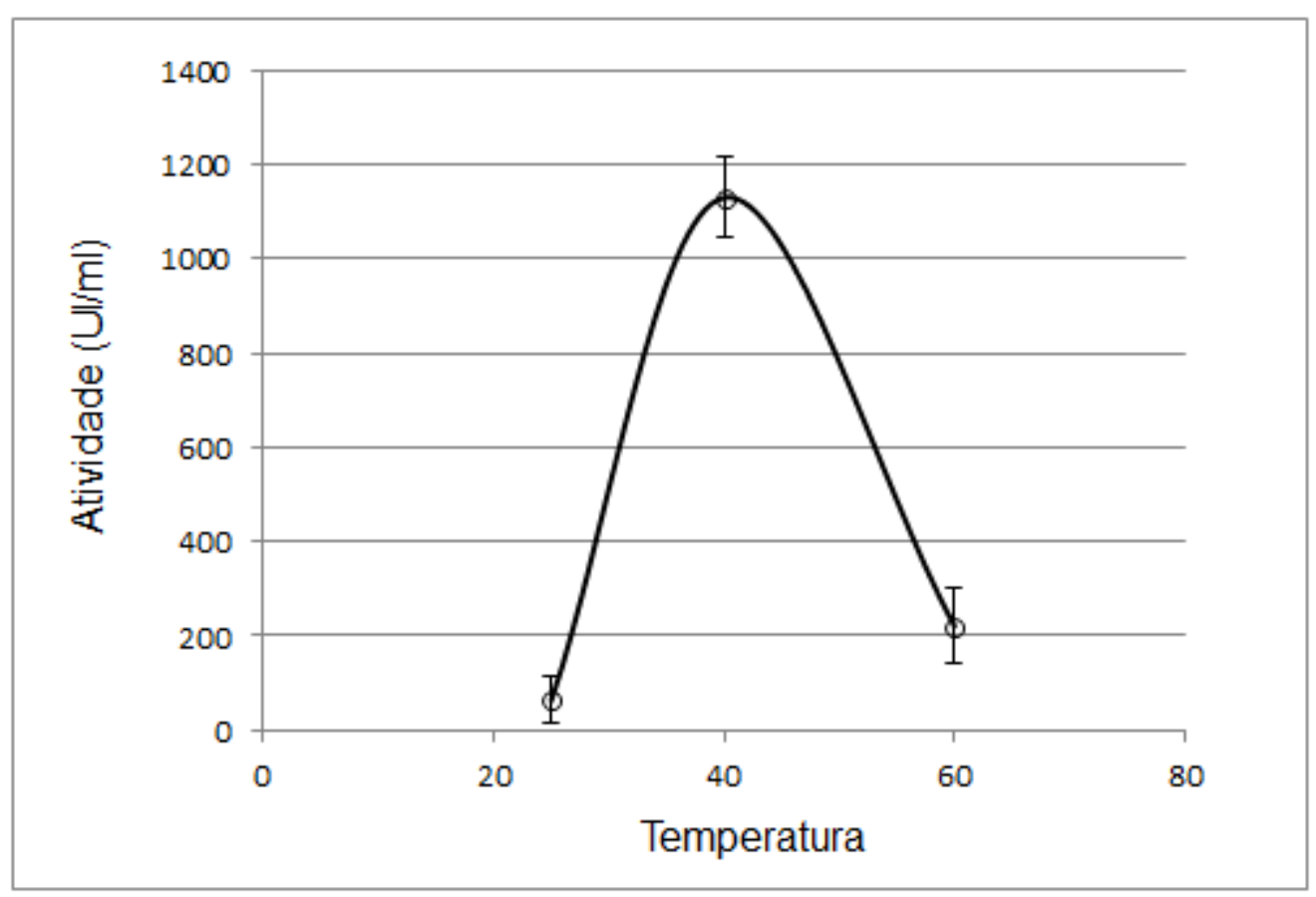


Nos ensaios de atividade das enzimas em diferentes pHs, os três diferentes substratos foram avaliados (Figura 30). Pode-se observar que em todos os ensaios a atividade de EFAE-RU foi maior nos pHs mais neutros $(6,3$ e 7,2$)$. Nos substratos 58 e 89 a atividade em pH 6,3 foi maior do que $1000 \mathrm{Ul} / \mathrm{ml}$, enquanto que no substrato RB só foi possível um valor próximo a esse em pH 7,2. No $\mathrm{pH}$ de 4,5 a atividade foi nula em todos os substratos e em pH 5,5 os valores foram muito baixos, principalmente no substrato RB que apresentou atividade de $4,3 \mathrm{UI} / \mathrm{ml}$. 

Figura 31- Atividade de EFAE-RU em diferentes pHs: 4,5; 5,5; 6,3 e 7,2 utilizando os substratos A)58, B) 89 e C) RB. A B

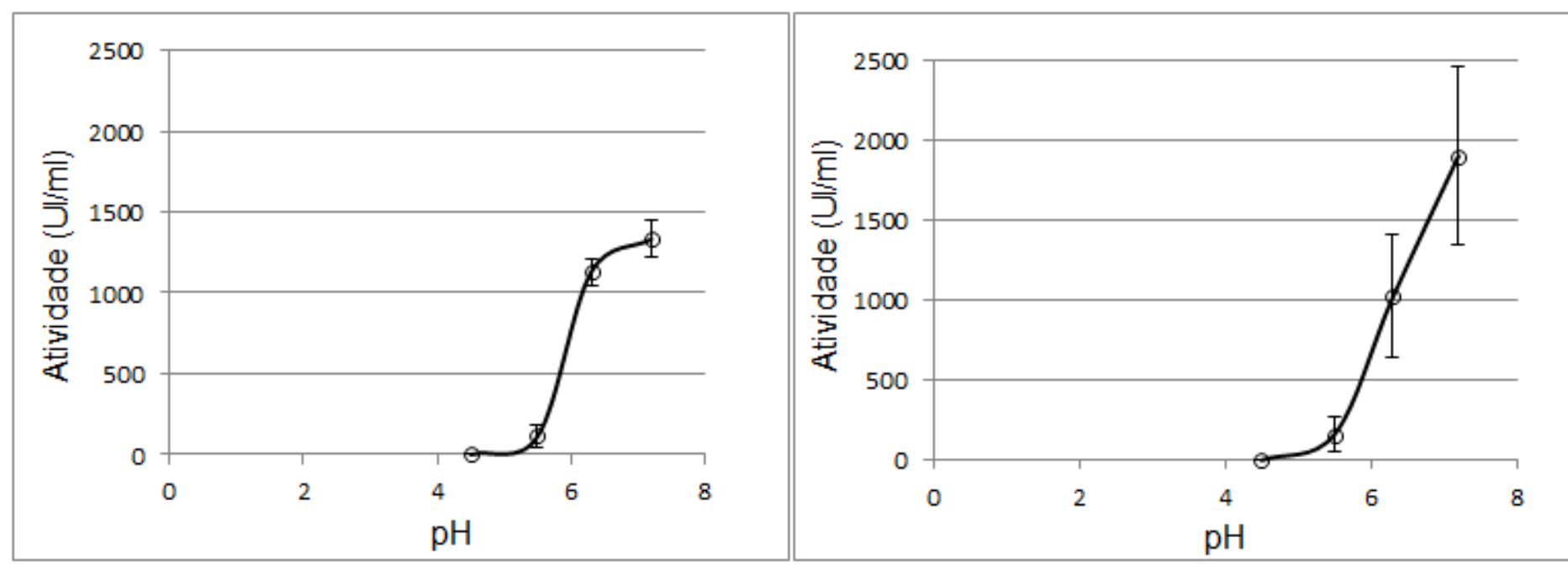

C

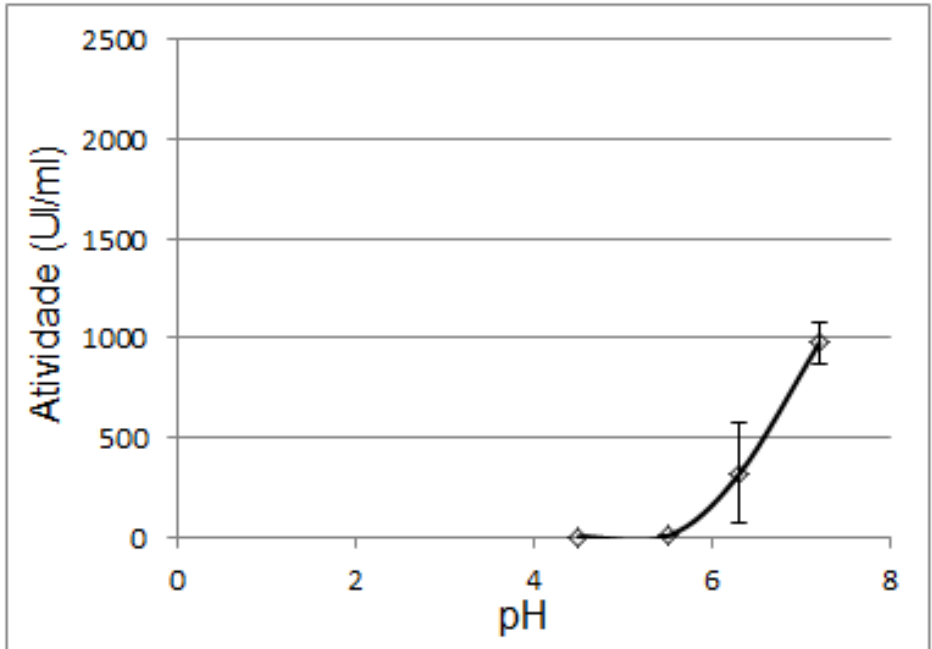




\section{CONCLUSÕES}

Este trabalho teve por finalidade o desenvolvimento de uma método para a determinação da atividade de feruloil esterases que fosse baseado no uso de um material lignocelulósico como substrato. Devido à dificuldade de degradação de materiais lignocelulósicos na matriz lignificada, foi escolhido um material de baixa recalcitrância que é encontrado na região da medula de entrenós de cana-deaçúcar. Este material foi pré-tratado por digestão com celulase para facilitar ainda mais a acessibilidade das feruloil esterases à cadeis esterificadas de hemicelulose. Foram usados dois híbridos de baixo teor de lignina (58 e 89) e um cultivar de referência (RB). Várias hidrólises foram realizadas com diferentes cargas enzimáticas em diferentes condições para o desenvolvimento de um método apropriado. Os dados obtidos indicaram que não seria adequado medir a atividade a partir da tangente dos pontos iniciais da conversão enzimática, uma vez que o tempo de reação seria curto demais para determinar a velocidade máxima (5 minutos) e que nesta situação havia uma elevada variação experimental decorrente do método de amostragem empregado e do baixo nível de conversão dos ésteres em ácido. Desta forma, optou-se por avaliar a atividade a partir da preparação de diluições sucessivas da enzima e um tempo de reação fixado em 5 minutos. Neste tempo de reação foi verificado que as conversões de éster em ácido deveriam estar idealmente entre 1 e $2 \%$ e que assim seria possível determinar a atividade enzimática na região da cinética onde a velocidade de reação era máxima.

Após o desenvolvimento de um método apropriado para a determinação da atividade enzimática foram feitas as reações para determinar a atividade das enzimas feruloil esterase de rúmen ( EFAE-RU), feruloil esterase A (FAEA) e feruloil esterase de Clostridium thermocellum (FAEZCT). As atividades foram de $1130 \pm 85 \mathrm{Ul} / \mathrm{ml}$ para EFAE-RU e menor para EFAEZCT. Analisando as atividade específicas (UI/ $\mu \mathrm{g}$ de proteína), a atividade de FAEA foi consideravelmente maior do que a atividade de EFAEZCT.

O método desenvolvido apresentou maior reprodutibilidade quando são usados substratos com menor teor de lignina, no caso os híbridos 58 e 89 . No 
substrato de referência $(\mathrm{RB})$, houve até $80 \%$ de variação da média dos resultados. Apesar de o método ter se mostrado mais eficiente com os substratos menos lignificados, a atividade de cada enzima não dependeu especificamente de cada substrato. A enzima EFAE-RU se mostrou mais eficiente nos substratos $58 \mathrm{e}$ 89 e com o RB a atividade foi menor, indicando que a enzima atua melhor em substratos com teor baixo de lignina. Entretanto, com as enzimas FAEA e EFAEZCT, não houve diferença significativa entre as atividades obtidas entre os três substratos utilizados.

Ao avaliar o efeito da temperatura e do $\mathrm{pH}$ sobre a atividade da enzima EFAE-RU, percebeu-se que a melhor temperatura para as reações é de $40^{\circ} \mathrm{C}$ e que os pHs 6,3 e 7,2 levaram a atividades maiores, enquanto que as atividade foram nulas ou muito baixas nos pHs 4,5 e 5,5 respectivamente.

O presente trabalho levou à elaboração de uma metodologia para a determinação de feruloil esterases a partir do uso de um material lignocelulósico como substrato. Apesar do método ter apresentado algumas oscilações na determinação da atividade, o que já era esperado devido ao curto tempo de reação para determinar a velocidade máxima, ele poderá ser utilizado para a determinação não só das feruloil esterases, mas potencialmente servirá também para determinar a atividade de outras esterases como as acetil esterases, nas quais as atividades ainda são determinadas a partir de métodos que empregam substrato sintéticos. 


\section{REFRÊNCIAS BIBLIOGRÁFICAS}

ARANTES, V.; MILAGRES, A. M. Relevância de compostos de baixa massa molar produzidos por fungos e envolvidos na biodegradação da madeira. Química Nova, v.32. n.6, p.1586-1595, 2009.

BENOIT, I.; NAVARRO, D.; MARNET, N.; RAKOTOMANOMANA, N.; LESAGE-MEESSEN, L.; SIGOILLOT, J.-C.; ASTHER, M.; ASTHER,M. Feruloyl esterases as a tool for the release of phenolic compounds from agroindustrial by-products. Carbohydrate Research, v.341, p.1820-1827, 2006.

BIELY, P. Microbial carbohydrate esterases deacetylating plant polysaccharides. Biotechnology advances, v.30, p. 1575-88, 2012.

BIELY, P.; PULS, J.; SCHNEIDER, H. Acetyl xylan esterases in fungal cellulolytic systems. FEBS Letters, v.186, n.1, p.80-84, 1985.

BORNEMAN, W. S.; HARTLEY, R. D.; MORRISON, W. H.; AKIN, D. E.; LJUNGDAHL, L. G. Applied microbiology biotechnology feruloyl and $p$ coumaroyl esterase from anaerobic fungi in relation to plant cell wall degradation. Applied Microbiology and Biotechnology, v.33, p.345-351, 1990.

BOUDET, A.-M. Evolution and current status of research in phenolic compounds. Phytochemistry,v. 68, p. 2722-2735, 2007.

CAI, Y.; LI, G.; NIE, J.; LIN, Y.; NIE, F.; ZHANG, J.; XU, Y. Study of the structure and biosynthetic pathway of lignin in stone cells of pear. Scientia Horticulturae, v.125, p.374-379, 2010.

CHAHINIAN, H.; SARDA, L. Distinction between esterases and lipases: comparative biochemical properties of sequence-related carboxylesterases. Protein and peptide Letters, v.16, p. 1149-1161, 2009. 
COSTA, T. H. F.; MASSARIN F.; BONIFACIO, T. O.; MILAGRES, A. M. F.; FERRAZ, A. The enzymatic recalcitrance of internodes of sugar cane hybrids with contrasting lignin contents. Industrial Crops and Products, v. 51, p. 202-211, 2013.

DONAGHY, J.; MCKAY, A. M. Purification and characterization of a feruloyl esterase from the fungus Penicillium expansum. Journal of Applied Microbiology, v.83, p.718-726, 1997.

ENGEL, P. C.; HAMES, B. D.; RICKWOOD, D. Enzymology Labfax, : Dublin: Academic Press 1996. Cap.3.

FAULDS, B.; WILLIAMSON, G. The purification and characterization of 4hydroxy-3-methoxycinnamic ( ferulic) acid esterase from Streptomyces olitrochromogenes. Journal of General Microbiology, v. 137, p. 2339-2345, 1991.

FAULDS, C. B.; SANCHO, A. L.; BARTOLOMÉ, B. Mono- and dimeric ferulic acid release from brewer's spent grain by fungal feruloyl esterases. Applied Microbiology and Biotechnology, v. 60, p. 489-494, 2002.

FAULDS, CRAIG B. What can feruloyl esterases do for us? Phytochemistry Reviews, v. 9, p. 121-132, 2010.

FAULDS, C. B.; WILLIAMSON, G. Purification and characterization of a ferulic acid esterase (FAEIII) from Aspergillus niger: specificity for the phenolic moiety and binding to microcrystal line cellulose. Microbiology, v. 140, p. 779-787, 1994.

FAZARY, A. E.; JU, Y. Feruloyl Esterases as Biotechnological Tools: Current and Future Perspectives. Acta Biochimica et Biophysica Sinica, v. 39 n.11, p. 811-828, 2007.

FENGEL, D.; WEGENER, G. Wood chemistry, ultrastructure and reactions. Berlin; Walter de Gruyter, 1989. 
FERRAZ, A.; BAEZA, J.; RODRIGUEZ, J.; FREER, J. Estimating the chemical composition of biodegraded pine and eucalyptus wood by DRIFT spectroscopy and multivariate analysis. Bioresource Technol, v.74, p.201$212,2000$.

FERRAZ, A. Fungos decompositores de materiais lignocelulósicos, In: ESPOSITO, E.; AZEVEDO, J. L. Ed. Fungos: uma introdução à biologia, bioquímica e biotecnologia. Caxias do Sul: Educs, cap.6. p. 215-242, 2004.

FIDDLER, W.; PARKER, W.; WASSERMAN, A.; DOERR, R. Thermal Decomposition of ferulic acid. Journal of Agricultural and Food Chemistry, v.15, n.5, p. 757-761,1967.

GíRIO, F. M.; FONSECA, C.; CARVALHEIRO, F.; DUARTE, L. C.; MARQUES, S.; BOGEL-LUKASIK, R. Hemicelluloses for fuel ethanol: A review. Bioresource Technology, v. 101, p. 4775-4800, 2010.

GRABBER, J. H.; RALPH, J.; \& HATFIELD, R. D. Cross-linking of maize walls by ferulate dimerization and incorporation into lignin. Journal of Agricultural and Food Chemistry, v. 48, p. 6106-6113, 2000.

HAYASHI, T; KAIDA, R. Hemicelluloses as recalcitrant components for saccharification in wood cap.4. In: GELLERSTEDT, G.; EK, M.; HENRIKSSON, G. Ed. Pulp and paper chemistry and technology. São Paulo: De Gruyter 2011. Cap 4, p. 45-52.

HEGDE, S., SRINIVAS, P., \& MURALIKRISHNA, G. Single-step synthesis of 4-nitrophenyl ferulate for spectrophotometric assay of feruloyl esterases. Analytical Biochemistry, v. 387, p. 128-129, 2009.

HEMSWORTH, G. R.; DAVIES, G. D.; WALTON, P. H. Recent insights into copper-containing lytic polysaccharide mono-oxygenases. Current Opinion in Structural Biology, v.23, p:660-668, 2013. 
HENRIKSSON, G., Lignin, cap.6. In: EK, M. GELLERSTEDT, G; HENRIKSSON, G. ed. Pulp and Paper Chemistry and Technology, Weinheim, Germany: De Gruyter 2009. V.1. Cap. 6. p. 121-145.

HORN, S.; VAAJE-KOLSTAD, G.; WESTERENG, B.; EIJSINK, V. Novel enzymes for the degradation of cellulose. Biotechnology for biofuels, v.5, $p$. 45, 2012.

liYAMA K.; LAM T. B. T.; STONE B. A., Phenolic acid bridges between polysaccharides and lignin in wheat intemodes. Phytochemistry v. 29, p. 733-737, 1990.

JACOBSEN, S. E.; WYMAN, C. E. Cellulose and hemicellulose hydrolysis models for application to current and novel pretreatment processes. Applied Biochemistry And Biotechnology, v. 84-86, p. 81-96, 2000.

KLEMM, D.; PHILIPP, B.; HEINZE, T.; HEINZE, U.; WAGENKNECHT, W. Comprehensive cellulose chemistry: fundamentals and analytical methods v.1, p. 1-286, 1998.

KORMELINK, F.J.M.; LEFEBVRE, B.; STROZYK, F.; VORAGEN, A.G.J., Purification and characterization of an acetyl xylan esterase from Aspergillus niger. Journal of Biotechnology, v.27, p.267-282, 1993.

KOSEKI, T.; MIWA, Y.; AKAO, T.; AKITA, O.; HASHIZUME, K. An Aspergillus oryzae acetyl xylan esterase: molecular cloning and characteristics of recombinant enzyme expressed in Pichia pastoris. Journal of Biotechnology, v. 121, p. 381-389, 2006.

LAM, T. B.; KADOYA, K.; IIYAMA, K. Bonding of hydroxycinnamic acids to lignin: ferulic and $p$-coumaric acids are predominantly linked at the benzyl position of lignin, not the beta-position, in grass cell walls. Phytochemistry, v. 57, p. 987-992, 2001.

LAM, T. B.; STONE, B. A. Covalent Cross-Links in the Cell Wall. Plant Physiology, v. 104, p. 315-320, 1994. 
LEVASSEUR, A.; DRULA, E.; LOMBARD, V.; COUTINHO, P. M.; HENRISSAT, B. Expansion of the enzymatic repertoire of the CAZy database to integrate auxiliary redox enzymes. Biotechnology for Biofuels, v. 6, p. 41, 2013.

LI, M.; FOSTER, C.; KELKAR, S.; PU, Y.; HOLMES, D.; RAGAUSKAS, A.; SAFFRON, C. M.; HODGE, D. B. Structural characterization of alkaline hydrogen peroxide pretreated grasses exhibiting diverse lignin phenotypes. Biotechnology for biofuels, v. 5, p. 38, 2012.

LIU, K.; YAN, L.; YAO, G.; GUO, X. Estimation of p-coumaric acid as metabolite of E-6-O-p-coumaroyl scandoside methyl ester in rat plasma by HPLC and its application to a pharmacokinetic study. Journal Of Chromatography $B$ analytical technologies in the Biomedical and Life Sciences, v. 831, p. 303-306, 2006.

MASARIN, F.; GURPILHARES, D. B.; BAFFA, D. C.; BARBOSA, M. H. P.; CARVALHO, W.; FERRAZ, A.; MILAGRES, A. M. F. Chemical composition and enzymatic digestibility of sugarcane clones selected for varied lignin contents. Biotechnology for biofuels, v. 4, p. 1-10, 2011.

MCCALLUM, J. A.; TAYLOR, I. E.; TOWERS, G. N. Spectrophotometric assay and electrophoretic detection of trans-feruloyl esterase activity. Analytical Biochemistry, v. 196, p.360-366, 1991.

MENDES, F. M.; SIQUEIRA, G.; CARVALHO, W.; FERRAZ, A.; MILAGRES, A. M. F. Enzymatic hydrolysis of chemithermomecanically pretreated sugarcane Bagasse and two experimental samples with reduced initial lignin content. Biotechnol Progr, v.27, p.395-401, 2011.

MOHAN, D.; PITTMAN, C. U.; STEELE, P. H. Single, binary and multicomponent adsorption of copper and cadmium from aqueous solutions on Kraft lignin - a biosorbent. Journal of Colloid and Interface Science, v. 297, p. 489-504, 2006. 
MOREIRA, L. R. S.; MILANEZI, N. G; FILHO, E. X. F. Enzymology of plant cell wall breakdown: an update. In: BUCKERIDGE, M.S; GOLDMAN, G.H ed. Routes to cellulosic ethanol, Brasília: Springer 2011. Cap 6. p. 73-96.

NELSON, D. L.; COX, M. M. Princípios de Bioquímica de Lehninger. 5.ed. Porto Alegre: Artmed, 2011.

PANAGIOTOU, G.; OLAVARRIA, R.; OLSSON, L. Penicillium brasilianum as an enzyme factory; the essential role of feruloyl esterases for the hydrolysis of the plant cell wall. Journal of Biotechnology, v. 130, p. 219-228, 2007.

PANDA, T.; GOWRISHANKAR, B. S. Production and applications of esterases. Applied microbiology and biotechnology, v. 67, p. 160-169, 2005.

PÉREZ, J.; MUNOZ-DORADO, J.; DE LA RUBIA, T.; MRTíNEZ, J. Biodegradation and biological treatments of cellulose hemicellulose and lignin: an overview. International Microbiology, v. 5, p.53-63, 2002.

PESSOTI, D. Dissertação Dayelle Sâmila Pessoti de Oliveira Gonçalves. Estudo sobre o modo de ação de enzimas hidrolíticas produzidas por fungos degradadores de madeira sobre substratos com elevado teor de lignina. 2013.

POLIZELI, M L.T.M.; CORRÊA, E C.P.; POLIZELI, A M; JORGE, J A. Hydrolases from microorganisms used for degradation of plant cell wall and bioenergy. In: BUCKERIDGE, M.S; GOLDMAN, G.H ed. Routes to cellulosic ethanol. Brasília: Springer, 2011. Cap 8. p. 115-134.

POUVREAU, L.; JONATHAN, M. C.; KABEL, M. A.; HINZ, S. W. A.; GRUPPEN, H.; SCHOLS, H. A. Characterization and mode of action of two acetyl xylan esterases from Chrysosporium lucknowense $\mathrm{C} 1$ active towards acetylated xylans. Enzyme and microbial technology, v. 49, p. 312-20, 2011. 
RALET, M. C.; FAULDS, C. B.; WILLIAMSON, G.; THIBAULT, J. F. Degradation of feruloylated oligosaccharides from sugar-beet pulp and wheat bran by ferulic acid esterases from Aspergillus niger. Carbohydrate Research, v. 263, p. 257-269, 1994.

RALPH, J.; HATFIELD, R. D; QUIDEAU, S.; HELM, R. F.; GRABBER, J. H.; HANS-JOACHIM, G. J. Pathway of p-coumaric acid incorporation into maize lignin as revealed by NMR. Journal of the American Chemical Society, $v$. 116, p. 9448-9456, 1994.

ROSAZZA, J.; HUANG, Z.; DOSTAL, L.; VOLM, T.; ROUSSEAU, B. Review: Biocatalytic transformations of ferulic acid: an abundant aromatic natural product. Journal of Industrial Microbiology, v.15, p. 457-471, 1995.

SABERIKHAH, E.; MOHAMMADI-ROVSHANDEH, J.; MAMAGHANI, M. Spectroscopic comparison of organsolv lignins isolated from wheat straw. Cellulose Chemistry and Technology, v. 47, p. 409-418, 2013.

SAHA, B. C. Hemicellulose bioconversion. Journal of Industrial Microbiology Biotechnology, v. 30, p. 279-291, 2003a.

SAHA, B. C. Hemicellulose bioconversion. Journal of Industrial Microbiology Biotechnology, v. 30, p. 279-291, 2003b.

SCALBERT A.; MONTIES B.; LALLEMAND J-Y; GUITTET E.; ROLANDO C. Ether linkage between phenolic acids and lignin fractions from wheat straw. Phytochemistry, v. 24, p.1359-1362, 1985.

SCALBERT A.; MONTIES B.; ROLANDO C.; SIERRA-ESCUDERO A. Formation of ether linkage between phenolic acids and Gramineae lignin: a possible mechanism involving quinone methides. Holz- forschung v. 40, p. 191-195, 1986.

SCHELLER, H. V.; ULVSKOV, P. Hemicelluloses. Annual review of plant biology, v. 61, p. 263-289, 2010. 
SHAO, W.; WIEGEL, J. Purification and characterization of two thermostable acetyl xylan esterases from Thermoanaerobacterium sp. strain JW/SL-YS485. Applied and Environmental Microbiology, v. 61 n.2, p. 729-733, 1995.

SHIMADA, M.; FUKUZUKA, T.; HIGUCHI, T. Ester linkages of $p$-coumaric acid in bamboo and grass lignins. TAPPI, v. 54, p. 72-78, 1971.

SINGH, A.; MISHRA, P. Microbial pentose utilization: current applications in biotechnology. Amsterdam: Elsevier Science B. V., 1995. v. 33. p. 33-70.

SIQUEIRA, G.; MILAGRES, A. M.; CARVALHO, W.; KOCH, G.; FERRAZ, A. Topochemical distribution of lignin and hydroxycinnamic acids in sugar-cane cell walls and its correlation with the enzymatic hydrolysis of polysaccharides. Biotechnology for biofuels, v. 4:7, p. 1-9., 2011.

TEERI, T.; HENRIKSSON, G. Enzymes degrading wood components. In: EK, M.; GELLERSTEDT, G; HENRIKSSON, G. ed. Pulp and paper chemistry and technology. Weinheim: De Gruyter, 2009. Cap. 11. p. 245-270.

TELEMAN, A., Hemicelluloses and Pectins. In: EK, M.; GELLERSTEDT, G.; HENRIKSSON, G. ed. Pulp and paper chemistry and technology, Weinheim: De Gruyter, 2009. v. 1. Cap. 5. p. 102-120.

YANG, H. J.; YUE, Q.; CAO, Y. C.; ZHANG, D. F.; WANG, J. Q. Effects of crude feruloyl and acetyl esterase solutions of Neocallimastix sp. YQ1 and Anaeromyces sp. YQ3 isolated from Holstein steers on hydrolysis of Chinese wildrye grass hay, wheat bran, maize bran, wheat straw and corn stalks. Animal Feed Science and Technology, v. 154, p. 218-227, 2009.

ZENG, M.; XIMENES, E.; LADISCH, M. R.; MOSIER, N. S. Tissue-specific biomass recalcitrance in corn stover pretreated with liquid hot-water: enzymatic hydrolysis (Part 1). Biotechnology and Bioengineering. v. 109, n.2, p 390-397, 2011. 
ZIFCAKOVA, L.; BALDRIAN, P. Fungal polysaccharide monooxygenases: new players in the decomposition of cellulose. Fungal Ecology, v. 5, p.481489, 2012.

ZUZANA RÉBLOVÁ. Effect of temperature on the antioxidant activity of phenolic acids. Czech Journal of Food Sciences, v.30, n. 2 p. 171-177, 2012. 